\title{
Forest songbird abundance and viability at multiple scales on the Monongahela National Forest, West Virginia
}

\author{
Thomas Eugene DeMeo \\ West Virginia University
}

Follow this and additional works at: https://researchrepository.wvu.edu/etd

\section{Recommended Citation}

DeMeo, Thomas Eugene, "Forest songbird abundance and viability at multiple scales on the Monongahela National Forest, West Virginia" (1999). Graduate Theses, Dissertations, and Problem Reports. 1045.

https://researchrepository.wvu.edu/etd/1045

This Dissertation is protected by copyright and/or related rights. It has been brought to you by the The Research Repository @ WVU with permission from the rights-holder(s). You are free to use this Dissertation in any way that is permitted by the copyright and related rights legislation that applies to your use. For other uses you must obtain permission from the rights-holder(s) directly, unless additional rights are indicated by a Creative Commons license in the record and/ or on the work itself. This Dissertation has been accepted for inclusion in WVU Graduate Theses, Dissertations, and Problem Reports collection by an authorized administrator of The Research Repository @ WVU.

For more information, please contact researchrepository@mail.wvu.edu. 


\title{
FOREST SONGBIRD ABUNDANCE AND VIABILITY \\ AT MULTIPLE SCALES \\ ON THE MONONGAHELA NATIONAL FOREST, WEST VIRGINIA
}

\author{
Thomas Eugene DeMeo
}

\author{
Dissertation \\ Submitted to the Graduate Faculty of the \\ College of Agriculture and Forestry \\ West Virginia University \\ In Partial Fulfillment of the Requirements for \\ The Degree of Doctor of Philosophy \\ in Forest Resources Science
}

Petra B. Wood, Chair

Gregory Elmes

Linda Gribko

Rosemarie Muzika

Charles Yuill

Morgantown, West Virginia

1999

Keywords: Neotropical migrants, forest fragmentation, landscape ecology, multiple scales, nest survival, bird-habitat relationships 


\section{ABSTRACT \\ Forest Songbird Abundance and Viability at Multiple Scales on the Monongahela National Forest, West Virginia}

Thomas Eugene DeMeo

Songbird-habitat relationships were investigated using three interrelated studies, each at multiple scales, on the Monongahela National Forest, West Virginia. In each study I used landscape $(25 \mathrm{~km} 2)$, transect $(2500 \mathrm{~m})$, and point (50-m radius point count plot) scales.

In the first study, I investigated bird abundance and species richness at these scales in four major forest types: mixed mesophytic, northern hardwoods, red spruce, and dry oaks. At the landscape scale, forest types differed in bird abundance $(p=0.07)$ and species richness $(\mathrm{p}=0.08)$. Abundance of forest-interior species, Neotropical migrants, and nine key indicator species were greatest in the mixed mesophytic $(\mathrm{p}<0.05)$. Bird abundance and species richness differences at the transect scale were significant $(\mathrm{p}<0.001)$ and were related to differences in stand height and canopy structure.

Relatively little variation in bird abundance or richness occurred between points within a transect, even though transects were oriented to capture the maximum variation in elevation. Environmental variables explained much more variation at the transect than at the local scale.

The second study compared bird abundance (through point counts) and viability (through nest search survival data) across mixed mesophytic landscapes ranging from $42 \%$ to $81 \%$ forest core area. Nest search plots were long and narrow (200 m by 2000 $\mathrm{m})$, and superimposed over point count transects. Forested core area and edge density showed little relationship to bird abundance or viability at landscape or transect/plot scales. A distinct edge effect was found up to $25 \mathrm{~m}$ from edges; at greater distances the relationship of nest survival to distance from edge was ambiguous. Nest survival was greater at edges of regenerating clearcuts than along roads, possibly because of greater concealment.

In the third study I compared bird abundance and species richness in upland versus riparian zones. Riparian zones were areas within $50 \mathrm{~m}$ of first- and second-order mountain streams. Overall, more birds were found on upland than on riparian sites; this was true at landscape, transect, and point scales. Abundance of Acadian flycatchers, Louisiana waterthrushes, wood thrushes, and hooded warblers was greater along streams, however.

Results of these studies suggest that this national forest is providing abundant habitat for Neotropical migrants and interior species. Of the four forest types, mixed mesophytic was generally associated with the greatest numbers of Neotropical migrants and interior species. Forest fragmentation effects were evident only at the local scale, and distinct only within $25 \mathrm{~m}$ of edges. With the exception of a few species, bird abundance and species richness in the riparian zones investigated were little different from those on upland sites. 
There are more things in heaven and earth, Horatio, than are dreamt of in your philosophy.

\section{-Hamlet}

In future studies, it would be interesting to vary the scale of landscape units to examine changes in species response to landscape structure according to the spatial resolution.

\section{-Villard et al., Conservation Biology, August 1999}

Let us run with determination, the race that lies before us.

-Hebrews 12:1 
Acknowledgments

Just as this dissertation presents a complex study at multiple scales, I must thank a substantial number of people and interrelationships who made it all possible.

I must first thank my wife Julie for her support throughout this process, for taking care of the kids so I could listen to birds at dawn every day, holding the fort during the many trips I made to Morgantown, and for giving me the time I needed to complete this work. She also made suggestions on the work at key points which strengthened it considerably, and may very well have saved the thesis from failure or stagnation. I thank our kids Patrick and Grace, also, for their patience and faith in me throughout this. At times Julie and the kids have had more faith in me than I have had in myself. As this work draws to a close, I look forward to more time with you.

Petra Wood graciously agreed to take me on as an older graduate student. Throughout this study she has maintained a solid, low-key flexibility that has seen us through a lot of challenges, financial, administrative, and scientific. I have enjoyed this collaboration and look forward to it continuing. There is so much material in this dissertation; surely we can make a cottage industry out of it.

Committee members Greg Elmes, Linda Gribko, Rose-Marie Muzika, and Charlie Yuill have also been gracious in their cooperation with me on this and other projects. I thank you all for what you have taught me over the past four years, and for your support of work on the Monongahela.

Dr. Robert Whitmore was an excellent teacher during my time at WVU. His ornithology field camp was truly one of the best learning experiences I have ever had. Before that week I was an amateur birder, after, a competent field ornithologist. I also am grateful for his class in statistics, which brought me back into the world of SAS and up to speed in statistical approaches.

Dr. Tim Warner helped me immensely in preparation of satellite images and fragmentation analyses. Thanks for having the faith in me, Tim, that I could manage this stuff.

I also thank my fellow students at WVU, among them Jeff Duguay, Katie Weakland, and Gary Williams. Jeff's thesis provided a model for some of the statistical approaches I used, particularly principal components analysis. Katie taught me how to do Mayfield analyses when I was completely stymied. Gary is carrying on the bird work on the Mon, for which I am very grateful.

During this study we built a set of working interrelationships with the Monongahela National Forest, the Forest Service research lab at Parsons, the West Virginia Division of National Resources, West Virginia University, the Coop Wildlife Unit at the University, and the national BBIRD monitoring program (Biological Resources Division of USGS). 
Thanks to all for the funding and interest in this study you have provided.

Donna Mitchell at WV DNR was an immense help throughout the study, by conducting the pilot study with me (it seems so long ago!), and helping to train the crews each field season. She was also an immense moral support to Julie and I during our time on the Mon.

The leadership team at the Monongahela National Forest was a critical part of this success, since they approved this study to meet forest planning needs. I thank them for allowing me the time to complete this study. Special thanks to Mike Herth, my supervisor at the time, for his support.

Finally, I thank all the field assistants who made this study possible. We don't honor or respect the contributions of field biologists in our profession anywhere as much as we should. In the 1996 field season, I was assisted by John Kennedy, Jane Rodrigue, Josh Lipton, Frank Williams, Charles Bower, Clint Epps, Nicky Frey, and Liz Carver. In 1997, Ron and Kathy Huffman, Joel Archibald, Adam Rollins, Chris Schowalter, Jane Rodrigue, Josh Lipton, Frank Williams, and Kieran O'Malley assisted. Ron also put in many hours entering data before and during the 1997 season. Frank, James Forester, and Brian Streets put in many hours GPSing plot boundaries and point count centers during the late summer and fall of 1997.

Each of you brought special talents to the job. Thanks for putting up with logistical struggles, delayed paychecks, and the relentless pace of the work. Thanks for following me on this landscape study to the ends of the earth, including the legendary North Fork Mountain. I will always be grateful.

Tom DeMeo

Sandy, Oregon

November 1999 


\section{TABLE OF CONTENTS}

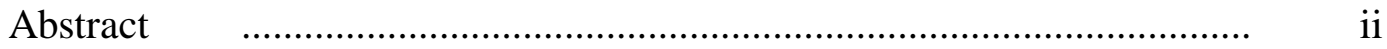

Acknowledgments ........................................................................... iv

List of Tables $\quad$............................................................................. viii

List of Figures $\quad$.......................................................................... xi

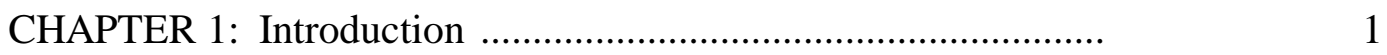

GLOSSARY $\quad$................................................................

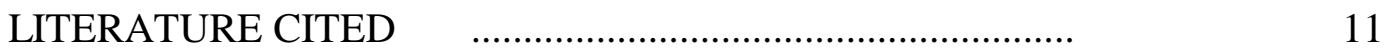

CHAPTER 2: Study Area and Methods

STUDY AREA

METHODS

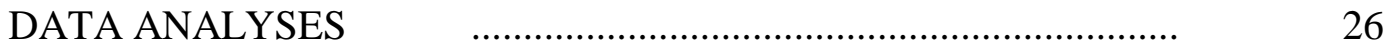

LITERATURE CITED $\quad$.............................................................. 31

CHAPTER 3: Relating Forest Songbird Abundance to Habitat at Multiple Scales on the Monongahela National Forest, West Virginia

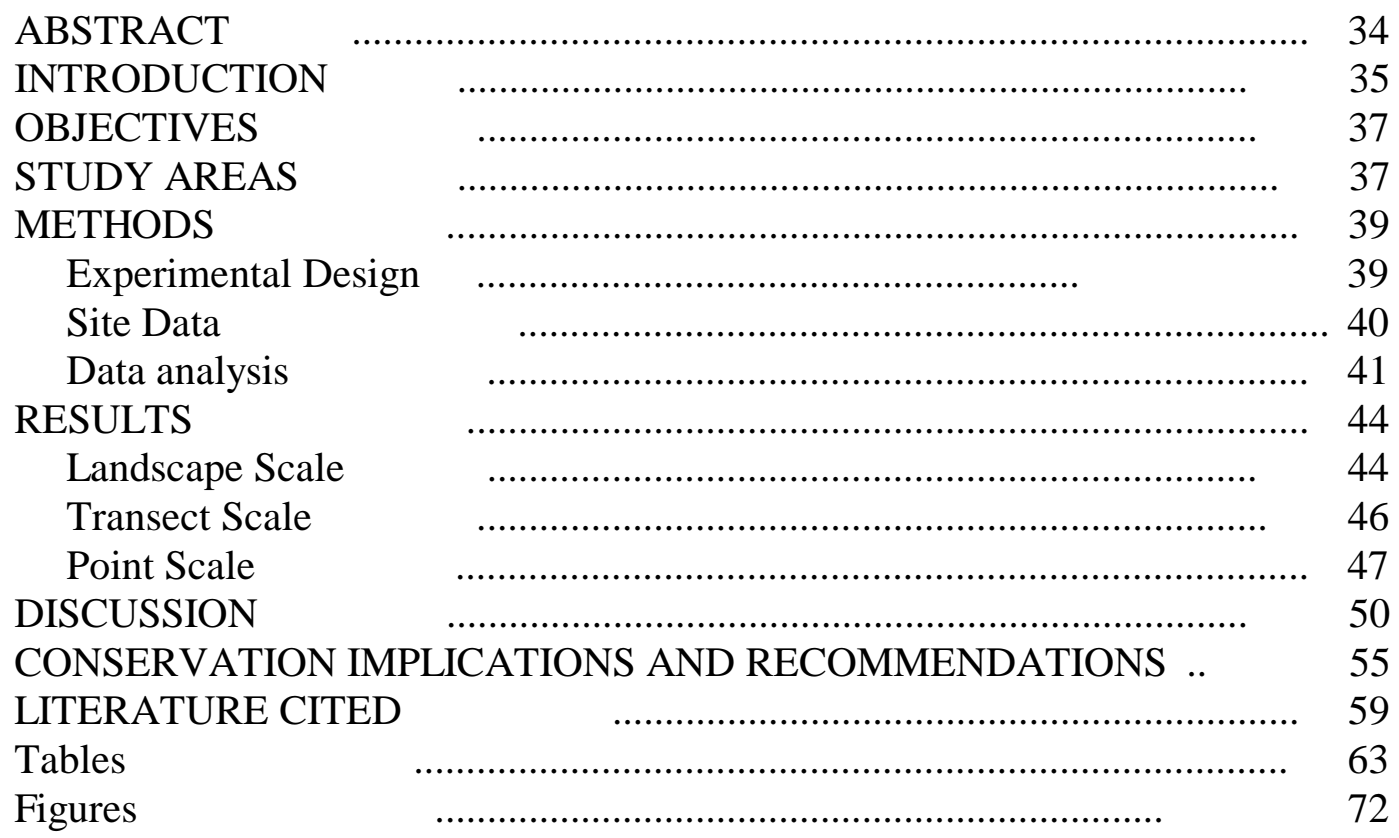


CHAPTER 4: Songbird Abundance and Viability At Multiple Scales Across a Range Of Fragmented Mixed Mesophytic Landscapes

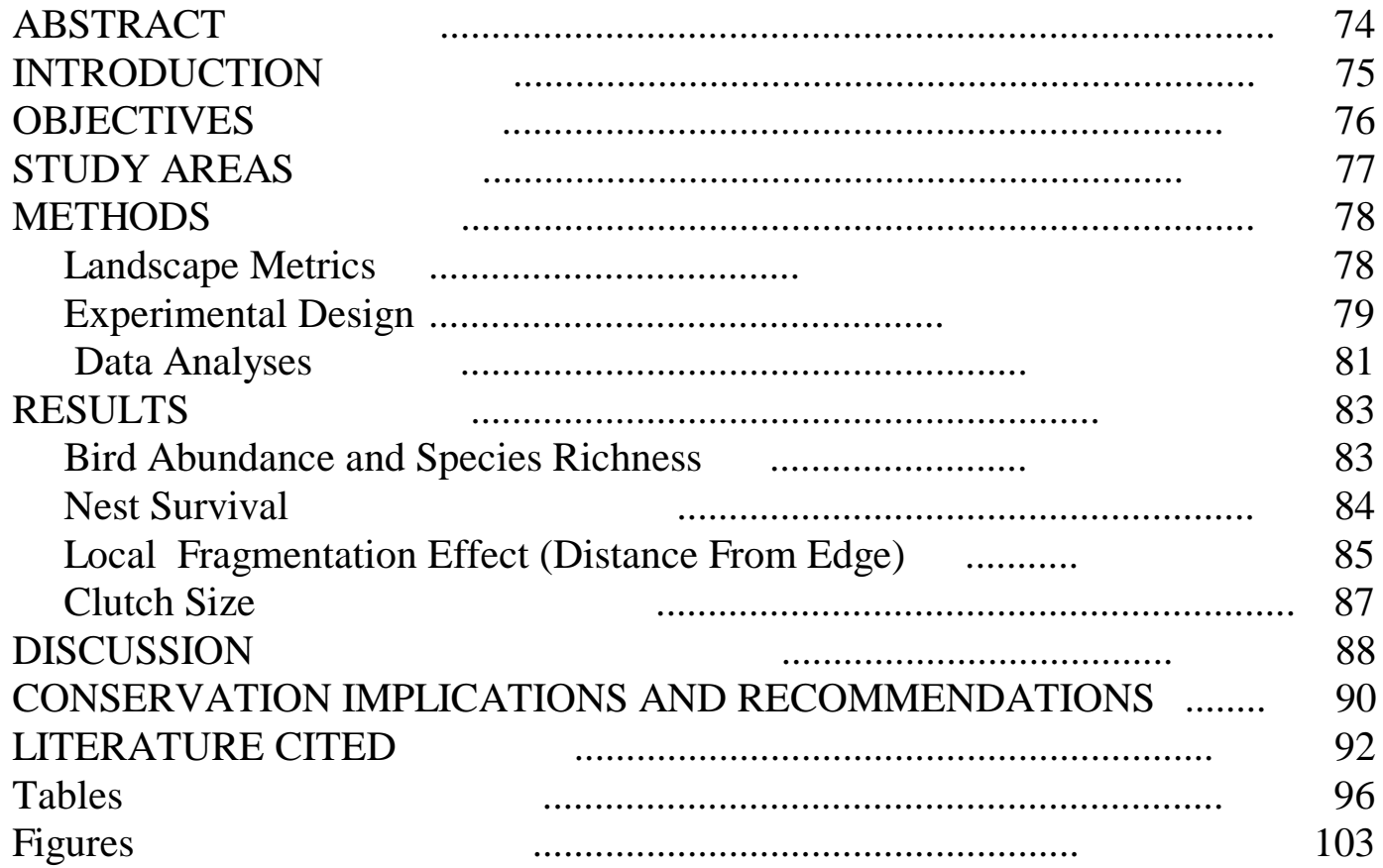

CHAPTER 5: Forest Songbird Abundance in Riparian versus Upland Habitat at Multiple Scales on the Monongahela National Forest, West Virginia

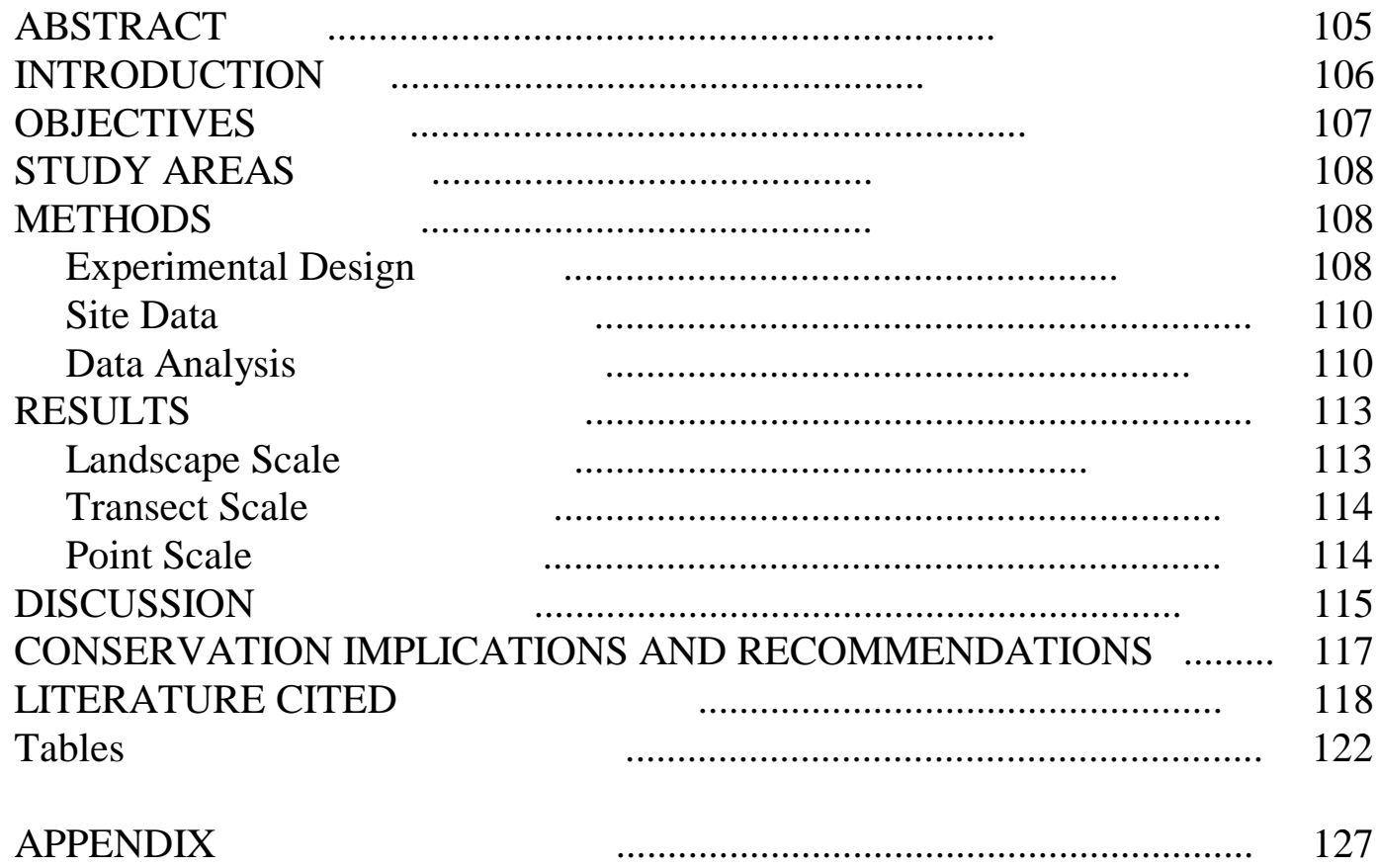




\section{LIST OF TABLES}

CHAPTER 3: Relating Forest Songbird Abundance to Habitat at Multiple Scales On the Monongahela National Forest, West Virginia

Tables

Table 3-1. Analysis of variance (ANOVA), entire point count set, with bird abundance and species richness as response variables in separate ANOVAs 63

Table 3-2. Bird abundance and species richness by bird group among the four major forest types of the Monongahela National Forest, 1996-1997

Table 3-3. Results of regression models to explain variation in bird abundance for all birds and selected guilds in each forest type, comparison of transect and point scales

Table 3-4.. Results of regression models to explain variation in bird abundance for the ten most abundant species in each forest type, comparison of transect and point scales.

CHAPTER 4: Songbird Abundance and Viability At Multiple Scales Across a Range Of Fragmented Mixed Mesophytic Landscapes

Table 4-1. Results of significance tests at multiple scales, Monongahela National Forest bird abundance, 1996-1997 96

Table 4-2. Results of significance tests at multiple scales, Monongahela National Forest bird species richness, 1996-1997

Table 4-3. Mayfield 27-day total survival estimates for the study areas, combined 19961997 data, Monongahela National Forest, WV

98

Table 4-4. The relationship of total nest survival to core area and edge density at the plot scale, 1996-1997 seasons, Monongahela National Forest

Table 4-5 Mean clutch size comparison of reference areas, combined 1996-1997 data on Monongahela National Forest study areas

Table 4-6. Nest survival by distance from edge (DTE) class, Monongahela National Forest study areas, 1996-1997 
Table 4-7. Comparison of nest survival on forest edges (0-25 $\mathrm{m}$ distance from edge) among edge types, Monongahela National Forest study areas, 1996-1997

CHAPTER 5: Forest Songbird Abundance in Riparian versus Upland Habitat at Multiple Scales on the Monongahela National Forest, West Virginia

Table 5-1. Comparison of upland and riparian mean bird abundance and species richness by bird group, Monongahela National Forest, 1996-1997

Table 5-2. Comparison of upland and riparian mean bird abundance and species richness by forest type, Monongahela National Forest, 1996-1997

123

Table 5-3. Significant distance to water effects, transect scale, for the top ten species in each forest type

Table 5-4. Significant distance to water effects, transect scale, for selected uncommon species abundance in each forest type

Table 5-5. Habitat variables significantly $(\mathrm{p}<0.05)$ associated with bird abundance, comparison of upland and riparian zones, by forest type 125

Table 5-6. Habitat variables differeing significantly between upland and riparian sites by forest type, Monongahela National Forest, 1996-1997 126 Appendix.

Table A-1. List of bird study areas, Monongahela National Forest, West Virginia, 19961997

Table A-2. Class variables used in the analyses of variance, point count data set, Monongahela National Forest bird study, 1996-1997

Table A-3. Ten most abundant species for each forest type

Table A-4. Analysis methods and variables analyzed at the three study scales on the .Monongahela National Forest, West Virginia, 1996-1997 … 130

Table A-5. Weights used for the edge types encountered on the Monongahela National Forest bird study, 1996-1997

Table A-6. Comparison of forest types, environmental and forest structural data, Monongahela National Forest bird study, 1996-1997 
Table A-8. Principal component factor loadings with eigenvalues greater than 1.00 by habitat variable, transect scale

Table A-9. Principal component factor loadings with eigenvalues greater than 1.00 by habitat variable, point scale

Table A-10. Significance of site variable effect on bird abundance for selected uncommon species

Table A-11. Comparison of mean abundance per sample point by bird group for each of the six mixed mesophytic study areas (landscapes), Monongahela National Forest, 19961997

Table A-12. Comparison of mean species richness per sample point by bird group for each of the six mixed mesophytic study areas (landscapes), Monongahela National Forest, 1996-1997

Table A-13. Comparison of least-squares mean abundance and species richness per transect by selected bird groups, Monongahela National Forest, West Virginia, 19961997

Table A-14 Results of significance tests for differences in clutch size, Monongahela National Forest nest search study areas (landscapes)/plots, 1996-1997 144

Table A-15 Results of significance tests for nest survival related to distance from edge, Monongahela National Forest, West Virginia, 1996-1997

Table A-16 Nest survival by distance from edge (DTE) class and edge type, Monongahela National Forest study areas, 1996-1997

Table A-17. Results of significance tests at multiple scales, effect of site habitat variables on nest survival, Monongahela National Forest study areas, 1996-1997

Table A-18. Site habitat effects on clutch size by bird group $\quad$....... $\quad 148$ 


\section{LIST OF FIGURES}

Figure 3-1. False-color infrared LANDSAT image of the Monongahela National Forest, West Virginia

Figure 3-2. Study design, bird point counts at multiple scales, Monongahela N.F. 61

Figure 4-1. Study design, bird point counts and nest search plots at multiple scales, Monongahela N.F 94

Figure 4-2. The relationship of interior-edge species nest survival to plot core area 103 


\section{Chapter 1. Introduction}

In recent years, declines of several songbird groups in the eastern United States have generated much concern (Askins et al. 1990, Peterjohn and Sauer 1994, Hagan and Johnston 1992). Recent research has focused on both wintering and summer breeding grounds in the search for factors limiting populations (Sherry and Holmes 1992a, Rappole and McDonald 1994). While the debate on the relative importance of limiting factors on summer versus winter grounds continues, summer breeding habitat is probably important in maintaining songbird populations (Morton 1992, Sherry and Holmes 1992b).

Another emerging theme in songbird work is that risks to bird populations vary throughout the eastern United States. Beyond an initial general realization of songbird declines, researchers have begun to focus on the relative values of different subregions, and the risks birds face within them. For example, while brownheaded cowbirds (Molothrus ater) are abundant and pervasive in Midwestern landscapes (Robinson 1992, Donovan et al. 1995), there is no evidence they have been increasing in the eastern U.S. over the past 25 years (James and McCulloch 1995). While Neotropical migratory birds (NTMBs) appear to be declining in eastern Maryland (Robbins et al. 1989, Dawson et al. 1993), as a group they do not appear to be declining in New England (Smith et al. 1993).

Within the eastern United States, forests of the Central Appalachians, notably those of the Allegheny Plateau, are thought to provide one of the most important summer breeding habitat for 
songbirds. In an analysis of the relative value of physiographic provinces for songbird populations, Rosenberg and Wells (1995) ranked the Allegheny Plateau among the top five provinces for 28 of 34 species of interest. Further, they ranked West Virginia and adjacent highland areas of Maryland as a "major area of high importance."

In planning to maintain viability of these forest songbird populations, multiple scales must be considered (Harris 1984, Noss and Cooperrider 1994, Freemark et al. 1995). Management of species at the local (e.g., forest stand) scale is no longer considered adequate (Kessler et al. 1992, Freemark et al 1995), because ecosystem processes and habitats are linked (Harris 1984, Soule and Simberloff 1986, Simberloff 1988, Noss 1992). What happens in areas adjacent to the habitat of concern matters (Thomas et al. 1990). An understanding of how landscape pieces fit together is essential to any management plan for the viability of species (Noss1983, Noss and Cooperrider 1994, Trani and Giles 1999). Spatial patterns can be used to explain species distributions (Burgess and Sharpe 1981, Freemark et al. 1995), often identifying underlying reasons for species occurrences.

Freemark et al. (1995) provide an excellent outline of how these concepts relate to migratory songbirds. Habitat selection by neotropical migrants involves response to habitat pattern at hierarchical levels, including the territory, patch, and landscape. All habitats are not of equal quality, since birds tend to select some over others because of better opportunities for feeding, successful reproduction, and dispersal.

Hierarchy theory (Allen and Starr 1982) provides the framework for practical work with multiple scales. This theory describes systems as nested within each other in a logical, ordered 
fashion. To describe diversity at multiple scales, Whittaker (1960) coined the terms alpha, beta, and gamma diversity. Alpha represents diversity at the local or site scale. An example would be the number of plant species in a 0.5 ha woodlot. Beta diversity represents the change across the landscape. A highly dissected forested mountain region (such as the Central Appalachians) would have greater beta diversity than a flat region with little physiographic relief. Finally, gamma diversity is represented at broad landscape or regional scales, where the range of all habitats can be fully expressed.

Consideration of multiple scales is also necessary so that sets of local populations linked by dispersal (metapopulations) (Merriam 1988, Pulliam 1988) can interact. These concepts have grown out of MacArthur and Wilson's (1967) early work on island biogeography, and have in recent years led to the source/sink theory. Source areas are those that produce excess individuals over time. Sink areas are those with individuals that will go extinct unless they receive immigration from source areas (Hanski and Gilpin 1997). Using these concepts, we can hypothesize that the Central Appalachians would provide a source area for the sink areas of the Midwest and the Atlantic coastal plain.

While large intact forest areas, such as those of the Central Appalachians, are generally thought to have great value as source areas, documentation of this with field studies remains poor. Donovan et al. (1995) provide one of the few studies comparing fragmented and contiguous forest tracts. Breeding bird survey data, while valuable, has limited inference on intact areas, since it is collected along roads (Peterjohn and Sauer 1994). 
Consideration of landscapes has led to concerns over fragmentation of landscapes (Faaborg et al. 1993). Fragmentation can be defined as the reduction and isolation of forest habitat through logging, roadbuilding, agriculture, development, and other human activities (Morrison et al. 1992). Faaborg et al. (1995) outlined effects of forest fragmentation on bird populations: 1) habitat loss, 2) increase in edge habitat and edge effects, and 3) isolation of remaining forest fragments.

When forest is fragmented, some area of forest is of course lost, at least temporarily. Additionally, however, opening of the forest through logging, roadbulding, etc. generates abrupt edges. Edges are transitional areas from one ecosystem to the next (Gosz 1991); some birds are favored by edges, and others are adversely affected. Adverse effects of edges include altering of microclimate, creating a more favorable environment for predators and nest parasites, and facilitating predator movement (particularly with road corridors) (Faaborg et al. 1995).

Potential effects of multiple scales and fragmentation are best illustrated with an example: dispersion of clearcuts throughout a forest can increase local diversity, but generate greater risk at the landscape scale. Fragmenting an area with logging or road building can increase the number of species (one measure of diversity), as edge-favored species move into an area. Given enough additional fragmentation, however, species requiring undisturbed interior areas could be adversely affected to the point of local extinction (Franklin and Forman 1987, Noss and Cooperrider 1994).

Forest fragmentation is therefore often listed as a major cause of NTMB declines (Temple and Cary 1988, Wilcove 1985, Morrison et al. 1992, Haskell 1995). Species adversely affected 
by edge are often called interior-dependent (Whitcomb et al. 1981, Freemark and Collins 1992). Species found in large forest tracts but not small ones are known as area-sensitive. While the two terms are often used interchangeably, this is incorrect (Villard 1998). (Birds using interior forest for nest sites, but feeding along edges are known as interior-edge species.) The low abundance of certain species in small fragments is well-documented (Robbins et al. 1989, Blake 1991), but evidence for edge-avoidance is much more tenuous (Villard 1998, King et al. 1997).

Initial work on fragmentation effects on birds in the eastern U.S. indicated adverse effects in highly-fragmented areas (Temple and Cary 1988, Robbins et al. 1989, Robinson 1992). Research attention has now turned to more intact areas (Rudnicky and Hunter 1993, Askins 1994, Hagan et al. 1996, Trine 1998). Intact areas are important because they can serve as source areas, providing surplus birds to maintain populations in areas otherwise facing extinction (sinks) (Pulliam 1988, Hanski and Gilpin 1997). Whereas edge is easily created through human activities, intact areas can only develop through natural processes over time.

Within large, relatively intact forests, understanding the threshold of critical fragmentation effect would be of great value to conservation planning. Donovan et al. (1995) suggested $40 \%$ forest core area as a threshold where source areas became sinks in landscapes with productive source areas. Increases in edge habitat and reduced forest core area tend to favor brown-headed cowbird abundance and brood parasitism (Brittingham and Temple 1983, Robinson et al. 1995). In the highly-fragmented Midwestern landscapes studied by Donovan et al. (1995), cowbirds were so pervasive they could invade virtually any forest area with less than $40 \%$ core area. While the Central Appalachians are thought to be a strong source area, quantification of this 
strength, and how it varies with forest type, remains a pressing need for population viability assessment.

Riparian habitats (streamside zones) are often thought to provide special values in landscapes. Freemark et al. (1995) considered 58 bird species as area-sensitive; $45 \%$ of these were associated with riparian habitats. Adjacent upland areas affect streamside zones (Stamp 1978) and appears related to degree of contrast. In agricultural landscapes, riparian strips provide "refuge habitat" for birds not otherwise available in the landscape (Hehnke and Stone 1978). In a Western forested landscape, McGarigal and McComb (1992) found more birds in adjacent upslope habitats than along streams. Murray and Stauffer (1995) working in dry oak forests of Virginia, found a lack of riparian effect on bird abundance, with the exception of Louisiana waterthrushes (Seiurus motacilla) and Acadian flycatchers (Empidonax virescens), two species well-known for their riparian affinity.

Because the Monongahela National Forest (MNF) is facing revision of its forest plan within the next few years, a timely opportunity exists to assess the strength of the MNF landscape as a source area of forest songbirds. The MNF contains large, relatively intact forested areas with potential to provide forest songbird habitat well into the future. Data are needed on the relative value of the four major forest zones present on the MNF for NTMB habitat, since this will play a central role in design of reserve areas. Information on the variation of habitats, and identification of bird "hotspots" within these forest zones, is also important. To more accurately describe impacts of logging and road-building on forest songbird habitat, a better understanding of fragmentation effects is needed. In this way, the optimal mix of open and 
forested habitats can be more clearly understood. Finally, identifying the full contribution of forested riparian zones to broader ecosystem diversity remains a pressing concern.

\section{Objectives}

I therefore identified specific study objectives as follows:

1) Compare the relative value of habitat at multiple scales. A broad scope of inference is called for, since information on a limited area could lead to erroneous conclusions if extrapolated across the landscape (McGarigal and McComb 1995). Further, while the Allegheny Mountains are thought to be an important source of forest songbirds for the eastern U.S. (Rosenberg and Wells 1995), quantification of this source is lacking.

At the landscape scale, one cannot assume the four major forest zones (dry oaks (Quercus spp.), mixed mesophytic, northern hardwoods, and red spruce (Picea rubens)) provide the same songbird habitat, since these forest types vary in elevation and site productivity (Hurst 1994, McCay et al. 1997, DeMeo 1998). Assessing variation within landscapes is equally important, in order to identify local "hotspots" of greater habitat value. Finally, at the local scale, environmental variables such as aspect, site productivity, and forest canopy diversity may be influencing bird occurrence.

2) Identify forest fragmentation effects on bird abundance and viability in relatively intact landscapes. Research is only beginning to determine fragmentation effects in intact landscapes, with evidence they may be quite different from those in highly-fragmented areas (Fahrig 1997, Hagan et al. 1996). In particular, whether forest fragmentation effects are only local (along 
edges), or can be related to the entire landscape (by finding changes in bird abundance/viability with total forest core area) will obviously affect forest planning.

3) Determine the unique values of riparian zones. Because riparian zones are thought to have special value in the structure, function, and composition of landscapes (Gates and Giffen 1991, Darveau et al. 1995, Murray and Stauffer 1995), a comparison of riparian versus upland areas is called for.

Accordingly, I initiated a study of the MNF to assess songbird-habitat relationships forestwide at multiple scales, and to assess forest fragmentation effects in the mixed mesophytic forest zone, the forest type most often impacted by management. I also compared bird abundance along mountain streams versus upland areas. A limited pilot study was conducted in 1995 to determine logistical constraints, and in 1996 and 1997 the study was expanded to include the data presented in this dissertation.

In Chapter 2 I describe the study area and methods used to address these research questions. Chapter 3 is a presentation of abundance-habitat relationships at multiple scales (objective 1) by the use of point counts in four forest types across the MNF. In Chapter 4, I report on forest fragmentation effects on bird abundance and viability across a range of fragmented mixed mesophytic landscapes (objective 2). Finally, in Chapter 5 I compare bird abundance along forested mountain streams with forested upland sites (objective 3). 


\section{Glossary}

Abundance. In this document, the total number of birds counted at a point.

Alpha diversity. Local, or site-level variety of plants or animals.

Area-sensitive. Species that cannot successfully use small habitat patches for their reproduction and survival; they require large habitat patches.

Beta diversity. Change in habitats across a landscape. A highly-fragmented landscape has greater beta diversity than an intact one.

Core area. Forest area minus an edge-effect width. The width depends on the parameter of interest. Often expressed as a percentage of the landscape.

Depauperate. Lacking forest floor or shrub vegetation layers.

Diversity. The variety of life and its processes.

Edge species. In the context of this dissertation, birds that prefer the zone of contrasting forest and open (e.g., roads, clearcuts, etc.) habitats for reproduction and survival.

Gamma diversity. Overall landscape or regional diversity.

Hierarchy theory. First presented by Allen and Starr (1982), this is an organizing principle for nesting landscapes within each other based on different processes at different levels (scales).

Interior species. Birds requiring conditions within large habitat patches, away from edges.

Interior-edge species. Birds that use interior conditions for reproduction but use edge areas for feeding or other functions. 
Island biogeography theory. Presented by MacArthur and Wilson (1967), this examines the number of species and individuals on islands, as well as effects of dispersal,colonization and extinction. Size and proximity of the islands are important criteria. These fundamental concepts have served as the philosophical underpinnings for later work on population viability and fragmentation of forest into habitat "islands."

Fragmentation. The process of isolating habitat patches through logging, roadbuilding, agriculture, and other development. Its main effects are: 1) loss of habitat, 2) generation of edge effects, and 3) isolation of populations (Morrison et al. 1992).

Landscape. An area of the earth's surface broad enough to encompass the range of beta diversity typical of that area. Landscapes can be nested within other landscapes at broader scales.

Metapopulation. A group of subpopulations of a species, linked through dispersal.

Multiple scales. Nested areas of consideration on the landscape. Ecosystem structure, function, and composition usually differ among the scales. Derived from Allen and Starr's (1982) hierarchy theory.

Neotropical migratory bird (NTMB). Birds spending the winter in the tropics and migrating north in the spring to use portions of the United States and Canada for nesting, reproduction, and fledging of young.

Physiographic relief. The variety of landforms across a landscape, with particular reference to changes in elevation.

Population viability. Ability of a group of individuals to maintain their numbers over time 
through successful reproduction and survival. These groups, or subpopulations of a species, when linked through dispersal, form a metapopulation.

Riparian zone. In the context of this dissertation, the area on either side of a first- or secondorder mountain stream hypothesized to be of special value to birds.

Sink. Area where a population cannot maintain itself without immigration from a source.

Source. Area producing a surplus of individuals; these can serve to populate sinks.

Species richness. The total number of species.

\section{Literature Cited}

Allen, T.F.H., and T.B. Starr. 1982. Hierarchy: perspectives for ecological complexity. Chicago: Univ. of Chicago Press, 310 pp.

Askins, R.A. 1994. Open corridors in a heavily forested landscape: Impact on shrubland and forest-interior birds. Wildlife Soc. Bull. 22:339-347.

Askins, R.A., J.F. Lynch, and R. Greenberg. 1990. Population declines in migratory birds in eastern North America. pp. 1- 57 in Power, D.M. (ed.) Current ornithology: volume 7 New York: Plenum Press.

Blake, J.G. 1991. Nested subsets and the distribution of birds of isolated wodlots. Conserv. Biol. 5:58-66.

Brittingham, M. and S. Temple. 1983. Have cowbirds caused forest songbirds to decline? BioScience 33:31-35.

Burgess, R.L., and D.M. Sharpe, eds. 1981. Forest island dynamics in man-dominated landscapes. New York: Springer-Verlag.

Darveau, M., P. Beauchesne, L. Belanger, J. Huot, and P. Larue. 1995. Riparian forest strips as habitat for breeding birds in boreal forest. J. Wildl. Manage. 59(1):67-78. 
Dawson, D.K., L.J. Darr, and C.S. Robbins. 1993. Predicting the distribution of breeding forest birds in a fragmented landscape. Trans. 58th N.A. Wildl. \& Natur. Resour. Conf., pp. 35-43.

DeMeo, T.E. 1998. Terrestrial ecological classification of the Monongahela National Forest, West Virginia. Elkins, WV:

USDA For. Serv. Unpub. Report on file.

Donovan, T.M., R.H. Lamberson, A. Kimber, F.R. Thompson III, and J. Faaborg. 1995.

Modeling the effects of habitat fragmentation on source and sink demography of neotropical migrant birds. Conserv. Biol. 9(6):1396-1407.

Faaborg, J., M. Brittingham, T. Donovan, and J.Blake. 1993. Habitat fragmentation in the temperate zone: a perspective for managers. pp. 331-338 in D.M. Finch and P.W. Stangel, eds. Status and management of neotropical migratory birds.

Fort Collins, CO: USDA For. Serv. Gen. Tech. Rep. RM-229, Rocky Mt. Forest and Range Exp. Sta.

Faaborg, J., M.C. Brittingham, T.M. Donovan, and J.G. Blake.1995. Habitat fragmentation in the temperate zone. pp. 357-380 in T.E. Martin and D.M. Finch, eds. Ecology and management of migratory birds: a synthesis and review of critical issues. Oxford University Press, Oxford, England.

Fahrig, L. 1997. Relative effects of habitat loss and fragmentation on population extinction. J. Wildl. Manage. 61(3):603-610.

Frankin, J.F., and R.T.T.Forman. 1987. Creating landscape patterns by forest cutting: Ecological consequences and principles. Landsc. Ecol. 1:5-18.

Freemark, K., and B. Collins. 1992. Landscape ecology of birds breeding in temperate forest fragments. pp. 443-454 in J.M. Hagan III and D.W. Johnston, eds. Ecology and conservation of neotropical migrant landbirds. Washington, DC: Smithsonian Institution Press.

Freemark, K., J.B. Dunning, S.J. Hejl, and J.R. Probst. 1995. A landscape ecology perspective for research, conservation, and management. pp. 381-427 in T.E. Martin and D.M. Finch, eds. Ecology and management of Neotropical migratory birds. New York: Oxford Univ. Press.

Gates, J.E., and N.R. Giffen. 1991. Neotropical migrant birds and edge effects at a foreststream ecotone. Wilson Bull.103(2):204-217. 
Gosz, J.R. 1991. Fundamental ecological characteristics of landscape boundaries. pp. 8-30 in Holland, M.M., P.G. Risser, and R.J. Naiman, eds. Ecotones: The role of landscape boundaries in the management and restoration of changing environments. New York: Chapman and Hall.

Hagan, J.W., III and D.W. Johnston (eds.) 1992. Ecology and conservation of Neotropical migrant landbirds. Smithsonian Institution Press, Washington, DC.

Hagan, J.M., W.M. vander Haefen, and P.S. McKinley. 1996. The early development of forest fragmentation effects on birds. Conserv. Biol 10(1):188-202.

Hanski, I.A., and M.E. Gilpin, eds. 1997. Metapopulation biology: Ecology, genetics, and evolution. New York: Academic Press, 512 pp.

Harris,L.D. 1984. The fragmented forest: Island biogeography theory and the preservation of biotic diversity. Chicago: Univ. of Chicago Press, 211 pp.

Haskell, D.G. 1995. A reevaluation of the effects of forest fragmentation on rates of bird-nest predation. Conserv. Biol. 9(5):1316-1318.

Hehnke, M., and C.P. Stone. 1978. Value of riparian vegetation to avian populations along the Sacramento River system. Pp. 228-235 in Strategies for protection and management of floodplain wetlands and other riparian ecosystems (R.R. Johnson and J.F. McCormick, tech. Coords). USDA For. Serv. Gen. Tech. Rep. WO-12.

Hurst, D. 1994. Ecological gradient analysis of the Monongahela National Forest. University Park, PA: Penn State Univ. School of For. Res. M.S. Thesis.

James, F.C., and C.E. McCulloch. 1995. The strength of inferences about causes of trends in populations. pp. 40-54 in T.E. Martin and D.M. Finch, eds. Ecology and management of Neotropical migratory birds. New York: Oxford Univ. Press.

Kessler, W.B., H. Salwasser, C.W. Cartwright, Jr., and J.A. Caplan. 1992. New perspectives for sustainable natural resources management. Ecol. Applic. 2:221-225.

King, D.I., C.R. Griffen, and R.M. DeGraaf. 1997. Effect of clearcut borders on distribution and abundance of forest birds in northern New Hampshire. Wilson Bull. 109(2):239-245.

MacArthur, R.H., and E.O. Wilson. 1967. The theory of island biogeography. Princeton, NJ: Princeton Univ. Press, 203 pp. 
McCay, D.H., M.D.Abrams, and T.E. DeMeo. 1997. Gradient analysis of secondary forests of eastern West Virginia. J. Torrey Bot. Soc. 124(2):160-173.

McGarigal, K., and W.C. McComb. 1992. Streamside versus upslope breeding bird communities in the central Oregon Coast Range. J. Wildl. Manag. 56:10-23.

McGarigal, K., and W.C. McComb. 1995. Relationships between landscape structure and breeding birds in the Oregon Coast Range. Ecol. Mongr. 65(3):235-260.

Merriam, G. 1988. Landscape dynamics in farmland. Trends in ecology and evolution 3:16-20.

Morrison, M.L., B.G. Marcot, and R.W. Mannan. 1992. Wildlife-habitat relationships: Concepts and applications. Madison, WI: Univ. of Wisc. Press, 343 pp.

Morton, E.S. 1992. What do we know about the future of migrant landbirds? pp. 579-589 in J.M. Hagan III and D.W. Johnston, eds. Ecology and conservation of neotropical migrant landbirds. Washington, DC: Smithsonian Institution Press.

Murray, N.L., and D.F. Stauffer. 1995. Nongame bird use of habitat in Central Appalachian riparian forests. J. Wildl. Manage. 59(1):78-88.

Noss, R.F. 1983. A regional landscape approach to maintain diversity. BioScience 33:700-706.

Noss, R.F. 1992. Issues of scale in conservation biology. pp. 239-250 in P.L. Fiedler and S.K. Jains, eds. Conservation biology: The theory and practice of nature conservation, preservation, and management. New York: Chapman and Hall.

Noss, R.F., and A.Y.Cooperrider. 1994. Saving nature's legacy. Washington, DC: Island Press, $416 \mathrm{pp}$.

Peterjohn, B.G., and J.R. Sauer. 1994. Population trends of woodland birds from the North American breeding bird survey. Wildl. Soc. Bull. 22:155-164.

Pulliam, H.R. 1988. Sources, sinks and population regulation. American naturalist 137:550566.

Rappole, J.H., and M.V. McDonald. 1994. Cause and effect in population declines of migratory birds. Auk 111(3):652-660.

Robbins, C.S., D.K. Dawson, and B. Dowell. 1989. Habitat area requirements of breeding forest birds of the Middle Atlantic states. Wildl. Monogr. 103, 34 pp. 
Robinson, S.K. 1992. Population dynamics of breeding neotropical migrants in a fragmented Illinois landscape. in J.M. Hagan III and D.W. Johnston, eds. Ecology and conservation of neotropical migrant landbirds. Washington, DC: Smithsonian Institution Press.

Robinson, S., S. Rothstein, M. Brittingham, L. Petit, and J. Grybowski. 1995. Ecology and behavior of cowbirds and their impact on host populations. In T. martin and D. Finch, eds., Ecology and management of Neotropical Birds: A synthesis and review of critical issues. Oxford University Press, New York.

Rosenberg, K.V., and J.V. Wells. 1995. Importance of geographic areas to neotropical migrant birds in the Northeast. Hadley, MA: USDI Fish and Wildl. Serv. Report, 120 pp.

Rudnicky, T.C., and M.L. Hunter, Jr. 1993. Avian nest predation in clearcuts, forests, and edges in a forest-dominated landscape. J. Wildl. Manage. 57(2):358-364.

Sherry, T.W., and R.T. Holmes. 1992a. Are populations of neotropical birds limited in summer or winter? pp. 47-87 in Status and management of neotropical migratory birds. Fort Collins, CO: USDA For. Serv. Gen. Tech. Rep. RM-229.

Sherry, T.W., and R.T. Holmes. 1992b. Population fluctuations in a long-distance Neotropical migrant: Demographic evidence for the importance of breeding season events in the American Redstart. pp. 431-442 in J.M. Hagan III and D.W. Johnston, eds. Ecology and conservation of neotropical migrant landbirds. Washington, DC: Smithsonian Institution Press.

Simberloff, D. 1988. The contribution of population and community biology to conservation science. Ann. Rev. of Ecol. and Systematics 19:473-511.

Smith, C.R., D.M. Pence, and R.J. O'Connor. 1993. Status of Neotropical birds in the Northeast: A preliminary assessment. in Status and management of Neotropical migratory birds. Fort Collins, CO: USDA For. Serv. Gen. Tech. Rep. RM-229, pp. 172-184.

Soule, M.E., and D. Simberloff. 1986. What do genetics and ecology tell us about the design of nature reserves? Biol. Conserv. 35:19-40.

Stamp, N.E. 1978. Breeding birds of riparian woodland in south-central Arizona. Condor 80:64-71.

Temple, S.A., and J.R. Cary. 1988. Modeling dynamics of habitat-interior bird populations in fragmented landscapes. Conserv. Biol. 2(4):340-347. 
Thomas, J.W., E.D. Forsman, J.B. Lint, E.C. Meslow, B.R. Noon, And J. Verner. 1990. A conservation strategy for the northern spotted owl. Portland, OR: USDA For. Serv., USDI Bureau of Land Man., USDI Fish and Wildl. Service, and USDI Nat. Park Serv.

Trani, M.K., and R.H. Giles, Jr. 1999. An analysis of deforestation: Metrics used to describe pattern change. For. Ecol. and Manage. 114:459-470.

Trine, C.L. 1998. Wood thrush population sinks and implications for the scale of regional conservation strategies. Conserv. Biol. 12(3):576-585.

Villard, M.A. 1998. On forest-interior species, edge avoidance, area sensitivity, and dogmas in avian conservation. Auk 115(3):801-805.

Whitcomb, R.F., C.S. Robbins, J.F. Lynch, B.L. Whitcomb, M.K. Klimkiewicz, and D. Bystrak. 1981. Effects of forest fragmentation on avifauna of the Eastern deciduous forest. pp. 125-205 in Burgess, R.L., and D.M. Sharpe, eds. Forest island dynamics in mandominated landscapes. New York: Springer Verlag.

Wilcove, D.S. 1985. Nest predation in forest tracts and the decline of migratory songbirds. Ecology 66:1211-1214. 


\section{Chapter 2. Study Area and Methods}

\section{Study Area}

This study was conducted on the Monongahela National Forest (MNF), encompassing 367,611 hectares in eastern West Virginia (Fig. 3-1). The MNF falls within two broad physiographic provinces: the Ridge and Valley, encompassing the eastern $1 / 4$ of the MNF, and the Allegheny Mountains, forming the remainder (McNab and Avers 1994). The Ridge and Valley portion falls within the rain shadow of the Allegheny Mountains, and hence receives about half $(75 \mathrm{~cm} /$ year) the rainfall of the latter $(115-150 \mathrm{~cm} /$ year $) . \quad$ The MNF is a key source of biodiversity in the region, as it covers an elevation range of 275-1480 m, a latitudinal range of approximately $200 \mathrm{~km}$, and four major forest zones (dry oaks, mixed mesophytic, northern hardwoods, and red spruce) (Kuchler 1964).

Mixed mesophytic forests are characterized by sugar maple (Acer saccharum Marsh.) and red oak (Quercus rubra L.), typically at elevations below $900 \mathrm{~m}$ in the Allegheny Mountains (Core 1966, Burns and Honkala 1990, McNab and Avers 1994). Soils are typically welldrained and derived from sandstone or shale. The most productive sites are in coves (hollows) where soil colluvium and nutrients collect. On these sites, basswood (Tilia americana L.), white ash (Fraxinus americana L.), and tulip poplar (Liriodendron tulipifera L.) are common associates of sugar maple and red oak. Also noteworthy are productive sites on soils of the Cateache series, derived from a nutrient-rich red shale. On drier aspects, blueberry (Vaccinium spp. L.) or mountain laurel (Kalmia latifolia L.) may characterize the understory. On ridges, chestnut oak (Quercus montana Willd.) and red maple (Acer rubrum L.) are associated with red oak, and sugar maple may be absent. 
On the MNF, northern hardwoods generally occur at higher elevations (900 to $1150 \mathrm{~m}$ ) than mixed mesophytic forests (Stephenson 1993). Soils, while also derived from sandstone and shale, tend to be less productive. Productivity is restricted by higher elevation, leading to shorter growing seasons, and often also by shallow and less nutrient-rich soils. Vegetation is characterized by an American beech (Fagus grandifolia Ehrh.) overstory. Sugar maple and black cherry (Prunus serotina Ehrh.) occur on more nutrient-rich sites, with southern aspects favoring cherry and northern aspects favoring sugar maple. Some productive riparian zones in coves will feature basswood in association with beech, but more often streams are passing through nutrient-poor bedrock. These areas are characterized by yellow birch (Betula alleghaniensis Britt.) and eastern hemlock (Tsuga canadensis L.); rhododendron (Rhododendron maxima L.) also is often present.

Red spruce (Picea rubens Sarg.) sites occur at the highest elevations of the MNF, from 1150 to $1450 \mathrm{~m}$. This environment is characterized by cold temperatures that restrict productivity, and by poorly-developed soils (White and Cogbill 1992). Many of these sites were severely burned following the 1880-1920 logging era, with serious soil damage that has resulted in shrublands rather than forest. For this study, I selected only study areas characterized by a developed forest overstory. Most study areas include areas of mixed beech and spruce as well as pure spruce.

In contrast to the other three forest types, dry oaks are found primarily in the eastern portion of the MNF. This Ridge and Valley area features a notably drier ecosystem than that of the other three forest types in the Allegheny Mountains to the west (annual precipitation about $75 \mathrm{~cm}$, compared with $115-150 \mathrm{~cm}$ in the Alleghenies). Productivity is limited by low rainfall, often exacerbated by nutrient-poor and droughty soils. Vegetation is characterized 
by white (Quercus alba L.) and chestnut oak, with scarlet (Quercus coccinea Muench.) and black oaks (Quercus velutina Lam.) on drier sites, and the "dry pines" (table mountain pine (Pinus pungens Lamb.), pitch pine (P. rigida Mill.), and Virginia pine (P.virginiana Mill.)) on the poorest sites. Dry oaks also occur in the southeastern portion of the MNF. Sites here are also characterized by dry oaks, but somewhat moister sites with white pine (Pinus strobus L.) and white or chestnut oak are common. Before it was decimated in the early 1900 s by a blight (Endothia parasitica), American chestnut (Castanea dentata Marsh.) was common in this area.

\section{Methods}

\section{Selection of study landscapes}

In the study of bird abundance at multiple scales (Chapters 3 and 5), I investigate birdhabitat relationships in relatively intact areas typical of the MNF. Accordingly, in 1996 three intact study areas, each $25 \mathrm{~km}^{2}$ in area, were randomly selected for each of the four major forest types on the MNF (mixed mesophytic, northern hardwoods, dry oaks, and red spruce) (Appendix Table A-1; see also Fig. 3-1).

Study areas were considered intact if they contained at least 60 percent core area. Core area was considered forest area minus a 100-m edge width (Temple and Cary 1988). Core areas of each study area were calculated with FRAGSTATS (McGarigal and Marks 1995), a widely-used fragmentation analysis package. LANDSAT images from July 1992 were used as the data source; images were converted from false-color composites to open-versusforested images using an unsupervised classification technique (Idrisi 1995). If a study area did not meet the minimum core area, it was eliminated and another study area was randomly selected. The final 12 selected study areas ranged from 61 to 88 percent core area. 
In a study of bird abundance and viability across a range of fragmented mixed mesophytic landscapes (Chapter 4), study areas in the range of 40-100 percent core area were selected. Donovan et al. (1995b), working in the Midwest, suggested that 40 percent core area might be a threshold where source areas would begin to function as sinks. In this portion of the study, I focused on one forest type (mixed mesophytic) and selected six study areas ranging from 42 to 85 percent core area. Note that three of these (with core areas greater than 60 percent) were the same as those used in the landscape study; the other three (with core areas less than 60 percent) were added for the fragmentation study. For all study areas, I also calculated edge density (length of edge in meters per 100 hectares), another useful measure of fragmentation.

\section{Overview of Field Methods}

In the landscape and riparian studies (Chapters 3 and 5), I used point counts to measure bird abundance. Point counts are a popular method because the individual count is not timeconsuming, and because little equipment is necessary. Point counts are widely used and methods are becoming standardized (Ralph et al. 1993).

One drawback of point count methods, however, is that bird abundance cannot be used to infer viability (the ability of a population to maintain itself over time). Because birds are present in an area does not necessarily mean they use it for nesting. Hagan et al. (1996), working in Maine, showed that increased bird abundances in forested areas adjacent to clearcuts were due to a crowding effect. Birds displaced from areas logged moved into adjacent uncut areas. Assuming these larger numbers meant the bird population was more viable would clearly be an erroneous conclusion. 
To assess bird viability, nest searching and monitoring has been developed in recent years. With this method, nests of the species of interest are located, and then tracked throughout the breeding season (Martin 1992, Martin and Geupel 1993). Nests are visited at regular intervals, and the fate of each nest recorded. From these data, survival estimates can be developed that serve as a measure of viability. Finding nests and tracking them to observe success or failure has proven a valuable tool in illustrating an area's true contribution to avian population viability.

I used nest searching and monitoring in the fragmentation study (Chapter 4). Details are presented in the nest searching section later in this chapter.

\section{Detailed Methods}

\section{Point Counts}

Selection of relatively large study areas $\left(25 \mathrm{~km}^{2}\right)$ allowed examination of landscape and forest type effects. I therefore examined whether abundance could be related to habitat at transect and point scales. Sampling transects were established within the study landscapes, and sampling points arranged along them. Finally, to examine riparian effects on bird abundance, riparian zones were sampled within each study landscape (Chapter 5).

In 1995, trial point count transects were established and the time necessary for each task documented. I used this information, in combination with knowledge of local terrain and travel constraints, to estimate the number of transects that could be sampled. Accordingly, in 1996, four sampling transects were established at random locations in each landscape (Appendix Table A-1, Fig. 3-2). Identical point count sampling methods were used in the landscape, fragmentation, and riparian studies. Once the transect starting point was identified, the transect was oriented to capture the maximum amount of forested landscape 
variation possible. This was accomplished through long transects (2500 $\mathrm{m}$ in length), oriented at right angles to contours in order to capture the maximum variation in elevation and landforms.

Sampling points for bird abundance counts were located at the start of each transect, and at 250-m intervals thereafter. A typical transect therefore contained 11 points, although this varied somewhat because of landscape constraints (Appendix Table A-1). To accommodate the riparian study (Chapter 5), one of the four transects was oriented along a first- or secondorder stream, with each sampling point within $50 \mathrm{~m}$ of the stream.

Because each transect had 11 points on average, each study area contained approximately 11 riparian points and 33 upland points. Although these numbers varied somewhat because of logistical constraints, I sought throughout to maintain approximately the same number of upland and riparian points per study area. Each point count center was geo-referenced with a Trimble global positioning system (GPS) unit (Trimble 1995).

At the point scale, bird abundance and richness were determined using standard 50-m radius point counts (Ralph et al. 1993), in accordance with the state network of point count sampling stations, administered by the West Virginia Division of Natural Resources. Sampling occurred during the breeding season (May 23-June 30) of 1996 and 1997. All birds heard or seen within a 10 -min period were tallied. Fly-overs were counted as within plots if they crossed the plot during the 10 -min period. Each point was sampled twice during the season with approximately 15 days between each sampling. For statistical analyses, I used the greater count of the two samples; e.g., if two red-eyed vireos were encountered on the first sampling at a point, and one on the second, the count for analysis purposes was two. Observers' ability to identify birds was verified in the field by a local expert. As recorded 
data came in from the field, they were spot-checked by crew supervisors for correct identification of species.

\section{Nest Searching and Monitoring Methods}

Because nest-searching is time- and labor-intensive, field sampling was limited to one forest type. The mixed mesophytic was chosen, because I hypothesized this would be the forest zone with the greatest bird diversity, and also because this type has been and will likely receive much of the future management impacts on the MNF.

In 1996, 40-ha nest search plots were co-located on two of the four point count transects within four of the six $5 \mathrm{~km} \mathrm{X} 5 \mathrm{~km}$ study areas. All nest search plots followed upland transects. Because nest search plots followed transects, they were $200 \mathrm{~m}$ wide and $2000 \mathrm{~m}$ long and were oriented at approximate right angles to contour lines. This approach was designed to capture the maximum environmental variation possible within logistical constraints. In 1997, more resources were available, and two nest-search plots were added at the Chestnut Ridge study area.

Nest searching followed the methodology of the national program of nest search plot monitoring (BBIRD 1996). Nests were located in the field, and then revisited at 3-4 day intervals throughout the nesting season (May 24-August 1 in 1996 and May 12-August 1 in 1997) until nestlings fledged or the nest was terminated through predation, abandonment, or adverse weather. The numbers of eggs or nestlings were recorded on each visit, as well as notes on parental location and behavior.

Observers avoided attracting predators to nests by keeping visits brief, and by using alternate approach routes on each visit. Nests were relocated by using a compass bearing and distance to a flagged grid location; flagging at nests was avoided whenever possible. 


\section{Vegetation Plots}

Data on vegetation plots were collected in July and August of 1996 and 1997. Vegetation plots were established both at point count stations (all studies) and for each nest known to have had eggs (fragmentation study only).

\section{Vegetation Plots for Point Counts}

For each 50-m radius point count plot, two 11.3 -m radius vegetation plots were sampled using modified methods of James and Shugart (1970). One plot was centered on the point count observation station; the other was located $30 \mathrm{~m}$ due north of the first plot center.

Variables measured included number of trees by diameter class, shrub counts, distance to edge, distance to water, canopy height, canopy percent cover, rhododendron (Rhododendron maximum L.) percent cover, percent canopy cover for each of six canopy layers, and percent conifer cover. Using a compass, aspect was also recorded for each plot. Elevation was obtained from a topographic map. Canopy height on the plot was measured using a clinometer. Percent cover of the conifer canopy (Barbour et al. 1980) was estimated for the understory and overstory layers of the 11.3-m-radius plot. This measure is a simple ocular estimate of the percent of ground area covered by the canopy layer.

Distance to edge and distance to water were ocularly estimated in the field, or for long distances, determined from a topographic map. Eight edge types were identified and recorded: paved road, open canopy dirt or gravel road, partially open canopy road, agricultural field, development (houses, etc.), clearcuts, wildlife openings, and natural forest gaps.

Canopy cover was also measured on four $11.3-\mathrm{m}$ transects placed at right angles to each other radiating from the plot center, but with a different method than for conifer cover 
estimates. At five 2.25-m intervals along each transect, canopy cover present in the crosshairs of a sight tube was recorded in each of six layers: $0.5-3 \mathrm{~m}, 3.1-6 \mathrm{~m}, 6.1-12 \mathrm{~m}, 12.1-$ $18 \mathrm{~m}, 18.1-24 \mathrm{~m}$, and greater than $24 \mathrm{~m}$. Canopy cover for each layer was calculated as the total number of contacts with vegetation (maximum of 20) on a plot. I also calculated a structural diversity index equal to the sum of all contacts in all layers.

Observers identified the plant association (habitat type) at each plot, using a list of plant indicators and their abundance in a dichotomous key. Plant associations vary with site productivity and diversity (Daubenmire 1978, Ferguson et al. 1989), and I hypothesized they might influence bird survival. The plant associations defined by DeMeo (1998) were used, based on the work of McCay et al. (1997). Aspect of each nest was measured with a compass.

\section{Vegetation Plots For Nests}

Following the nesting period, vegetation and other environmental data were collected at each nest using the BBIRD protocol and modified methods of James and Shugart (1970). Nest sites were sampled only after bird use of the nest had ended.

Observers established an 11.3-m radius plot centered on each nest, and collected the same data as at the point count centers. Additionally, diameter at breast height of all trees on the plot was measured with a diameter tape; trees then were tallied into diameter classes as follows: $2.5-8 \mathrm{~cm},>8-15 \mathrm{~cm},>15-23 \mathrm{~cm},>23-38 \mathrm{~cm}$, and $>38 \mathrm{~cm}$. Shrub stem density included both shrubs and trees less than $2.5 \mathrm{~cm}$ in diameter, and was tallied on a 5 -m radius plot coincident with the center of the $11.3-\mathrm{m}$ radius plot. 


\section{Data analyses}

\section{Bird groups}

For both point counts and nest searching, I analyzed all birds, the Partners in Flight (PIF) group of nine species (Partners in Flight 1998), and habitat, nesting, and foraging guilds. The list of PIF species was developed by a West Virginia Partners in Flight working group, and are sensitive species or species considered valuable indicators of ecosystem function. They include hooded warbler, red-eyed vireo (Vireo olivaceus), wood thrush (Hylocichla mustelina), worm-eating warbler (Helmitheros vermivorus), cerulean warbler, Louisiana waterthrush, scarlet tanager (Piranga olivacea), eastern wood peewee (Contopus virens), and Acadian flycatcher (Empidonax virescens). Habitat guilds were determined using Freemark and Collins (1992). Nesting and foraging guild membership was determined using Ehrlich et al. (1988).

\section{Point Count Data}

For analysis of point count data in landscape, fragmentation, and riparian studies, I used a variation of a split-plot analysis of variance (Petersen 1985). With this method, a secondary effect can be separated (or "split") from a main effect. In this way, the variation in bird abundance and species richness could be separated and identified at point, transect, and landscape scales. The error terms were defined as the nested effect of the higher scales in the hierarchy; e.g., for effects at the transect (middle) scale, the error term was the nested effect (interaction) of forest type, riparian status, and study area (block). See Appendix Table A-2 for further explanation of class variables. When an effect was significant $(p<0.10)$, means comparisons were performed with the Waller-Duncan k-ratio t-test. 
The response variables were bird abundance and species richness per point. I compared these using a variety of groupings: 1) all birds sampled; 2) nesting, migratory, foraging, and habitat guilds (Freemark and Collins 1992); and individual species of interest. Species of interest were the nine PIF species mentioned above, as well as the 10 most common species detected on point counts (Appendix Table A-3). In general, these groupings were used in analyses at all three scales (landscape, transect, and point).

\section{Landscape Scale}

At this scale I compared bird abundance/species richness response by forest type, year, and upland vs. riparian. Means comparisons were made with Duncan's test (Petersen 1985).

\section{Transect Scale}

A battery of analyses were used to relate environmental data to bird abundance and species richness. The habitat variables were distance to water (DTW), slope (SLOPE), aspect (ASPECTT), elevation above sea level (ELEV), overstory conifer cover (OSCON), understory conifer cover (USCON), combined overstory and understory conifer cover (SUMCON), stand height (STANDHT), and rhododendron cover (RHMA). Canopy cover was also used at each of six layers (CAN1, CAN2 ...CAN6). Finally, we included a structural diversity score (SDIALL) that reflected the sum of canopy covers for the six layers. Aspect data were transformed to a scale from 0 to 2 using the formula transformed aspect $=\cos ($ aspect-45) +1 (Beers et al. 1966). On this scale values near 1 indicate "northeastness," and hence cool, moist sites. Percent cover data were transformed using $\arcsin ($ square root of ( percent cover X 0.01)) (Zar 1984).

I first used correlation and principal components analysis (PCA) to reduce the list of variables. Principal components are formed when a correlation matrix of the variables is 
correlated again against the original variables. These components allow grouping of variables into environmental gradients (Kachigan 1986). I used PCA only to identify variables significantly contributing to variation in the components, hence eliminating others not significant. In subsequent regressions, I used original data values, and not PCA factor loadings.

At the transect scale, PCA was performed using the averages of each habitat variable for each transect. To clarify differences in variables along PCA axes, factor loadings were rotated. Components were rotated to further clarify differences between them. Variables showing the greatest importance for an axis were used in subsequent regression equations.

To explain variation in bird abundance/species richness between transects, I used stepwise multiple regression techniques to relate habitat variables to bird abundance and species richness. The average abundance/species richness per transect was used as a response variable to independent habitat variables, also using the average value per transect. At this scale, I organized abundance/richness data by: 1) all birds; 2 ) migratory, nesting, foraging, and habitat guilds, and 3) the top 10 species (by abundance) in each forest type.

Cerulean warblers (Dendroica cerulea), hooded warblers (Wilsonia citrina), Louisiana waterthrushes (Seiurus motacilla), and yellow-billed cuckoos (Coccyzus americanus) were rarely detected. For these less common species of interest, logistic regression was used, rather than stepwise regression. Logistic regression uses presence/absence as the response variable (in this case, count), and is effective with small sample sizes (Kachigan 1986). Analyses were only performed when data for at least five birds for a species were available for the forest type of interest. Brown-headed cowbirds were also included in the logistic regression analyses because of their adverse effect on songbird viability in fragmented 
landscapes (Brittingham and Temple 1983, Robinson et al. 1995). With these analyses, I sought some insight on their habitat relationships in intact landscapes.

\section{Point Scale}

The above PCAs and regressions were also performed at the point scale. In this case, response and independent variables for each point were used, rather than averaged for each transect. Procedures were otherwise identical.

\section{Nest Search Data Analysis}

Nest survival and clutch size data for 1996 and 1997 were combined. Nest survival estimates were calculated using the Mayfield method (Mayfield 1961, 1975, Hensler and Nichols 1981), using an assumed 15-day incubation period and 12-day brooding (nestling) period. Survival estimates for incubation and brooding periods were calculated separately, then multiplied together to determine breeding season (total) survival. Survival estimates were compared among study areas and nest search plots using CONTRAST, a program based on chi-square analyses (Hines and Sauer 1989). The variance for the survival estimates was calculated using $\mathrm{V}=\mathrm{sm} / \mathrm{E}$, where $\mathrm{V}=$ the variance, $\mathrm{s}=$ daily survival rate, $\mathrm{m}=$ daily mortality rate, and $\mathrm{E}=$ total days of nest exposure (Darveau et al. 1993).

Clutch sizes were compared among study areas and nest plots using analysis of variance, with the Duncan means comparison when effects were significant $(\mathrm{p}<0.05)$. A summary of all analyses are presented in Appendix Table A-4.

At the individual nest scale, logistic regression was used to predict nest outcome (success or failure) as the dependent variable, with distance to edge, plot core area, and distance to water as independent variables. Logistic regressions were also performed with nest success dependent on nest-site habitat variables (aspect, canopy height, canopy cover for six canopy 
layers, the structural diversity index, and tree diameter classes). In analyses with tree diameter data, I used only data in the $23 \mathrm{~cm}-38 \mathrm{~cm}$, and $>38 \mathrm{~cm}$ classes, reasoning that canopy cover measures (can1, can2, and3) served as accurate measures of stand structure for tree diameters less than $23 \mathrm{~cm}$.

To more accurately determine edge effects, distances to edge were weighted by edge type (Appendix Table A-5). Weights were based on nest survival data for different edge types (Chapter 4). In cases where data were not available for an edge type, I used data for the most similar type available.

To evaluate clutch size at the nest scale, stepwise regression was used to fit the best model possible. Clutch size was the dependent variable, with local fragmentation and on-site variables as independent variables. 


\section{Literature Cited}

Barbour, M.G., J.H. Burk, and W.D. Pitts. 1980. Terrestrial plant ecology. Menlo Park, CA: Benjamin/Cummings Publishing, 604 pp.

BBIRD. 1996. Breeding Biology Research and Monitoring Database (BBIRD) data entry program, version 0.9. Missoula, MT: Univ. of Montana Coop, 29 pp.

Brittingham, M. and S. Temple. 1983. Have cowbirds caused forest songbirds to decline? BioScience 33:31-35.

Burns, R.M., and B.H. Honkala, eds. 1990. Silvics of North America. Washington, DC: USDA For. Serv.

Clark Univeristy. 1995. Idrisi GIS software user's manual. Cambridge, MA: Clark University.

Core, E.L. 1966. Vegetation of West Virginia. Parsons, WV: McClain Printing Co., 217 pp.

Darveau, M., Gauthier, G., J.L. DesGranges, and Y. Mauffette. 1993. Nesting success, nest sites, and parental care of the least flycatcher in declining maple forests. Can. J. Zool. 71:1592-1601.

Daubenmire, R. 1978. Plant geography. New York: Academic Press, 338 pp.

DeMeo, T. 1998. Terrestrial ecological classification of the Monongahela National Forest, West Virginia. Elkins, WV: USDA For. Serv. Unpub. rep. on file.

Donovan, T.M., R.H. Lamberson, A. Kimber, F.R. Thompson III, and J. Faaborg. 1995. Modeling the effects of habitat fragmentation on source and sink demography of neotropical migrant birds. Conserv. Biol. 9(6):1396-1407.

Ferguson, D.E., P. Morgan, and F.D. Johnson. 1989. Proceedings- Land classifications based on vegetation: Applications for resource management. Ogden, UT: USDA For. Serv. Gen. Tech. Rep. INT-257, 315 pp.

Freemark, K., and B. Collins. 1992. Landscape ecology of birds breeding in temperate forest fragments. pp. 443-454 in J.M. Hagan III and D.W. Johnston, eds. Ecology and conservation of neotropical migrant landbirds. Washington, DC: Smithsonian Institution Press.

Hagan, J.M., W.M. vander Haefen, and P.S. McKinley. 1996. The early development of forest fragmentation effects on birds. Conserv. Biol 10(1):188-202. 
Hensler, G.L., and J.D. Nichols. 1981. The Mayfield method of estimating nesting success: a model, estimators and simulation results. Wilson Bull. 93(1):42-53.

Hines, J.E., and J.R. Sauer. 1989. Program CONTRAST: A general program for the analysis of several survival or recovery rate estimates. USDI Fish and Wildl. Serv. Tech. Rep. 24.

James, F.C., and H.H. Shugart, Jr. 1970. A quantitative method of habitat description. Audubon Field Notes 24(6):727-736. Wildl. Res. Unit, 27 pp.

Kachigan, S.K. 1986. Statistical analysis. New York: Radius Press, 589 pp.

Kuchler, A.W. 1964. Map and manual, potential natural vegetation of the coterminous United States. Amer. Geog. Soc. Special Publ. No. 36, 156 pp.

Martin, T.E., and G.R. Geupel. 1993. Nest-monitoring plots: methods for locating nests and monitoring success. J. Field Ornithol. 64(4):507-519.

Mayfield, H.F. 1961. Nesting success calculated from exposure. Wilson Bull. 73:255-261.

Mayfield, H.F. 1975. Suggestions for calculating nest success. Wilson Bull. 87(4):456-466.

McGarigal, K., and B.J. Marks. 1995. FRAGSTATS: spatial pattern analysis program for quantifying landscape structure. Gen. Tech. Rep. PNW-GTR-351. Portland, OR: USDA For. Serv., Pacific Northwest Research Station, 122 pp.

McNab, W.H., and P.E. Avers. 1994. Ecological subregions of the United States: Section descriptions. Washington, DC: USDA For.Serv. Pub. WO-WSA-5.

Partners in Flight. 1998. Newsletter of the West VirginiaPartners in Flight Working Group. Elkins, WV, Spring 1998.

Petersen, R.G. 1985. Design and analysis of experiments. New York: Marcel Dekker, 429 pp.

Ralph, C.J., G.R. Geupel, P. Pyle, T.E. Martin, and D.E. DeSante. 1993. Handbook of field methods for monitoring landbirds. Gen. Tech. Rep. PSW-GTR-144. Albany, CA: Pacific Southwest Res. Sta., USDA For. Serv.

Robinson, S., S. Rothstein, M. Brittingham, L. Petit, and J. Grybowski. 1995. Ecology and behavior of cowbirds and their impact on host populations. In T. Martin and D. Finch, eds., Ecology and management of Neotropical Birds: A synthesis and review of critical issues. Oxford University Press, New York.

Temple, S.A., and J.R. Cary. 1988. Modeling dynamics of habitat-interior bird populations in fragmented landscapes. Conserv. Biol. 2(4):340-347. 
Trimble. 1995. Trimble Explorer user's guide. Trimble Corp., Sunnyvale, CA.

White, P.S., and C.V. Cogbill. 1992. Spruce-fir forests of eastern North America. pp. 3-39 in C. Eagar and M. B. Adams, eds. Ecology and decline of red spruce in the eastern United States. New York: Springer-Verlag, 417 pp.

Zar. 1984. Biostatistical analysis. Englewood Cliffs, NJ: Prentice-Hall. 


\section{Chapter 3. Relating Forest Songbird Abundance to Habitat at Multiple Scales on the Monongahela National Forest, West Virginia}

Abstract. I investigated songbird-habitat relationships at multiple scales in four major forest types of the Monongahela National Forest, West Virginia. Landscape $\left(25 \mathrm{~km}^{2}\right)$, transect $(2500 \mathrm{~m})$, and point $(50-\mathrm{m}$ radius point count plot) scales were used in a nested design. To investigate the nature of large intact tracts, dispersed landscapes with a minimum of 60 percent core area were selected.

At the landscape scale, forest types differed in bird abundance $(\mathrm{p}=0.07)$ and species richness $(\mathrm{p}=0.08)$. Mixed mesophytic and red spruce forest types showed the greatest bird abundance and species richness $(\mathrm{p}<0.05)$. Abundance of forest-interior species, Neotropical migrants, and nine key indicator species were greatest in the mixed mesophytic $(\mathrm{p}<0.05)$. Bird abundance and species richness differences at the transect scale were significant $(\mathrm{p}<0.001)$ and were related to differences in stand height and canopy structure. Relatively little variation in bird abundance or richness occurred between points within a transect, even though transects were oriented to capture the maximum variation in elevation.

Environmental variables explained much more variation at the transect than at the local scale.

Although bird species viability cannot be inferred from point counts, results suggest that this national forest is providing abundant habitat for interior species. Forest managers selecting reserve areas for songbird conservation should consider the relative importance of the mixed mesophytic, especially for neotropical migrants, and seek to maintain the diversity of natural forest habitats across the Monongahela landscape. 


\section{Introduction}

The abundance and viability of forest songbirds has become a concern in the eastern United States, based on declines identified from breeding bird survey (BBS) data (Peterjohn and Sauer 1994), and in studies of forest fragmentation effects on birds (Askins et al. 1990, Robinson 1992, Robinson et al. 1995a). While information on bird-habitat relationships has accumulated in fragmented landscapes (Temple and Cary 1988, Robinson 1992, Freemark and Collins 1992, Dawson et al. 1993, Donovan et al. 1995a, b), relatively intact landscapes have received less research attention.

Multiple scales must be considered in planning for the viability of wildlife populations (Harris 1984, Noss and Cooperrider 1994, Freemark et al. 1995). Management of species at the local (e.g., forest stand) scale is no longer considered adequate (Kessler et al. 1992, Freemark et al 1995), because ecosystem processes and habitats are linked (Harris 1984, Soule and Simberloff 1986, Simberloff 1988, Noss 1992). What happens in areas adjacent to the habitat of concern matters (Thomas et al. 1990).

An understanding of how landscape pieces fit together is essential to any management plan for the viability of species (Noss 1983, Noss and Cooperrider 1994, Trani and Giles 1999). Spatial patterns can be used to explain species distributions (Burgess and Sharpe 1981, Freemark et al. 1995), because all habitat is not of equal value to wildlife, and because some species are particularly affected by landscape configuration. For example, species that cannot maintain viability over time in small patches are known as area-sensitive or interior species. 
To organize assessment of diversity at mutliple scales, Whittaker (1960) coined the terms alpha, beta, and gamma diversity. Alpha diversity is the variety of life at the local scale; e.g., the number of species in a forest stand. Beta diversity reflects changes across the landscape. For example, contiguous, uniform pine plantations across a landscape have less beta diversity than a mosaic of clearcut and forested areas. Finally, gamma diversity is broadscale or regional in scope. Note that changes at one scale can affect diversity at another scale. For example, increases in beta diversity through staggered-setting clearcutting of a forested landscape can potentially reduce regional, or gamma, diversity by reducing habitat and viability of forest interior-dependent species.

Freemark et al. (1995) outlined how these concepts relate to migratory songbirds. Habitat selection by neotropical migrants involves response to habitat pattern at hierarchical levels, including the territory, patch, and landscape. All habitats are not of equal quality, since birds tend to select some over others because of better opportunities for feeding, successful reproduction, and dispersal. Consideration of multiple scales is also necessary so that sets of local populations linked by dispersal (metapopulations) (Merriam 1988, Pulliam 1988) can interact.

Forests of the Central Appalachians, notably those of the Allegheny Plateau, are thought to provide important summer breeding habitat for songbirds. In an analysis of the relative value of physiographic provinces for songbird populations, Rosenberg and Wells (1995) ranked the Allegheny Plateau among the top five provinces for 28 of 34 species of interest. Further, they ranked West Virginia and adjacent highland areas of Maryland as a "major area of high importance." 
The Monongahela National Forest (MNF) covers 367,611 ha of east-central West Virginia, in the heart of a region thought to be an important source area for migratory songbirds, particularly those associated with forest-interior and interior-edge conditions. Information on songbird-habitat relationships will be of critical importance in the Forest's administration, since a comprehensive Forest plan revision is slated to begin in the near future.

\section{Objectives}

My objective in this study was to compare bird abundance and species richness at three nested scales (landscape, transect, and point). Further, if differences in bird response were found, I sought to identify the habitat features associated with these differences.

Objectives at each scale were: 1) to compare forest songbird abundance and diversity among four major forest types: dry oaks, mixed mesophytic, northern hardwoods, and red spruce; 2) to compare bird abundance between sampling transects and to identify habitat factors explaining significant differences in abundances between transects; and 3) to develop bird-habitat relationships with site variables of slope, stand height, aspect, elevation, vegetation cover, and vegetation structural diversity.

\section{Study Areas}

In 1996, three study areas, each $25 \mathrm{~km}^{2}$, were randomly selected for each of the four major forest types on the Monongahela National Forest (mixed mesophytic, northern hardwoods, dry oaks, and red spruce) (Appendix Table A-1). Mixed mesophytic forests are characterized by sugar maple (Acer saccharum) and red oak (Quercus rubra), typically at elevations below $900 \mathrm{~m}$ in the Allegheny Mountains (Core 1966). Northern hardwoods 
occur at higher elevations (900 to $1150 \mathrm{~m}$ ), are generally less productive, and are characterized by American beech (Fagus grandifolia). Red spruce (Picea rubens) forest occurs at the highest elevations ( 1150 to $1240 \mathrm{~m}$ ) and is characterized by cold soils and a relatively short growing season. Dry oaks, in contrast to the other three types, predominate in the eastern (Ridge and Valley) portion of the Monongahela, which has a markedly drier climate, thus limiting forest productivity. Vegetation there is characterized by white (Quercus alba) and chestnut oak (Quercus prinus), with scarlet (Quercus velutina) and black oaks (Quercus coccinea) on drier sites, and the "dry pines" (table mountain (Pinus pungens), pitch (Pinus rigida), and Virginia pine (Pinus virginiana)) on the poorest sites. (See Chapter 1 for more complete descriptions of forest types.)

Although precise areas of each forest type are not known, northern hardwoods are the most common type on the MNF, followed by mixed mesophytic and dry oaks in roughly equal proportions. Red spruce is the least common of the four types, and has been greatly reduced from its pre-settlement area by turn-of-the-century logging and subsequent fires (Stephenson 1993).

Because I was interested in studying bird habitat in relatively intact areas typical of the MNF, I selected 60 percent core area as a minimum for the study areas. I hypothesized these areas would function as intact forests for interior songbird species. Core area was calculated as forest area minus a 100-m edge width (Temple and Cary 1988).

I verified core areas using FRAGSTATS (McGarigal and Marks 1995), a widely-used fragmentation analysis package. LANDSAT images from July 1992 were used as the data 
source; images were converted from false-color composites to open-versus-forested images using an unsupervised classification technique (Clark University 1995).

Open areas in these landscapes varied, and included pastures, broad, low energy riparian zones, some housing development, road networks, natural forest gaps, and regenerating clearcuts about 4 to 8 ha in area. Roads included highway corridors but mostly secondary and unimproved roads. Regenerating clearcuts were dispersed along road networks, and generally filling in with dense shrub/tree regeneration varying from 1 to $10 \mathrm{~m}$ in height. This regeneration came from both stump-sprouting and seeding in of invasive species such as red maple (Acer rubrum) and black locust (Robinia pseudoacacia).

Forest fragmentation in the study areas thus included both relatively permanent (pastures and development) and temporary (regenerating clearcuts and natural forest gaps) fragmentation. Most areas in the vicinity of transects were either contiguous forest or secondary roads/regenerating clearcuts.

At the landscape scale, I randomly selected three $5 \mathrm{~km} \mathrm{X} 5 \mathrm{~km}$ study areas (each with a minimum of 60 percent core area) in each of the four major forest types (mixed mesophytic, northern hardwoods, red spruce, and dry oaks), for a total of 12 study areas.

\section{Methods}

\section{Experimental Design}

Within each landscape, four transects per study area were sampled, three upland and one riparian. I included one riparian transect out of four as a rough estimate of riparian abundance across the landscape; otherwise riparian areas would likely be undersampled and the landscape misrepresented. Because most transects contained 11 points (a few ranged 
from 7-18 points), each study area contained approximately 33 upland points and 11 riparian points. Although these numbers varied somewhat because of logistical constraints, I maintained approximately the same proportion of upland and riparian points per study area.

At the transect scale, sample points were nested along transects $2500 \mathrm{~m}$ in length, with a point at the transect start, and subsequent points at 250-m intervals (Appendix Table A-1). To obtain a broad scope of inference, I oriented transects at right angles to contour lines, thus capturing variation due to elevation. Riparian transects were also typically composed of 11 points, but followed first or second order streams. All sampling took place within $50 \mathrm{~m}$ of streams.

At the point scale, bird abundance (the total number of birds) and richness (the total number of species) were measured using standard 50-m radius point counts (Ralph et al. 1993). Sampling occurred twice during each breeding season (May 23-June 30) in 1996 and 1997.

\section{Site Data}

For each 50-m radius point count plot, two 11.3-m radius vegetation plots were sampled using methods modified from James and Shugart (1970). Variables measured included distance to water, canopy height, canopy percent cover, rhododendron (Rhododendron maximum) percent cover, site aspect, elevation, canopy cover for each of six canopy layers, and percent conifer cover. Aspect at each point was measured with a compass. Distance to water was ocularly estimated in the field, or for long distances, determined from a topographic map. Canopy cover for each of six canopy layers was determined using a sighting tube (James and Shugart 1970). 
Observers identified the plant association (habitat type) at each point, using a list of plant indicators and their abundance in a dichotomous key (DeMeo 1998). Plant associations vary with site productivity and diversity of forest stands (Daubenmire 1978, Ferguson et al. 1989), and might explain variation in bird abundance and species richness. I used the plant associations defined by DeMeo (1998), based on the work of McCay et al. (1997).

\section{Data Analysis}

Most analyses were performed with SAS (SAS Institute 1988). Principal components analysis (PCA) and some means comparisons were performed with JMP (SAS Institute 1995). Differences were considered significant at alpha=0.10. For stepwise multiple and logistic regressions, variables entered models at $\mathrm{p}=0.15$.

For analyses at multiple scales, I used a variation of a split-plot analysis of variance (Petersen 1985) (Appendix Tables A-2 and A-4). This allowed the variation in bird abundance and species richness to be separated and identified at point, transect, and landscape scales. The error terms were defined as the nested effect of the higher scales in the hierarchy; e.g., for effects at the transect (middle) scale, the error term was the nested effect (interaction) of forest type, riparian status, and study area (block).

Response variables were bird abundance and species richness per point. I compared these using a variety of groupings: 1) all birds sampled; 2) nesting, migratory, foraging, and habitat guilds (Freemark and Collins 1992); and 3) individual species of interest. For species of interest, I used nine species considered monitoring indicators by the West Virginia Partners in Flight (PIF) initiative (Partners in Flight 1998): cerulean warblers (Dendroica cerulea), 
worm-eating warblers (Helmitheros vermivorus), red-eyed vireos (Vireo olivaceus), wood thrushes (Hylocichla mustelina), hooded warblers (Wilsonia citrina), Acadian flycatchers (Empidonax virescens), Louisiana waterthrushes (Seiurus motacilla), scarlet tanagers (Piranga olivacea), and eastern wood peewees (Contopus virens), as well as the 10 most common species detected on point counts (Appendix Table A-3).

\section{Landscape Scale}

At this scale bird abundacne and species richness were compared between forest types using analysis of variance and means separation procedures outlined above. My objective here was to investigate differences (gamma diversity) across the forest zones of the MNF.

\section{Transect Scale}

At the transect scale, I sought to clarify bird diversity across the study areas, with particular reference to the changes in environmental factors from one transect to another (beta diversity). I conducted a sequence of analyses to relate environmental data to bird abundance. The habitat variables were distance to water (DTW), slope (SLOPE), aspect (ASPECTT), elevation above sea level (ELEV), overstory conifer cover (OSCON), understory conifer cover (USCON), combined overstory and understory conifer cover (SUMCON), stand height (STANDHT), and rhododendron cover (RHMA). I also used canopy cover at each of six layers (CAN1, CAN2...CAN6). Finally, I included a structural diversity score (SDIALL) reflecting the sum of canopy covers for the six layers. Aspect data were transformed to a scale from 0 to 2 using the formula transformed aspect $=\cos ($ aspect -45$)$ + 1 (Beers et al. 1966). On this scale values near 1 indicate "northeastness," and hence cool, moist sites. Percent cover data were arcsin square root transformed (Zar 1984). 
I first used correlation and principal components analysis (PCA) to identify redundant variables. Principal components are formed when a correlation matrix of the variables is correlated again against the original variables. These components allow grouping of variables into environmental gradients (Kachigan 1986). I used PCA to identify variables significantly contributing to variation in the components, hence eliminating others not significant. PCA was performed using the averages of each habitat variable for each transect. To clarify differences in variables along PCA axes, factor loadings were rotated. Variables showing the greatest importance for an axis were used in subsequent regression equations. To explain variation in bird abundance between transects, I used stepwise multiple regression techniques to relate habitat variables to bird abundance. For each forest type, I grouped birds as all birds, by migratory guilds, and by habitat guilds. I also used average abundance per transect for the ten most abundant species in each forest type (Appendix Table A-3). Bird abundance was used as a response variable to independent habitat variables, using the average value per transect.

Cerulean warblers, hooded warblers, Louisiana waterthrushes, and yellow-billed cuckoos were rarely detected (Appendix Table A-7). For these less common species of interest , logistic regression was used, rather than stepwise regression. Logistic regression uses presence/absence as the response variable (in this case, count), and is effective with small sample sizes (Kachigan 1986). Analyses were only performed when data for at least five birds for a species were available for the forest type of interest (Appendix Table A-7).

Brown-headed cowbirds were also included in the logistic regression analyses because of their adverse effect on songbird viability in fragmented landscapes (Brittingham and Temple 
1983, Robinson et al. 1995). With these analyses, I sought some insight on their habitat relationships in intact landscapes.

\section{Point Scale}

At the point scale, I sought to identify bird-habitat relationships with site variables of slope, stand height, aspect, elevation, vegetation cover, and vegetation structural diversity. To accomplish this, regressions and PCAs were used, with procedures similar to those at the transect scale. In this case, response and independent variables for each point were used, rather than averaged for each transect. Procedures were otherwise identical.

\section{Results}

\section{Landscape Scale}

The four forest types differed in forest composition and structure, but not for all variables (Appendix Table A-6). Mixed mesophytic and dry oak forests featured the steepest slopes. Conifers were well-represented in all types except mixed mesophytic. Mixed mesophytic sites were the tallest and most structurally diverse. Northern hardwood sites had the most understory cover. No significant differences $(\mathrm{p}<0.05)$ between forest types were found in the canopy layers ranging from $3 \mathrm{~m}$ to $18 \mathrm{~m}$ above the ground.

For all birds as a group, significant effects for both bird abundance and species richness included year of sampling, upland vs. riparian effect, and transect (Table 3-1). Forest type significantly affected both abundance $(\mathrm{p}=0.08)$ and species richness $(\mathrm{p}=0.07)$. On average, more birds (7.5 vs. 6.0, $\mathrm{F}=93.2, \mathrm{p}<0.05)$ and more species $(6.3$ vs. $4.8, \mathrm{~F}=162.3, \mathrm{p}<0.05)$ were encountered in 1997 than in 1996. Birds were most abundant and diverse in mixed 
mesophytic and red spruce forest types $(\mathrm{p}<0.05)$. Red spruce, dry oaks, and northern hardwoods did not differ in bird abundance and species richness ( $\mathrm{p}>0.10$, Table 3-2).

Forest type affected species richness and abundance (Table 3-2) primarily in nesting and habitat guilds. For nesting guilds, abundance and richness of low canopy and shrub species tended to be higher in the mixed mesophytic, while richness and abundance of groundnesting species was greatest in the dry oaks. Red spruce and mixed mesophytic forest was associated with greater abundance and richness of high canopy species. Low canopy and shrub species were clearly more abundant in the mixed mesophytic. Abundance and richness of cavity nesters did not differ among forest types.

Neotropical migrants were more abundant in mixed mesophytic forest (an average of about two to three birds more per point than other types). No differences were found between forest types for short-distance migrants or resident species.

Foraging guild was of little value in comparing forest types (Table 3-2); only mixed foragers showed differences between forest types with both richness and abundance varying among forest types.

For habitat guilds (Table 3-2), the mixed mesophytic and red spruce types showed the greatest abundance and number of species in the forest interior guild. Interior-edge species were most abundant in the mixed mesophytic and dry oaks; the number of interior-edge species was significantly lower in northern hardwoods. Richness of edge species was greater in the mixed mesophytic than in other forest types; while abundance of edge species was greatest in the mixed mesophytic and northern hardwoods. 
Of the nine species identified by West Virginia Partners in Flight as valuable indicators of bird abundance, four species (Cerulean warbler, red-eyed vireo, wood thrush, and Acadian flycatcher) had highest abundance in the mixed mesophytic (Table 3-2). For all species except one, mixed mesophytic sites were at least equal to the greatest number of birds found. Worm-eating warblers were significantly greater $(\mathrm{p}<0.5)$ in dry oaks. Hooded warbler abundance did not differ among forest types.

\section{Transect Scale}

Difference of bird abundance/richness among transects was significant $(\mathrm{p}=0.0001$, Table 3-1). The variation between points along transects was relatively small (mean square for richness $=4.9$ ), while variation between transects was high (mean square $=17)$. Since transects were designed to capture the greatest elevation gradient, relatively high variation between points was expected.

To relate these habitat differences to bird abundance at the transect scale, principal components analysis (PCA) identified variables for use in subsequent regression equations (Appendix Table A-8). For all four forest types, the first principal axis (PC I) identified forest stands with open understories (negative correlation with understory covers CAN1 and CAN2, and sometimes other layers as well). These sites also tend to be more productive, as evidenced by positive correlation with stand height (except for dry oaks). This axis accounted for 29-34 \% of the variation in bird abundance, depending on forest type.

The second axis (PC II) represents riparian zones, as evidenced by negative correlation with distance from water. Again the exception is the dry oak type, where riparian zones are described by PC III. The mixed mesophytic PC II also shows strong affinity with conifers 
(OSCON and SUMCON). Conifers (notably eastern hemlock, Tsuga canadensis) are common in riparian zones of the mixed mesophytic. In contrast, northern hardwood PC II indicated absence of conifers (as well as lower elevations and northeastern aspects). Red spruce PC II was different still, indicating high structural diversity (SDIALL) and tall trees (STANDHT), as well as proximity to water.

The third and fourth axes in each forest type (PCs III and IV) are less consistent in meaning, ranging from high elevation sites on PC IV in mixed mesophytic, to ambiguous results for PCIII in northern hardwoods, to diverse understories for PC IV in red spruce.

\section{Point Scale}

Habitat differences were also compared on an individual point basis. At the point scale, PC axes were associated with different habitat variables than at the transect scale (Appendix Table A-9). PC I was associated with conifers in all four forest types. In mixed mesophytic forest, it was also associated with structurally diverse stands (strong positive values for SDIALL and canopy layers 3-5) and proximity to water (negative Dist to Water). In contrast, northern hardwood PC I values are strongly associated with upland sites (positive Dist to Water), lack of overall structurall diversity (low SDIALL value, and strong assocition with canopy layers 2 and 3. Red spruce was characterized by a lack of structural diversity (negative values for SDIALL and all canopy layers except 6). Dry oaks were characterized as stands with high amounts of mid-story and overstory canopy, but little understory (negative values for canopy layers 1-3 and positive values for layers 4-6).

PC II represented tall stands with diverse high canopies (layers 5 and 6) in all forest types (Appendix Table A-9). PC III represented upland sites with diverse understories in the 
mixed mesophytic, tall stands with strong conifer components in northern hardwoods, diverse understories in red spruce (positive canopy layers 1 and 2), and conifers and structural diversity (positive SDIALL and canopy layers 1-4) in dry oaks. PC IV interpretations were inconsistent from one forest type to another.

Overall bird abundance and species richness was not significantly related to plant associations at the point scale (e.g., mixed mesophytic bird abundance: $F=0.27, p=0.90$; dry oaks bird abundance: $\mathrm{F}=1.55, \mathrm{p}=0.19$ ). An exception was species richness in dry oaks $(\mathrm{F}=2.12, \mathrm{p}=0.08)$, where inclusions of mixed mesophytic and northern hardwood plant associstions showed greater numbers of birds.

\section{Comparison of Bird Abundance Between Scales}

Comparing bird abundance and species richness between scales was the primary objective of this study. At the landscape scale, clear differences between forest types were evident. Mixed mesophytic forest emerged as the type with greatest abundance of Neotropical migrants, forest interior birds, and the Partners in Flight indicator species.

At transect and point scales, comparison of bird abundance response shows more subtle differences (Table 3-3). In mixed mesophytic forest, forest structural variables (low canopy layers and structural diversity) were generally more important indicators of bird abundance at the transect scale, while at the local (point) scale elevation and high canopy cover were better determinants.

For northern hardwoods there were no clear differences between transect and point scales. In contrast, red spruce showed many more significant abundance-habitat relationships at the transect scale than at points. Bird abundance of all birds, neotropical migrants, forest 
interior species, and interior-edge species were favored by upland sites (positive distance to water (DTW)) and taller forest stands. At the point scale in red spruce there were few significant relationships (Table 3-3).

In dry oaks relationships were similar at the transect and point scales. Few significant habitat relationships were identified, except for forest interior and interior-edge species. These species were associated with the absence of the highest canopy layer (CAN6) at the transect scale. At points, interior-edge species were associated with the shrub layer (CAN1), but forest interior birds avoided this layer (significant -CAN1).

More variation in bird abundance was explained between transects than between points (Tables 3-3 and 3-4), confirming findings in the initial analysis of variance for this study. Variables significantly explaining bird abundance varied between scales. For example, for Acadian flycatchers (ACFL) at the transect scale (Table 3-4), flycatcher abundance was significantly related to high canopies (CAN6) and the absence of a shrub layer (-CAN1). At the point scale, flycatchers were instead associated with proximity to water (-DTW) and conifer cover (SUMCON). Some species, such as black-capped chickadees (BCCH), had many variables significantly related to their occurrence at the point scale, and only one at the transect scale.

At the point scale, results of logistic regression analyzes to assess similar habitat-bird abundance relationships for selected uncommon species are presented in Appendix Table A10. In the mixed mesophytic, brown-headed cowbirds were associated with conifer cover. Cerulean warblers avoided streams, were associated with southern aspects, favored canopy 
layer 4 and avoided canopy layer 6. Louisiana waterthrushes were associated with streams and with structural diversity (canopy layers 2, 5, and overall).

In northern hardwoods, hooded warblers were associated with canopy class 4 and rhododendron, and avoided canopy class 6 . Brown-headed cowbirds were associated with steeper slopes and tall trees, but avoided canopy layer 6. Louisiana waterthrushes avoided the shrub layer.

In red spruce, hooded warblers avoided streams and tall trees, and were associated with higher elevations.

In the dry oaks, cowbirds were found on gentler slopes and avoided canopy layer 2. Hooded warblers favored higher elevations and canopy layer 3. Cerulean warblers favored steep slopes. Louisiana waterthrushes favored steep slopes and low elevations, and avoided south aspects.

\section{Discussion}

Recall the objective of this study was to compare bird abundance and species richness response between the landscape, transect, and point scales. Clear differences in bird response between scales emerged, notably the importance of variation at the transect scale. In the following sections I discuss the specific differences at each scale, followed by a comparison of the scales.

\section{Landscape Scale}

Of the four major forest types, mixed mesophytic and red spruce emerged as those with the greatest bird abundance and species richness. Mixed mesophytic forest, on average, represents the most productive forest on the Monongahela landscape because of lower 
elevations and richer soils. Of the 15 guilds investigated, eight had highest abundance in the mixed mesophytic (sometimes tied with another forest type); of the other seven, five showed no difference between any types. Of particular note is the association of mixed mesophytic with neotropical migrants - an average of 5.7 species and 7.4 birds per point, contrasted with the next most abundant set (red spruce), at 4.1 species and 4.6 birds per point. This means an average of nearly two more species and about three more birds per point, when compared with the next most abundant set.

Of further interest to conservation is the value of this forest type for indicator and rare species. Of the species on the West Virginia Partners In Flight list, the mixed mesophytic showed the greatest (or tied for greatest) abundance for seven of nine species (Table 3-2).

The MNF in general is in a mid-late successional sere following 80-100 years of regrowth since extensive turn-of -the-century logging (Stephenson 1993, McCay et al. 1997). Although the natural pattern of disturbance in this landscape is frequent small-scale windthrow (Meier et al. 1996), my data suggest the more productive mixed mesophytic areas sampled have not yet begun the natural stand break-up phase described by Oliver and Larson (1996). As evidenced by PCA Axis I (Appendix Table A-8) for mixed mesophytic transects, these are tall stands with a relatively depauperate understory. Because this axis alone explained 34 percent of the variation in mixed mesophytic bird abundance, this is evidence that greater bird abundance is associated with these productive stands-even though their structural diversity is relatively low.

Reasons for more bird abundance and species richness in red spruce are less evident. One factor may be the marked landscape heterogeneity of this type. Red spruce seldom occurs in 
large contiguous patches on the Monongahela landscape, and instead is interspersed with beech and yellow birch stands. Indeed, in selecting the study areas it was difficult to find 25 $\mathrm{km}^{2}$ areas that could be considered red spruce. This vegetative diversity may in turn be generating a diversity of bird species. In general, however, the abundance and species richness of birds in red spruce is surprising, given the high elevation, cold nature of this ecosystem.

Bird abundance in northern hardwoods and dry oaks was low compared with the other two forest types. Northern hardwood sites are limited by cooler temperatures, and dry oaks by lack of moisture.

\section{Transect Scale}

At this scale my objective was to identify a transect effect, if present, and if present, to identify the habitat variables contributing to the variation.

Variation in bird abundance at the transect scale was indeed significant $(\mathrm{p}<0.001)$, and explained in part by environmental variables (Tables 3-3 and 3-4). Environmental gradients in elevation are pronounced in the mixed mesophytic and dry oaks.

This diversity in environmental variables was related to bird abundance. For all four forest types, the first principal components axis (PC I) represented tall stands lacking understory layers (CAN 1 and CAN2, up to $6 \mathrm{~m}$ height). This axis explained about one-third (29-34\%) of the variation in bird abundance in the four forest types.

These are productive stands that have not yet experienced much canopy break-up. Recall that most of what is now the MNF was logged during 1880-1920; consequently stands today 
have probably reached their maximum height but are still young enough that windthrow and other disturbances have not yet begun to create significant amounts of canopy gaps.

This presents an interesting finding that suggests site productivity, rather than structural diversity, may be more important in driving bird abundance. Since MacArthur's (1958) work linking warblers to structural diversity, the importance of structural diversity has been considered an important factor driving bird abundance and diversity. My findings are a reminder that the importance of structural diversity is not always paramount. In fairness, it should be noted that structural diversity described the second principal component (PC II) in the red spruce forest type.

Within the four forest types, there were marked differences in the bird-habitat associations. Neotropical migrants, for example, were often associated with open forest understories (negative CAN1 and CAN2 values), but this varies with forest type. Some species have straightforward associations, such as the proximity of Acadian flycatchers to water (Table 3-4); others, such as black-and-white warblers, were difficult to associate with the habitat variables I measured. The appropriate variables may have been missed, or these species may be functioning as generalists in the MNF landscape.

\section{Point Scale}

My objective at this scale was to relate bird abundance and species diversity to site variables: slope, stand height, aspect, etc. In this I found relatively few cases where local site variables had a strong effect on bird occurrence. As with the transect scale, there was a great deal of variety in bird-habitat relationships, but both the variables and the magnitude of their effects were different. 
The variables important at this scale differed from those at the transect scale. At the transect scale, tall stands with open understories described PC I for all forest types. In contrast, at the point scale PC I was associated with conifer presence in all forest types. PC I's implications were not as clear as at the transect scale, however. In addition to conifers, structural diversity was important (in mixed mesophytic), lack of structural diversity (in northern hardwoods and red spruce), and tall stands with open understories (in dry oaks). The second principal component (PC II) represented tall stands with open understories.

The magnitude of variation in bird abundance at the point scale was much less than at the transect scale. $\mathrm{R}^{2}$ values for point-bird abundance relationships typically ranged from 0.01 to 0.06 , whereas with transects a variable often shows an $r^{2}$ of 0.25 or greater. Differences in bird response between points on a transect were small. Because transects were deliberately designed to capture the maximum variation possible in elevation (and inadvertently differences in landforms and aspects as well), this is somewhat surprising.

\section{Comparison of scales}

When comparing results between the scales, several key findings emerge. At the landscape scale, clear differences in the relative value of the forest types are evident. The mixed mesophytic showed the greatest number of neotropical migrants, interior species, and the Partners in Flight indicator species as a group.

The greatest variation of the three scales was at the transect scale $(\mathrm{p}<0.001)$, implying great beta diversity across the landscape. This may be due to the great variation in elevation, landforms, soils, and habitats across this highly-dissected mountain landscape. The relative 
lack of variation between points along a transect is surprising, particularly since transects were oriented to capture the maximum variation in elevation.

\section{Variation from year to year}

Although a greater number of birds were recorded in 1997 than in 1996, individual species often did not differ between years. When species are ranked by abundance, the rank order changes little from 1996 to 1997 . Blake et al. (1994), working in northern Michigan and Wisconsin, showed significant yearly variation in bird abundance was common, and was due in part to weather fluctuations. Our study areas received exceptional rainfall in 1996, and this may have affected bird abundance when compared with 1997, a more typical year.

\section{Intact Landscapes}

The final theme emerging from our results was to confirm the intact nature of the landscapes I studied. This was similar to McGarigal's (1993) results in the Oregon Coast Range, where only winter wren showed a significant correlation with forest interior. In this study, winter wren showed the strongest and most consistent association with forest interior. Forest interior birds were the most abundant, followed by interior edge and edge guilds.

\section{Conservation Implications and Recommendations}

Several clear implications emerge from this work. One is that the MNF is providing substantial habitat for a diversity of bird species, including forest interior species. This is similar to the results of several other studies in relatively intact landscapes, including Buford and Capen (1999) (Vermont), Thompson et al. (1992) (Missouri), and Welsh and Healy (1993) (New Hampshire). 
Unlike other study areas, however, the elevational and climatic differences inherent in the Monongahela landscape generate clear differences in the relative value of forest types. Mixed mesophytic forest showed significantly greater numbers of Neotropical migrants than the other types, and showed high numbers of birds in nearly every guild category (Table 3-2). This forest type should be the focus of areas to be retained for maintaining bird viability. The great variation in bird abundance and species richness between transects means diversity needs cannot be met at the local scale. The high diversity across the landscape (gamma diversity) means planning should retain connections between forested sites across the forest.

Habitat relationships at transect (across-landscape) and point (local) scales can be discerned from Tables 3-3 and 3-4. For example, in the mixed mesophytic, neotropical migrants, are associated with lower elevation sites. In northern hardwoods, they are associated with upland sites lacking conifers and the first canopy layer $(0.5-3 \mathrm{~m})$. In red spruce, differences between stand heights and structural diversity between transects affect neotropical migrant abundance, but at the point scale, only upland (versus riparian) have an effect. In dry oaks, neotropical migrants avoid canopy layer six (>24 m height) in mixed mesophytic, but avoid canopy layer 5 (18.1-24 m) in dry oaks. Specific management recommendations are therefore as follows:

1. Although population viability cannot be infered from point counts, results imply the $\mathrm{MNF}$ is probably functioning as an important source area for producing forest songbirds, particularly those of special concern: Neotropical migrants, forest 
interior species, and PIF indicator species. This is a valuable resource that should be maintained.

2. In general, mixed mesophytic forests have the greatest value for species of concern, such as neotropical migrants and those on the partners in Flight list. In any reserve design, therefore, mixed mesophytic forest should be well-represented. Put another way, loss or alteration of this forest type will have greater consequences on overall abundance and diversity than loss of the other forest types.

3. Other forest types, however, should be considered for individual species' needs. For example, dry oaks show relatively low abundance and species richness, but of the four forest types, this is the only type providing meaningful amounts of habitat for worm-eating warbler, a PIF species of concern.

4. The importance of the transect scale in explaining bird diversity indicates the range of existing habitats should be maintained across the MNF landscape.

Disproportionately favoring one forest type or plant association in these activities should be avoided.

5. Local (forest-stand level) considerations are less important than a landscape perspective in documenting and mitigating the effects of proposed land-altering activities.

Finally, this study represents one of the few songbird studies to date with nested, welldefined multiple scales across the landscape, and points to the clear need for standardization in the use of multiple scales and the scope of "landscapes." For example, Villard et al. (1999) defined areas of $6.25 \mathrm{~km} 2$ as landscapes - and nearly all of these were adjacent to 
each other. Blake et al. (1994) used the terms "local" and "regional" to imply different scales, when they were really comparing two broad landscapes, one in northern Michigan and one in Wisconsin. Gutzwiller and Anderson (1987) used three scales-nest tree, the area around the nest tree, and the forest fragments (ranging from 0.1 to $32.3 \mathrm{ha}$ ) as the third scale. The latter arguably represents multiple scales in itself.

Setting standard sizes for landscapes and multiple scales would therefore be a worthy endeavor for professional societies, such as the Society for Conservation Biology or the International Association for Landscape Ecology. Panels of experts could set up the standards for each broad ecological region. Such standards would make comparisons possible, reduce confusion, and avoid misinterpretations, such as concluding a broad landscape-scale effect, when in fact the scope of results was limited to the variation across a single landscape. 


\section{Literature Cited}

Askins, R.A., J.F. Lynch, and R. Greenberg. 1990. Population declines in migratory birds in eastern North America. pp. 1-57 in Power, D.M. (ed.) Current ornithology: volume 7 New York: Plenum Press.

Beers, T.W., P.E. Dress, and L.C. Wensel. 1966. Aspect transformation in site productivity research. J.For. 64:691-692.

Bender, J.R. 1999. Identifying structural differences in mixed mesophyutic and northern hardwood forests on the Monongahela National Forest using remote sensing data. M.S. thesis, Dept. of Geology and Geography, West Virginia Univ., Morgantown.

Blake, J.G., J.M. Hanowski, G.J. Niemi, and P.T. Collins. 1994. Annual variation in bird populations of mixed conifer-northern hardwood forests. Condor 96:381-399.

Brittingham, M. and S. Temple. 1983. Have cowbirds caused forest songbirds to decline? BioScience 33:31-35.

Buford, E.W., and D.E. Capen. 1999. Abundance and productivity of forest songbirds in a managed, unfragmented landscape in Vermont. J. Wildl. Manage. 63(1):180-188.

Clark University. 1995. Idrisi GIS software user's manual. Cambridge, MA: Clark University.

Dawson, D.K., L.J. Darr, and C.S. Robbins. 1993. Predicting the distribution of breeding forest birds in a fragmented landscape. Trans. 58th N.A. Wildl. \& Natur. Resour. Conf., pp. 35-43.

DeMeo, T. 1998. Terrestrial ecological classification of the Monongahela National Forest, West Virginia. On file at USDA For. Serv., Elkins, WV.

Donovan, T.M., R.H. Lamberson, A. Kimber, F.R. Thompson III, and J. Faaborg. 1995a. Modeling the effects of habitat fragmentation on source and sink demography of neotropical migrant birds. Conserv. Biol. 9(6):1396-1407.

Donovan, T.M., F.R. Thompson III, J. Faaborg, and J.R. Probst. 1995b. Reproductive success of migratory birds in habitat sources and sinks. Conserv. Biol 9:1380-1395.

Freemark, K., and B. Collins. 1992. Landscape ecology of birds breeding in temperate forest fragments. pp. 443-454 in J.M. Hagan III and D.W. Johnston, eds. Ecology and conservation of neotropical migrant landbirds. Washington, DC: Smithsonian Institution Press.

Gutzwiller, K.J., and S.H. Anderson. 1987. Multiscale associations between cavity-nesting birds and features of Wyoming streamside woodlands. Condor 89:534-548. 
James, F.C., and H.H. Shugart, Jr. 1970. A quantitative method of habitat description. Audubon Field Notes 24(6):727-736. Wildl. Res. Unit, 27 pp.

Kachigan, S.K. 1986. Statistical analysis. New York: Radius Press, 589 pp.

Kuchler, A.W. 1964. Map and manual, potential natural vegetation of the coterminous United States. Amer. Geog. Soc. Special Publ. No. 36, 156 pp.

MacArthur, R.H. 1958. Population ecology of some warblers of northeastern coniferous forests. Ecology 39:599-619.

McGarigal, K. 1993. Relationship between landscape structure and avian abundance configurations in the Oregon Coast Range. Dissertation. Oregon State University, Corvallis.

McGarigal, K., and B.J. Marks. 1995. FRAGSTATS: spatial pattern analysis program for quantifying landscape structure. Gen. Tech. Rep. PNW-GTR-351. Portland, OR: USDA For. Serv., Pacific Northwest Research Station, 122 pp.

Meier, A.J., S.B. Bratton, and D.C. Duffy. 1996. Possible ecological mechanisms for loss of vernal herb diversity in logged Eastern deciduous forest. Ecol. Appl. In press.

Oliver, C.D., and B.C. Larson. 1996. Forest stand dynamics. New York: John Wiley and Sons, $520 \mathrm{pp}$.

Partners in Flight. 1998. Newsletter of the West Virginia Partners in Flight Working Group. Elkins, WV, Spring 1998.

Peterjohn, B.G., and J.R. Sauer. 1994. Population trends of woodland birds from the North American breeding bird survey. Wildl. Soc. Bull. 22:155-164.

Petersen, R.G. 1985. Design and analysis of experiments. New York: Marcel Dekker, 429 pp.

Ralph, C.J., G.R. Geupel, P. Pyle, T.E. Martin, and D.E. DeSante. 1993. Handbook of field methods for monitoring landbirds. Gen. Tech. Rep. PSW-GTR-144. Albany,CA: Pacific Southwest Res. Sta., USDA For. Serv.

Riitters, K.H., R.V. O'Neill, C.T. Hunsaker, J.D. Wickham, D.H. Yankee, S.P. Timmins, K.B. Jones, and B.L. Jackson. 1995. A factor analysis of landscape pattern and structure metrics. Landsc. Ecol. 10(1):23-39. 
Robinson, S.K. 1992. Population dynamics of breeding neotropical migrants in a fragmented Illinois landscape. in J.M. Hagan III and D.W. Johnston, eds. Ecology and conservation of neotropical migrant landbirds. Washington, DC: Smithsonian Institution Press.

Robinson, S.K., F.R. Thompson III, T.M. Donovan, D.R. Whitehead, and J. Faaborg. 1995a. Regional effects of forest fragmentation on the nesting success of migratory birds. Science 267: 1987-1990.

Rosenberg, K.V., and J.V. Wells. 1995. Importance of geographic areas to neotropical migrant birds in the Northeast. Hadley, MA: USDI Fish and Wildl. Serv. Report, 120 pp.

SAS Institute. 1988. SAS/STAT user's guide. Cary, NC: Sas Institute, 1028 pp.

Temple, S.A., and J.R. Cary. 1988. Modeling dynamics of habitat-interior bird populations in fragmented landscapes. Conserv. Biol. 2(4):340-347.

Thompson, F.R., III, W.D. Dijak, T.G. Kulowiec, and D.A. Hamilton. 1992. Breeding bird populations in Missouri Ozark Forests with and without clearcutting. J. Wildl. Manage. 56:23-30.

Trimble. 1995. Trimble Explorer user's guide. Trimble Corp., Sunnyvale, CA.

Villard, M., M.K. Trzcinski, and G. Merriam. 1999. Fragmentation effects on forest birds: Relative influence of woodland cover and configuration on landscape occupancy. Conserv. Biol. 13(4):774-783.

Welsh, C.J.E., and W.M. Healy. 1993. Effect of even-aged timber management on bird species diversity and composition in northern hardwoods of New Hampshire. Wildl. Soc. Bull. 21:143-154.

Whittaker, R.H. 1960. Vegetation of the Siskiyou Mountains, Oregon and California. Ecol. Monogr. 30:279-338.

Withers, M.A., and V. Meentemeyer. 1999. Concepts of scale in landscape ecology. Pp. 205251 in J.M. Klopatek and R.H. Gardner, eds. Landscape ecological analysis: Issues and applications. New York: Springer-Verlag.

Zar. 1984. Biostatistical analysis. Englewood Cliffs, NJ: Prentice-Hall. 
Table 3-1. Analysis of variance (ANOVA), entire point count set, with bird abundance and species richness as response variables in separate ANOVAs. Monongahela National Forest, 1996-1997.

\begin{tabular}{|c|c|c|c|c|c|}
\hline Source & DF & $\begin{array}{l}\text { Type III } \\
\text { SS }\end{array}$ & Mean Square & $\mathrm{F}$ & $\operatorname{Pr}>\mathrm{F}$ \\
\hline \multicolumn{6}{|l|}{ Bird Abundance } \\
\hline Forest Type & 3 & 1257.3 & 419.1 & 3.34 & 0.08 \\
\hline Block (Forest Type) & 8 & 1003.6 & 125.5 & & \\
\hline Riparian & 1 & 205.1 & 205.1 & 6.64 & 0.01 \\
\hline Riparian*Forest Type & 3 & 28.4 & 9.5 & 0.31 & 0.82 \\
\hline Transect (Block*Riparian*ForType) & 32 & 987.8 & 30.9 & 3.66 & 0.0001 \\
\hline Point (Block*Transect*Rip*For Type) & 503 & 4247.2 & 8.4 & & \\
\hline Year & 1 & 671.6 & 671.6 & & 0.0001 \\
\hline Year*Forest Type & 3 & 76.8 & 25.6 & & \\
\hline Year*Riparian & 1 & 102.0 & 102.0 & & \\
\hline Year*Riparian*Forest Type & 3 & 13.0 & 4.3 & & \\
\hline \multicolumn{6}{|l|}{ Bird Species Richness } \\
\hline Forest Type & 3 & 657.4 & 219.1 & 3.42 & 0.07 \\
\hline Block (Forest Type) & 8 & 512.0 & 64.0 & & \\
\hline Riparian & 1 & 103.9 & 103.9 & 5.96 & 0.02 \\
\hline Riparian*Forest Type & 3 & 24.2 & 8.1 & 0.46 & 0.71 \\
\hline Transect (Block*Riparian*ForType) & 32 & 558.0 & 17.4 & 3.55 & 0.0001 \\
\hline Point (Block*Transect*Rip*For Type) & 503 & 2471.0 & 4.9 & & \\
\hline Year & 1 & 588.2 & 588.2 & & 0.0001 \\
\hline Year*Forest Type & 3 & 36.5 & 12.2 & & \\
\hline Year*Riparian & 1 & 55.8 & 55.8 & & \\
\hline Year*Riparian*Forest Type & 3 & 11.2 & 3.7 & & \\
\hline
\end{tabular}


Table 3-2. Bird abundance and species richness by bird group among the four major forest types of the Monongahela National Forest, 1996-1997. Values followed by the same letter for a response variable within a row are not significantly different at $p=0.05$ (Duncan's multiple range test). $n=n o$. of points $X$ two years. Note species richness does not apply when individual species are considered; hence these columns are blank. PIF=Partners in Flight.

\begin{tabular}{|c|c|c|c|c|c|c|c|c|}
\hline \multirow[t]{2}{*}{ Bird Group } & \multicolumn{2}{|c|}{$\begin{array}{l}\text { Mixed Mesophytic } \\
(\mathrm{n}=272)\end{array}$} & \multicolumn{2}{|c|}{$\begin{array}{l}\text { Northern } \\
\text { Hardwoods }(\mathrm{n}=265)\end{array}$} & \multicolumn{2}{|c|}{$\begin{array}{l}\text { Red Spruce } \\
(\mathrm{n}=276)\end{array}$} & \multicolumn{2}{|c|}{$\begin{array}{l}\text { Dry Oaks } \\
(\mathrm{n}=266)\end{array}$} \\
\hline & Richness & Abundance & Richness & Abundance & Richness & Abundance & Richness & Abundance \\
\hline Overall & 6.89A & $8.77 \mathrm{~A}$ & 4.56B & 5.47B & $5.59 \mathrm{AB}$ & 6.67AB & $5.17 \mathrm{~B}$ & 6.06B \\
\hline \multicolumn{9}{|l|}{ Nesting Guild } \\
\hline Ground & $1.34 \mathrm{~B}$ & $1.55 \mathrm{~B}$ & $1.27 \mathrm{~B}$ & $1.53 \mathrm{~B}$ & $1.34 \mathrm{~B}$ & $1.65 \mathrm{~B}$ & $1.74 \mathrm{~A}$ & $2.10 \mathrm{~A}$ \\
\hline High Canopy & $1.70 \mathrm{AB}$ & $2.04 \mathrm{AB}$ & $1.54 \mathrm{~B}$ & $1.80 \mathrm{~B}$ & $1.95 \mathrm{~A}$ & $2.38 \mathrm{~A}$ & $1.58 \mathrm{~B}$ & $1.78 \mathrm{~B}$ \\
\hline Low Canopy & $2.64 \mathrm{~A}$ & $3.74 \mathrm{~A}$ & $1.72 \mathrm{~B}$ & $2.19 \mathrm{~B}$ & $1.70 \mathrm{~A}$ & $2.04 \mathrm{~B}$ & $1.87 \mathrm{~B}$ & $2.24 \mathrm{~B}$ \\
\hline Shrub & $1.83 \mathrm{~A}$ & $2.29 \mathrm{~A}$ & $1.30 \mathrm{BC}$ & $1.50 \mathrm{~B}$ & $1.20 \mathrm{C}$ & $1.40 \mathrm{~B}$ & $1.43 \mathrm{~B}$ & 1.62B \\
\hline Cavity & $1.31 \mathrm{~A}$ & $1.43 \mathrm{~A}$ & $1.16 \mathrm{~A}$ & $1.34 \mathrm{~A}$ & $1.32 \mathrm{~A}$ & $1.48 \mathrm{~A}$ & $1.33 \mathrm{~A}$ & $1.66 \mathrm{~A}$ \\
\hline \multicolumn{9}{|l|}{ Migratory Guild } \\
\hline Short & $1.24 \mathrm{BC}$ & 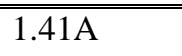 & $1.35 \mathrm{AB}$ & "1.58A & $1.46 \mathrm{~A}$ & 1.69A & $1.13 \mathrm{C}$ & $1.38 \mathrm{~A}$ \\
\hline Neotropical & $5.69 \mathrm{~A}$ & $7.43 \mathrm{~A}$ & $3.49 \mathrm{~B}$ & $4.25 \mathrm{~B}$ & $4.09 \mathrm{~B}$ & $4.59 \mathrm{~B}$ & $3.74 \mathrm{~B}$ & $4.77 \mathrm{~B}$ \\
\hline Resident & $1.42 \mathrm{~A}$ & $1.55 \mathrm{~A}$ & $1.30 \mathrm{~A}$ & $1.47 \mathrm{~A}$ & $1.34 \mathrm{~A}$ & $1.45 \mathrm{~A}$ & $1.42 \mathrm{~A}$ & $1.79 \mathrm{~A}$ \\
\hline \multicolumn{9}{|l|}{ Foraging Guild } \\
\hline Ground & $1.75 \mathrm{~A}$ & $2.10 \mathrm{~A}$ & $1.57 \mathrm{~A}$ & $1.87 \mathrm{~A}$ & $1.73 \mathrm{~A}$ & $2.05 \mathrm{~A}$ & $1.62 \mathrm{~A}$ & $1.93 \mathrm{~A}$ \\
\hline Foliage & $1.07 \mathrm{~A}$ & $1.29 \mathrm{~A}$ & $1.00 \mathrm{~A}$ & $1.15 \mathrm{~A}$ & $1.00 \mathrm{~A}$ & $1.08 \mathrm{~A}$ & $1.04 \mathrm{~A}$ & $1.25 \mathrm{~A}$ \\
\hline Bark & $1.16 \mathrm{~A}$ & $1.29 \mathrm{~A}$ & $1.09 \mathrm{~A}$ & $1.21 \mathrm{~A}$ & $1.15 \mathrm{~A}$ & $1.36 \mathrm{~A}$ & $1.18 \mathrm{~A}$ & $1.42 \mathrm{~A}$ \\
\hline Mix & $3.15 \mathrm{~A}$ & $4.25 \mathrm{~A}$ & $1.90 \mathrm{C}$ & $2.41 \mathrm{~B}$ & $1.88 \mathrm{C}$ & $2.24 \mathrm{~B}$ & $2.52 \mathrm{~B}$ & $3.01 \mathrm{~B}$ \\
\hline \multicolumn{9}{|l|}{ Habitat Guild } \\
\hline Edge & $1.59 \mathrm{~A}$ & $2.00 \mathrm{~A}$ & $1.24 \mathrm{~B}$ & $1.64 \mathrm{AB}$ & 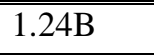 & $1.33 \mathrm{~B}$ & $1.16 \mathrm{~B}$ & $1.44 \mathrm{~B}$ \\
\hline Interior/Edge & $2.26 \mathrm{~A}$ & $3.15 \mathrm{~A}$ & $1.59 \mathrm{~B}$ & $2.06 \mathrm{~B}$ & $1.70 \mathrm{AB}$ & $2.07 \mathrm{~B}$ & $2.10 \mathrm{AB}$ & $2.49 \mathrm{AB}$ \\
\hline Forest Interior & $4.04 \mathrm{~A}$ & $4.91 \mathrm{~A}$ & $3.05 \mathrm{~B}$ & $3.51 \mathrm{~B}$ & $3.69 \mathrm{AB}$ & 4.40AB & $3.05 \mathrm{~B}$ & $3.57 \mathrm{~B}$ \\
\hline \multicolumn{9}{|l|}{$\begin{array}{l}\text { PIF Species of } \\
\text { Interest }\end{array}$} \\
\hline Cerulean warbler & & $0.132 \mathrm{~A}$ & & 0.004B & & $0.054 \mathrm{~B}$ & & 0.049B \\
\hline $\begin{array}{l}\text { Worm-eating } \\
\text { warbler }\end{array}$ & & $0.074 \mathrm{~B}$ & & $0.008 \mathrm{~B}$ & & $0.015 \mathrm{~B}$ & & $0.504 \mathrm{~A}$ \\
\hline Red-eyed vireo & & $1.412 \mathrm{~A}$ & & $0.842 \mathrm{~B}$ & & $0.015 \mathrm{~B}$ & & $0.504 \mathrm{~A}$ \\
\hline Wood thrush & & $0.379 \mathrm{~A}$ & & $0.038 \mathrm{~B}$ & & $0.054 \mathrm{~B}$ & & $0.165 \mathrm{~B}$ \\
\hline Hooded warbler & & $0.279 \mathrm{~A}$ & & $0.053 \mathrm{~A}$ & & $0.022 \mathrm{~A}$ & & $0.045 \mathrm{~A}$ \\
\hline $\begin{array}{l}\text { Acadian } \\
\text { flycatcher }\end{array}$ & & $0.500 \mathrm{~A}$ & & $0.030 \mathrm{C}$ & & $0.018 \mathrm{C}$ & & $0.323 \mathrm{~B}$ \\
\hline $\begin{array}{l}\text { Louisiana } \\
\text { waterthrush }\end{array}$ & & $0.066 \mathrm{~A}$ & & $0.023 \mathrm{AB}$ & & $0.011 \mathrm{~B}$ & & $0.038 \mathrm{AB}$ \\
\hline Scarlet tanager & & $0.489 \mathrm{~A}$ & & $0.113 \mathrm{~B}$ & & $0.051 \mathrm{~B}$ & & $0.376 \mathrm{~A}$ \\
\hline $\begin{array}{l}\text { Eastern wood } \\
\text { peewee }\end{array}$ & & $0.147 \mathrm{~A}$ & & $0.008 \mathrm{~B}$ & & $0.018 \mathrm{~B}$ & & $0.177 \mathrm{~A}$ \\
\hline
\end{tabular}


Table 3-3. Results of regression models to explain variation in bird abundance for all birds and selected guilds in each forest type, comparison of transect and point scales. 1996-1997 point count data, Monongahela National Forest. A minus sign indicates the variable was negatively associated with abundance of that species.

\begin{tabular}{|c|c|c|c|c|c|c|c|}
\hline \multicolumn{4}{|c|}{ Mixed mesophytic Transects } & \multicolumn{4}{|c|}{ Mixed mesophytic Points } \\
\hline Species & Variable & $\begin{array}{l}\text { Part. } \\
\text { r2 }\end{array}$ & $\mathrm{p}$ & Species & Variable & $\begin{array}{l}\text { Partial } \\
\text { r2 }\end{array}$ & $\mathrm{p}$ \\
\hline All birds & - -CAN2 $^{\mathrm{a}}$ & 0.49 & 0.01 & All birds & -ELEV & 0.008 & 0.0002 \\
\hline Neo. migrants & -CAN2 & 0.44 & 0.02 & Neo. migrants & -ELEV & 0.006 & 0.003 \\
\hline Residents & None & & & Residents & RHMA & 0.13 & 0.0001 \\
\hline Short-distance & DTW & 0.32 & 0.06 & Short-distance & -CAN5 & 0.07 & 0.005 \\
\hline \multirow[t]{2}{*}{ migrants } & & & & migrants & RHMA & 0.05 & 0.01 \\
\hline & & & & & -ASPECT & 0.02 & 0.09 \\
\hline \multirow[t]{3}{*}{ Edge Species } & -CAN2 & 0.39 & $\mathbf{0 . 0 3}$ & Edge Species & -CAN5 & 0.04 & 0.01 \\
\hline & DTW & $\mathbf{0 . 3 0}$ & $\mathbf{0 . 0 2}$ & & -ASPEC & $\mathbf{0 . 0 2}$ & 0.09 \\
\hline & & & & & STANDH & 0.02 & 0.09 \\
\hline For. Interior & SDIALL & $\mathbf{0 . 3 7}$ & $\mathbf{0 . 0 3}$ & For. Interior & -ELEV & 0.009 & 0.002 \\
\hline Species & ELEV & 0.17 & 0.07 & Species & & & \\
\hline Interior-Edge & -CAN2 & 0.51 & 0.01 & Interior-Edge & -ELEV & 0.006 & 0.07 \\
\hline Species & CAN1 & $\mathbf{0 . 1 7}$ & 0.06 & Species & -CAN5 & 0.005 & $\mathbf{0 . 0 8}$ \\
\hline \multicolumn{4}{|c|}{ Northern Hardwood Transects } & \multicolumn{4}{|c|}{$\begin{array}{l}\text { Northern Hardwood Points } \\
\end{array}$} \\
\hline Species & Variable & Part. r2 & $\mathrm{p}$ & Species & Variable & Part. r2 & $\mathrm{p}$ \\
\hline \multirow[t]{4}{*}{ All birds } & -RHMA & 0.48 & 0.01 & All birds & -CAN1 & 0.005 & 0.02 \\
\hline & CAN4 & 0.19 & 0.05 & & DTW & 0.004 & 0.05 \\
\hline & -CAN3 & 0.09 & 0.07 & & & & \\
\hline & ASPECT & 0.06 & $\mathbf{0 . 0 7}$ & & & & \\
\hline Neotropical & -OSCON & 0.54 & 0.01 & Neotropical & -CAN1 & -0.01 & 0.004 \\
\hline \multirow[t]{2}{*}{ migrants } & CAN2 & 0.16 & 0.06 & migrants & DTW & 0.01 & 0.004 \\
\hline & & & & & -SUMCON & -0.01 & 0.02 \\
\hline \multirow[t]{4}{*}{ Residents } & -CAN6 & 0.26 & 0.02 & Residents & -ASPECTT & 0.06 & 0.02 \\
\hline & & & & & RHMA & 0.03 & 0.08 \\
\hline & & & & & CAN6 & 0.03 & 0.09 \\
\hline & & & & & DTW & 0.03 & 0.06 \\
\hline Short-distance & -CAN6 & 0.24 & 0.10 & Short-distance & -ELEV & 0.05 & 0.09 \\
\hline migrants & & & & migrants & -CAN6 & 0.04 & 0.03 \\
\hline Edge Species & -SDI2 & $\mathbf{0 . 3 3}$ & 0.06 & Edge Species & SUMCON & 0.09 & 0.02 \\
\hline For. Interior & ELEV & (0.39 & 0.02 & For. Interior & -SUMCON & 0.005 & 0.08 \\
\hline \multirow[t]{2}{*}{ Species } & STANDH & 0.25 & 0.03 & Species & $D T W$ & 0.005 & 0.07 \\
\hline & -SUMCO & 0.12 & 0.08 & & OSCON & 0.005 & 0.09 \\
\hline Interior-Edge & -RHMA & 0.42 & 0.02 & Interior-Edge & -CAN2 & 0.01 & 0.05 \\
\hline Species & -SUMCO & 0.17 & 0.08 & Species & & & \\
\hline
\end{tabular}


Table 3-3. Results of regression models to explain variation in bird abundance for all birds and selected guilds in each forest type, comparison of transect and point scales. 1996-1997 point count data, Monongahela National Forest. A minus sign indicates a variable negatively associated with abundance of that species.

\begin{tabular}{|c|c|c|c|c|c|c|c|}
\hline \multicolumn{4}{|c|}{ Red Spruce Transects } & \multicolumn{4}{|l|}{ Red Spruce Points } \\
\hline Species & Variable & Part. r2 & $\mathrm{p}$ & Species & Variable & $\begin{array}{l}\text { Partial } \\
\text { r2 }\end{array}$ & $\mathrm{p}$ \\
\hline \multirow[t]{2}{*}{ All birds } & "DTW & 0.44 & 0.02 & All birds & None & & \\
\hline & STANDH & 0.21 & 0.05 & & & & \\
\hline Neotropical & DTW & 0.42 & $\overline{\mathbf{0 . 0 2}}$ & Neotropical & DTW & 0.003 & 0.09 \\
\hline \multirow[t]{4}{*}{ migrants } & STANDH & 0.31 & 0.01 & migrants & & & \\
\hline & -OSCON & 0.22 & 0.01 & & & & \\
\hline & -ASPECT & 0.02 & 0.09 & & & & \\
\hline & SDIALL & 0.01 & 0.07 & & & & \\
\hline Residents & None & & & Residents & None & & \\
\hline Short-distance & -SDIALL & 0.29 & 0.07 & Short-distance & -STANDHT & 0.02 & 0.01 \\
\hline migrants & & & & migrants & & & \\
\hline Edge Species & None & & & Edge Species & None & & \\
\hline For. Interior & DTW & 0.40 & 0.03 & For. Interior & None & & \\
\hline \multirow[t]{2}{*}{ Species } & STANDH & $\mathbf{0 . 3 1}$ & 0.01 & Species & & & \\
\hline & CAN1 & $\mathbf{0 . 1 3}$ & 0.03 & & & & \\
\hline Interior-Edge & DTW & 0.51 & $\overline{\mathbf{0 . 0 1}}$ & Interior-Edge & DTW & 0.02 & 0.01 \\
\hline \multirow[t]{2}{*}{ Species } & CAN6 & 0.16 & 0.04 & Species & -ASPECT & 0.009 & 0.07 \\
\hline & SDIALL & 0.16 & 0.01 & & -CAN1 & 0.11 & 0.07 \\
\hline \multicolumn{4}{|c|}{ Dry Oak Transects } & \multicolumn{4}{|l|}{ Dry Oak Points } \\
\hline Species & Variable & Part. r2 & $\mathrm{p}$ & Species & Variable & Part. r2 & $\mathrm{p}$ \\
\hline \multirow[t]{2}{*}{ All birds } & -USCON & 0.42 & 0.02 & All birds & "None & & \\
\hline & -SDIALL & 0.19 & 0.07 & & & & \\
\hline Neotropical & -CAN6 & 0.41 & $\overline{0.03}$ & Neotropical & -CAN5 & 0.004 & 0.05 \\
\hline migrants & -DTW & 0.11 & 0.06 & migrants & & & \\
\hline \multirow[t]{2}{*}{ Residents } & None & & & Residents & SUMCON & 0.02 & 0.09 \\
\hline & & & & & -ASPECT & 0.02 & 0.07 \\
\hline Short-dis. migr. & None & & & Short-dis. migr & None & & \\
\hline \multirow[t]{2}{*}{ Edge Species } & ELEV & 0.23 & 0.08 & Edge Species & None & & \\
\hline & SDIALL & 0.22 & 0.05 & & & & \\
\hline For. Interior & -CAN6 & 0.39 & 0.03 & For. Interior & -CAN5 & 0.007 & 0.04 \\
\hline \multirow[t]{2}{*}{ Species } & & & & Species & -CAN1 & 0.006 & 0.05 \\
\hline & & & & & -ELEV & 0.007 & 0.04 \\
\hline Interior-Edge & -SUMCO & 0.54 & $\overline{0.01}$ & Interior-Edge & SUMCO & 0.01 & 0.02 \\
\hline \multirow[t]{2}{*}{ Species } & -CAN6 & 0.19 & 0.03 & Species & CAN1 & 0.01 & 0.02 \\
\hline & OSCON & 0.17 & 0.01 & & -CAN4 & 0.007 & 0.09 \\
\hline
\end{tabular}

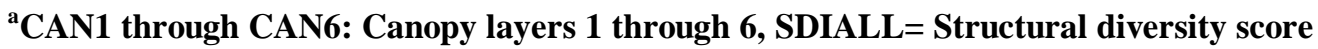
incorporating all six layers, DTW=Distance to water, RHMA=Rhododendron cover, ELEV=Elevation, SUMCON=Sum of overstory and understory conifer covers, OSCON= Overstory conifer cover, USCON=Understory conifer cover, ASPECT=Aspect, and STANDH=Stand height. 
Table 3-4. Results of regression models to explain variation in bird abundance for ten most abundant species in each forest type, comparison of transect and point scales. 1996-1997 point count data, Monongahela National Forest. A minus sign indicates the variable was negatively associated with abundance of that species.

\begin{tabular}{|c|c|c|c|c|c|c|c|}
\hline \multicolumn{4}{|c|}{ Mixed mesophytic Transects } & \multicolumn{4}{|c|}{ Mixed mesophytic Points } \\
\hline Species & Variable & $\begin{array}{l}\text { Partial } \\
\text { r2 }\end{array}$ & $\mathrm{p}$ & Species & Variable & $\begin{array}{l}\text { Partial } \\
\text { r2 }\end{array}$ & $\mathrm{p}$ \\
\hline \multirow[t]{4}{*}{$\overline{A C F L}$} & $-\mathrm{DTW}^{\mathrm{a}}$ & 0.28 & 0.08 & ACFL & SUMCON & 0.04 & 0.04 \\
\hline & -STANDHT & 0.17 & 0.14 & & CAN5 & 0.03 & 0.10 \\
\hline & CAN6 & 0.22 & 0.05 & & -DTW & 0.04 & 0.03 \\
\hline & -CAN1 & 0.17 & 0.03 & & & & \\
\hline \multirow[t]{4}{*}{ AMRE } & -ASPECTT & 0.25 & 0.09 & AMRE & SLOPE & 0.09 & 0.001 \\
\hline & -CAN6 & 0.38 & 0.01 & & -CAN6 & 0.03 & 0.047 \\
\hline & -CAN1 & 0.14 & 0.06 & & -ELEV & 0.08 & 0.003 \\
\hline & & & & & CAN2 & 0.03 & 0.05 \\
\hline \multirow[t]{2}{*}{ BAWW } & CAN6 & -0.29 & 0.09 & BAWW & None & & \\
\hline & SLOPE & 0.23 & 0.09 & & & & \\
\hline \multirow[t]{5}{*}{ BTNW } & STANDHT & 0.58 & 0.004 & BTNW & -CAN3 & 0.03 & 0.07 \\
\hline & SUMCON & 0.22 & 0.01 & & SLOPE & 0.02 & 0.09 \\
\hline & -CAN2 & 0.09 & 0.003 & & SUMCON & 0.02 & 0.14 \\
\hline & CAN1 & 0.04 & 0.002 & & & & \\
\hline & CAN6 & 0.03 & 0.04 & & & & \\
\hline \multirow{2}{*}{$R B G R$} & -OSCON & 0.26 & 0.11 & RBGR & CAN3 & 0.06 & 0.04 \\
\hline & -DTW & 0.36 & $\mathbf{0 . 0 3}$ & & & & \\
\hline \multirow[t]{4}{*}{$R E V I$} & -ASPECTT & 0.28 & 0.07 & REVI & DTW & 0.02 & 0.07 \\
\hline & -RHMA & 0.37 & 0.01 & & -ELEV & 0.01 & 0.07 \\
\hline & -CAN1 & 0.13 & 0.06 & & -CAN1 & 0.01 & 0.11 \\
\hline & & & & & -RHMA & 0.02 & 0.06 \\
\hline \multirow[t]{3}{*}{ SCTA } & ASPECTT & -0.28 & 0.08 & SCTA & None & & \\
\hline & RHMA & -0.37 & 0.01 & & & & \\
\hline & CAN1 & -0.13 & 0.06 & & & & \\
\hline SOVI & None & & & SOVI & None & & \\
\hline \multirow[t]{4}{*}{ VEER } & -SDIALL & 0.61 & 0.007 & VEER & CAN5 & 0.05 & 0.08 \\
\hline & -DTW & 0.12 & 0.147 & & -ELEV & 0.09 & 0.01 \\
\hline & STANDHT & 0.09 & 0.05 & & & & \\
\hline & -CAN2 & 0.10 & 0.11 & & & & \\
\hline \multirow[t]{2}{*}{ WOTH } & SUMCON & 0.48 & 0.01 & WOTH & SDIALL & 0.05 & 0.04 \\
\hline & & & & & STANDHT & 0.04 & 0.09 \\
\hline
\end{tabular}


Table 3-4 (Continued). Results of regression models to explain variation in bird abundance for ten most abundant species in each forest type, comparison of transect and point scales. 1996-1997 point count data, Monongahela National Forest. A minus sign indicates the variable was negatively associated with abundance of that species.

\begin{tabular}{|c|c|c|c|c|c|c|c|}
\hline \multicolumn{4}{|c|}{ Northern Hardwood Transects } & \multicolumn{4}{|c|}{ Northern Hardwood Points } \\
\hline Species & Variable & $\begin{array}{l}\text { Partial } \\
\text { r2 }\end{array}$ & $\mathrm{p}$ & Species & Variable & $\begin{array}{l}\text { Partial } \\
\text { r2 }\end{array}$ & $\mathrm{p}$ \\
\hline \multirow[t]{7}{*}{$\mathrm{BCCH}$} & DTW & 0.41 & 0.03 & $\mathrm{BCCH}$ & SUMCON & 0.11 & 0.04 \\
\hline & & & & & STANDHT & 0.09 & 0.07 \\
\hline & & & & & CAN2 & 0.06 & 0.06 \\
\hline & & & & & CAN6 & 0.08 & 0.09 \\
\hline & & & & & DTW & 0.07 & 0.10 \\
\hline & & & & & RHMA & 0.07 & 0.10 \\
\hline & & & & & -ASPECTT & 0.11 & 0.03 \\
\hline \multirow[t]{2}{*}{ BLBW } & -SDIALL & 0.38 & 0.04 & BLBW & OSCON & 0.07 & 0.05 \\
\hline & & & & & -SLOPE & 0.04 & 0.10 \\
\hline \multirow{2}{*}{ BTBW } & -ELEV & 0.52 & 0.01 & BTBW & -ELEV & 0.04 & $\overline{0.04}$ \\
\hline & -CAN6 & 0.23 & $\mathbf{0 . 0 3}$ & & RHMA & 0.03 & 0.14 \\
\hline \multirow[t]{2}{*}{ BTNW } & ASPECTT & 0.38 & 0.03 & BTNW & -SUMCON & 0.06 & 0.006 \\
\hline & & & & & DTW & 0.02 & 0.05 \\
\hline \multirow[t]{5}{*}{ DEJU } & -DTW & 0.39 & $\mathbf{0 . 0 3}$ & DEJU & -CAN3 & 0.05 & 0.05 \\
\hline & & & & & -DTW & 0.03 & 0.03 \\
\hline & & & & & -SDIALL & 0.05 & 0.03 \\
\hline & & & & & -CAN4 & 0.06 & 0.03 \\
\hline & & & & & SLOPE & 0.04 & -0.07 \\
\hline \multirow[t]{3}{*}{$M A W A$} & None & & & MAWA & -CAN4 & 0.09 & 0.01 \\
\hline & & & & & STANDHT & 0.05 & 0.07 \\
\hline & & & & & -SDIALL & 0.06 & 0.02 \\
\hline \multirow[t]{10}{*}{$R E V I$} & -SUMCON & 0.53 & 0.008 & REVI & -SUMCO & 0.05 & 0.007 \\
\hline & -RHMA & 0.11 & 0.13 & & DTW & 0.02 & 0.02 \\
\hline & -ASPECTT & 0.11 & 0.09 & & -CAN2 & 0.03 & 0.02 \\
\hline & OSCON & 0.10 & 0.06 & & -CAN6 & 0.01 & 0.14 \\
\hline & DTW & 0.05 & 0.12 & & STANDHT & 0.02 & 0.11 \\
\hline & & & & & CAN4 & 0.04 & 0.009 \\
\hline & & & & & -SDIALL & 0.03 & 0.03 \\
\hline & & & & & -CAN1 & 0.03 & 0.05 \\
\hline & & & & & -OSCON & 0.02 & 0.07 \\
\hline & & & & & -ELEV & 0.02 & 0.07 \\
\hline
\end{tabular}


Table 3-4(Continued). Results of regression models to explain variation in bird abundance for ten most abundant species in each forest type, comparison of transect and point scales. 1996-1997 point count data, Monongahela National Forest. A minus sign indicates the variable was negatively associated with abundance of that species.

\begin{tabular}{|c|c|c|c|c|c|c|c|}
\hline \multicolumn{4}{|c|}{ Northern Hardwood Transects } & \multicolumn{4}{|c|}{ Northern Hardwood Points } \\
\hline Species & Variables & $\begin{array}{l}\text { Partial } \\
\text { r2 }\end{array}$ & $\mathrm{p}$ & Species & Variables & $\begin{array}{l}\text { Partial } \\
\text { r2 }\end{array}$ & $\mathrm{p}$ \\
\hline \multirow[t]{5}{*}{ SOVI } & -CAN1 & 0.60 & 0.005 & SOVI & DTW & 0.04 & 0.10 \\
\hline & & & & & -CAN5 & 0.08 & 0.02 \\
\hline & & & & & STANDT & 0.12 & 0.003 \\
\hline & & & & & -CAN6 & 0.08 & 0.008 \\
\hline & & & & & -SDIALL & 0.06 & 0.05 \\
\hline VEER & STANDHT & 0.29 & 0.07 & VEER & None & & \\
\hline \multirow[t]{5}{*}{ WIWR } & None & & & WIWR & -CAN1 & 0.07 & 0.07 \\
\hline & & & & & -ELEV & 0.06 & 0.09 \\
\hline & & & & & -CAN6 & 0.05 & 0.13 \\
\hline & & & & & -SUMCON & 0.06 & 0.07 \\
\hline & & & & & OSCON & 0.04 & 0.14 \\
\hline \multicolumn{4}{|c|}{ Red Spruce Transects } & \multicolumn{4}{|c|}{ Red Spruce Points } \\
\hline Species & Variables & $\begin{array}{l}\text { Partial } \\
\text { r2 }\end{array}$ & $\mathrm{p}$ & Species & Variables & $\begin{array}{l}\text { Partial } \\
\text { r2 }\end{array}$ & $\mathrm{p}$ \\
\hline \multirow[t]{3}{*}{ ВCCH } & -CAN1 & 0.32 & 0.05 & $\mathrm{BCCH}$ & ELEV & 0.05 & 0.13 \\
\hline & -RHMA & 0.28 & 0.03 & & & & \\
\hline & DTW & 0.10 & 0.14 & & & & \\
\hline \multirow[t]{3}{*}{ BLBW } & None & & & BLBW & CAN6 & 0.03 & 0.11 \\
\hline & & & & & CAN5 & 0.04 & 0.05 \\
\hline & & & & & CAN4 & 0.06 & 0.03 \\
\hline \multirow[t]{2}{*}{ BTBW } & SLOPE & 0.23 & 0.11 & BTBW & -OSCON & 0.04 & 0.14 \\
\hline & & & & & ASPECTT & 0.03 & 0.15 \\
\hline \multirow[t]{3}{*}{ BTNW } & ELEV & 0.31 & 0.06 & BTNW & SDIALL & 0.02 & 0.10 \\
\hline & & & & & ELEV & 0.01 & 0.14 \\
\hline & & & & & CAN4 & 0.02 & 0.10 \\
\hline \multirow[t]{7}{*}{ DEJU } & -SLOPE & 0.38 & 0.03 & DEJU & STANDHT & 0.03 & 0.03 \\
\hline & & & & & -USCON & 0.03 & 0.04 \\
\hline & & & & & -CAN6 & 0.02 & 0.13 \\
\hline & & & & & -RHMA & 0.02 & 0.11 \\
\hline & & & & & DTW & 0.05 & 0.01 \\
\hline & & & & & -ASPECTT & 0.02 & 0.11 \\
\hline & & & & & -CAN4 & 0.02 & 0.10 \\
\hline
\end{tabular}


Table 3-4 (Continued). Results of regression models to explain variation in bird abundance for ten most abundant species in each forest type, comparison of transect and point scales. 1996-1997 point count data, Monongahela National Forest. A minus sign indicates the variable was negatively associated with abundance of that species.

\begin{tabular}{|c|c|c|c|c|c|c|c|}
\hline Species & Variables & $\begin{array}{l}\text { Partial } \\
\mathrm{r} 2\end{array}$ & $\mathrm{p}$ & Species & Variables & $\begin{array}{l}\text { Partial } \\
\text { r2 }\end{array}$ & $\mathrm{p}$ \\
\hline \multirow[t]{7}{*}{ GCKI } & -SDI2 & 0.39 & 0.03 & GCKI & SDIALL & 0.06 & 0.02 \\
\hline & & & & & -CAN2 & 0.09 & 0.003 \\
\hline & & & & & -STANDHT & 0.02 & 0.12 \\
\hline & & & & & -CAN3 & 0.02 & 0.13 \\
\hline & & & & & USCON & 0.03 & 0.10 \\
\hline & & & & & -CAN1 & 0.05 & 0.04 \\
\hline & & & & & -CAN6 & 0.02 & 0.14 \\
\hline \multirow[t]{5}{*}{ MAWA } & ELEV & 0.27 & 0.08 & MAWA & USCON & 0.03 & 0.03 \\
\hline & & & & & RHMA & 0.07 & 0.001 \\
\hline & & & & & ASPECTT & 0.02 & 0.14 \\
\hline & & & & & -SDIALL & 0.02 & 0.13 \\
\hline & & & & & CAN5 & 0.04 & 0.04 \\
\hline \multirow[t]{3}{*}{ REVI } & -SDI1 & 0.34 & 0.06 & REVI & SUMCON & 0.03 & 0.08 \\
\hline & -ASPECTT & 0.19 & 0.11 & & CAN4 & 0.05 & 0.03 \\
\hline & & & & & -SDIALL & 0.03 & 0.12 \\
\hline \multirow[t]{2}{*}{ SOVI } & -RHMA & 0.45 & 0.02 & SOVI & SLOPE & 0.02 & 0.10 \\
\hline & SLOPE & 0.22 & 0.04 & & & & \\
\hline \multirow[t]{7}{*}{ WIWR } & ELEV & 0.27 & 0.09 & WIWR & CAN5 & 0.06 & 0.01 \\
\hline & & & & & CAN1 & 0.03 & 0.10 \\
\hline & & & & & OSCON & 0.02 & 0.14 \\
\hline & & & & & RHMA & 0.03 & 0.10 \\
\hline & & & & & CAN3 & 0.03 & 0.03 \\
\hline & & & & & CAN4 & 0.03 & 0.11 \\
\hline & & & & & ASPECTT & 0.03 & 0.11 \\
\hline
\end{tabular}


Table 3-4 (Continued). Results of regression models to explain variation in bird abundance for ten most abundant species in each forest type, comparison of transect and point scales. 1996-1997 point count data, Monongahela National Forest.

\begin{tabular}{|c|c|c|c|c|c|c|c|}
\hline \multicolumn{4}{|c|}{ Dry Oak Transects } & \multicolumn{4}{|c|}{ Dry Oak Points } \\
\hline Species & Variables & $\begin{array}{l}\text { Partial } \\
\text { r2 }\end{array}$ & $\mathrm{p}$ & Species & Variables & $\begin{array}{l}\text { Partial } \\
\text { r2 }\end{array}$ & $\mathrm{p}$ \\
\hline \multirow[t]{2}{*}{ ACFL } & None & & & ACFL & SUMCON & 0.06 & 0.04 \\
\hline & & & & & -SLOPE & 0.15 & 0.001 \\
\hline BAWW & ELEV & 0.28 & 0.08 & BAWW & ELEV & 0.06 & 0.02 \\
\hline \multirow[t]{2}{*}{ BGGN } & OSCON & 0.52 & 0.04 & BGGN & CAN2 & 0.19 & 0.01 \\
\hline & & & & & CAN3 & 0.06 & 0.06 \\
\hline \multirow[t]{2}{*}{ BTNW } & STANDHT & 0.71 & 0.001 & BTNW & CAN3 & 0.06 & 0.06 \\
\hline & & & & & CAN1 & 0.06 & 0.06 \\
\hline \multirow[t]{3}{*}{ EAWP } & SDI2 & 0.31 & 0.06 & EAWP & CAN1 & 0.14 & 0.01 \\
\hline & ASPECTT & 0.33 & 0.02 & & -ELEV & 0.05 & 0.14 \\
\hline & DTW & 0.12 & 0.08 & & & & \\
\hline \multirow[t]{3}{*}{ OVEN } & ASPECTT & 0.27 & 0.09 & OVEN & -SDIALL & 0.04 & 0.03 \\
\hline & -SUMCON & 0.22 & 0.08 & & SLOPE & 0.04 & 0.03 \\
\hline & -SDI2 & 0.17 & 0.09 & & & & \\
\hline \multirow[t]{5}{*}{ REVI } & -SDI6 & 0.44 & 0.02 & REVI & USCON & 0.02 & 0.06 \\
\hline & ELEV & 0.27 & 0.02 & & -CAN4 & 0.02 & 0.10 \\
\hline & SLOPE & 0.09 & 0.10 & & RHMA & 0.07 & 0.002 \\
\hline & -STANDHT & 0.06 & 0.12 & & -ELEV & 0.03 & 0.04 \\
\hline & -ASPECTT & 0.06 & 0.09 & & SLOPE & 0.05 & 0.007 \\
\hline SCTA & -SDI6 & 0.21 & 0.13 & SCTA & -ELEV & 0.10 & 0.004 \\
\hline \multirow[t]{5}{*}{ SOVI } & SDI2 & 0.33 & 0.05 & SOVI & -SLOPE & 0.06 & 0.10 \\
\hline & -ELEV & 0.14 & 0.12 & & -USCON & 0.06 & 0.08 \\
\hline & ASPECTT & 0.16 & 0.05 & & -ASPECTT & 0.07 & 0.09 \\
\hline & & & & & -ELEV & 0.17 & 0.003 \\
\hline & & & & & -CAN1 & 0.09 & 0.03 \\
\hline \multirow[t]{3}{*}{ WBNU } & -ELEV & 0.33 & 0.08 & WBNU & CAN6 & 0.09 & 0.10 \\
\hline & -SDI2 & 0.48 & 0.004 & & -ASPECTT & 0.09 & 0.13 \\
\hline & -RHMA & 0.10 & 0.05 & & & & \\
\hline \multirow[t]{5}{*}{ WEWA } & -SDI6 & 0.57 & 0.005 & WEWA & -CAN5 & 0.06 & 0.01 \\
\hline & SDI2 & 0.16 & 0.05 & & STANDHT & 0.02 & 0.15 \\
\hline & & & & & -USCON & 0.03 & 0.09 \\
\hline & & & & & -SDIALL & 0.03 & 0.06 \\
\hline & & & & & CAN1 & 0.03 & 0.07 \\
\hline
\end{tabular}

${ }^{a}$ CAN1 through CAN6: Canopy layers 1 through 6, SDIALL= Structural diversity score incorporating all six layers, DTW=Distance to water, RHMA=Rhododendron cover, ELEV=Elevation, SUMCON=Sum of overstory and understory conifer covers, $O S C O N=$ Overstory conifer cover, USCON=Understory conifer cover, ASPECT=Aspect, and STANDH=Stand height. 


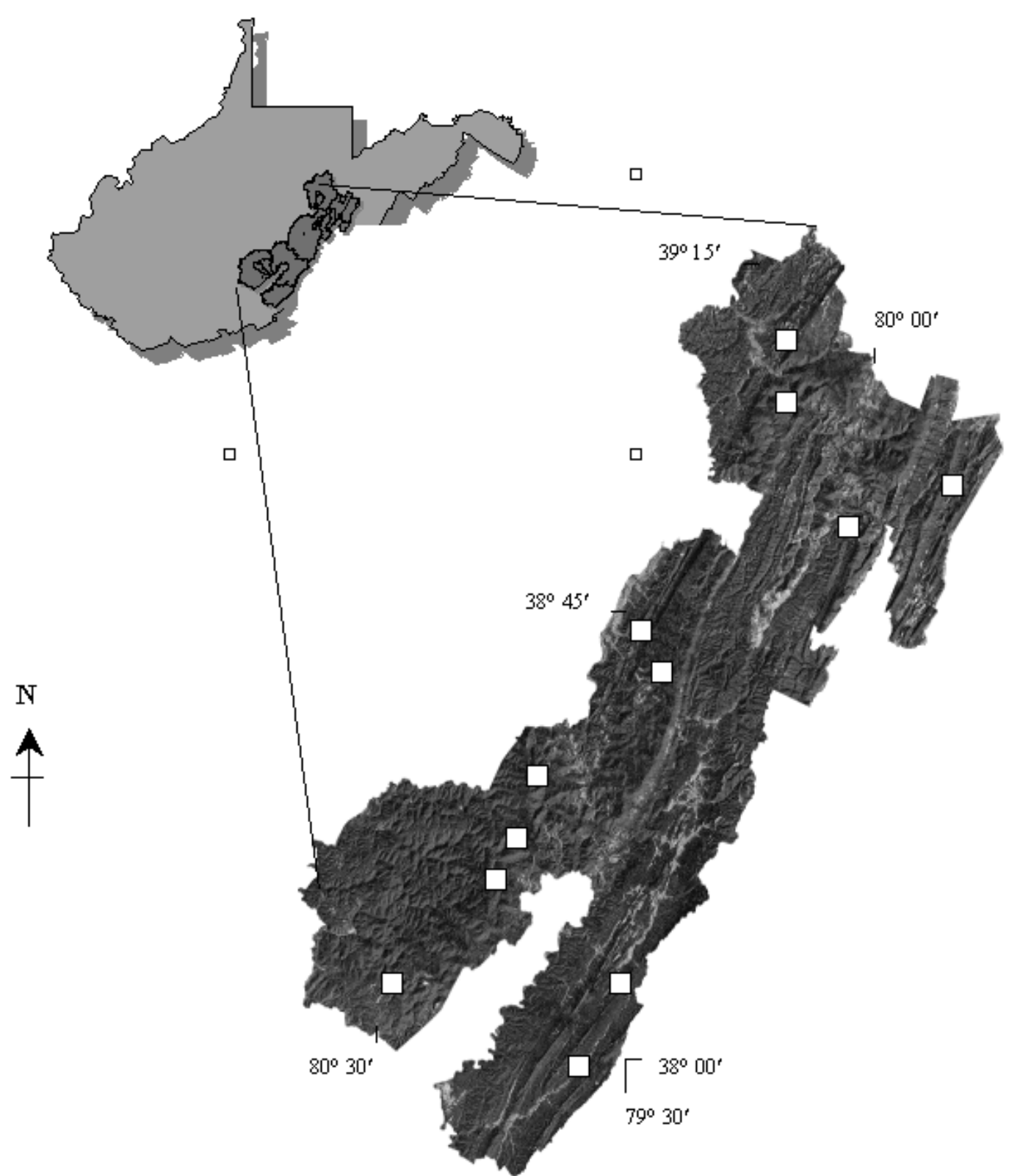

Fig. 3-1. False-color infrared LANDSAT image of the Monongahela National Forest, West Virginia. Nonforested areas are displayed as light blue or pink colors. Deciduous forested areas are bright to dark red; conifers are dark green to black in appearance. White squares indicate locations of the $25 \mathrm{~km} 2$ study areas. The satellite image represents $485,800 \mathrm{ha}(1.2$ million ac). Of this area, $367,611 \mathrm{ha}(908,000 \mathrm{ac})$ are National Forest, the remainder are inholdings of state and private lands. (Adapted from Bender (1999).) 


\section{Sample Study Area - $25 \mathrm{~km}^{2}$}

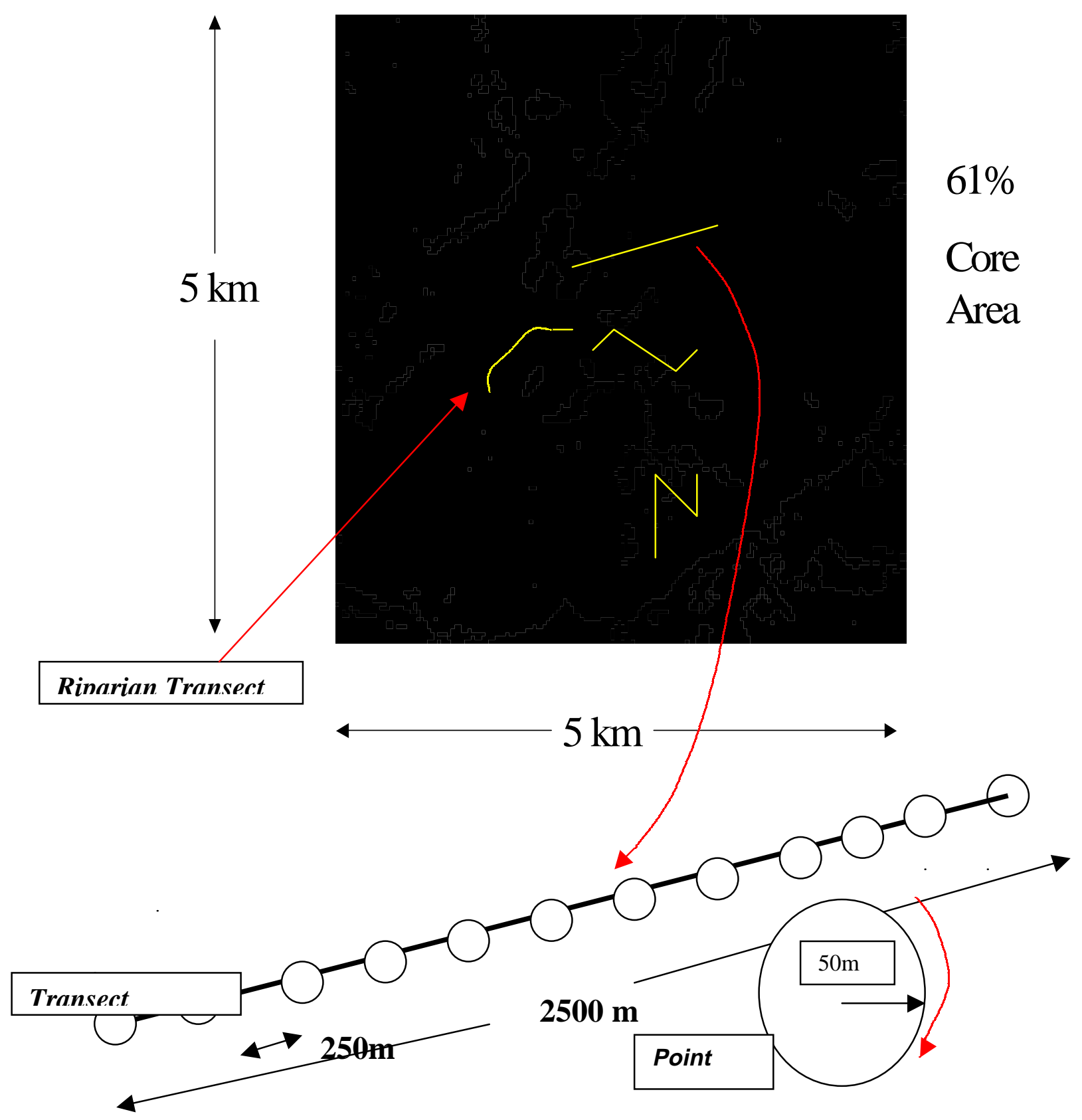

Fig. 3-2. Study design, bird point counts at multiple scales, Monongahela N.F. 


\title{
Chapter 4. Songbird Abundance and Viability At Multiple Scales Across a Range of Fragmented Mixed Mesophytic Landscapes
}

\author{
Abstract. To examine fragmentation effects on songbirds in mixed mesophytic forest, bird \\ abundance and nest survival were quantified in study landscapes differing in degree of \\ fragmentation. Bird point count data were collected on six $25-\mathrm{km}^{2}$ landscapes ranging from \\ $42 \%$ to $81 \%$ forested core area on the Monongahela National Forest, West Virginia during \\ 1996-1997. On five of the landscapes, forty-ha nest-search plots and point count transects \\ were nested within the landscapes; birds could therefore be compared at landscape, plot, and \\ individual nest/point scales. Landscape metrics showed little relation to abundance or \\ viability. Bird abundance varied greatly between transects, possibly because of the great \\ forest heterogeneity of this highly-dissected mountain region. Fragmentation effects were \\ evident at only the local scale. A distinct edge effect was found up to $25 \mathrm{~m}$ from edges; at \\ greater distances the relationship of nest survival to distance from edge was ambiguous. Bird \\ survival varied somewhat with site productivity and forest structural variables. Forest \\ interior bird survival appeared linked to structural diversity. Hooded warblers and wood \\ thrushes were associated with diverse forest understories resulting from edge creation. In \\ this relatively intact forest landscape, local fragmentation and habitat affected survival, and \\ no pervasive landscape-scale effects were evident.
}




\section{Introduction}

Maintaining forest songbird viability is a major biodiversity issue in the eastern United States. Recent Midwestern research is beginning to reveal the population dynamics of songbirds in severely- or moderately-fragmented landscapes, at both local and landscape scales (Donovan et al. 1995a, b, Robinson 1992, Robinson et al. 1995). Research has focused on determining population viability over time and at what scale forest fragmentation may be having an effect. Attention has now turned to the functioning of more intact landscapes (e.g., Hagan et al. 1996), although much remains to be quantified in explaining their role as source areas, and how these landscapes respond to fragmentation.

The Central Appalachians provide some of the largest, most intact forest areas in the East. Consequently, bird populations in West Virginia appear more stable than those in other eastern states (Smith et al. 1992), and the state is likely to play a major role in any regional songbird management strategy (Rosenberg and Wells 1995). At the same time, this region is facing increasing development pressure from highway and pipeline construction, home and service-sector development, and logging. In particular, recreational development and logging on private lands have increased in recent years because of favorable markets.

Within this region, the Monongahela National Forest in the Allegheny Mountains of West Virginia provides large tracts of intact forest. This Forest will soon undergo a planning revision process as called for by the National Forest Management Act of 1976. Accordingly, the time is opportune to revitalize and expand our understanding of songbird-habitat relationships at multiple scales on the Monongahela. A closely-related need is to understand the effects of forest fragmentation on bird abundance and viability. Thus this is an ideal opportunity to describe bird population dynamics in relatively intact forest landscapes. 
Evaluating habitat effects at multiple scales is important, because diversity might be stable or increasing at small areas of extent, yet be declining across the landscape. This comparison at multiple scales remains poorly understood in the region and is of critical importance in developing a viable songbird management strategy.

Identifying bird-habitat associations on the Monongahela revealed the mixed mesophytic forest zone as a forest type of high bird abundance and species richness (Chapter 3). Only the red spruce zone was equivalent in terms of bird abundance and species richness. The mixed mesophytic, however, was clearly superior when nine species of special concern (Partners in Flight 1998) were evaluated. Moreover, this forest type features productive sites that are a focus of logging, medicinal plant collecting, and other uses (Core 1966, Burns and Honkala 1990, McNab and Avers 1994).

Point count data, while providing valuable insight into bird-habitat relationships, cannot answer questions of viability. Nest searching and monitoring during the breeding season has become a widely used method to discern bird survival and productivity (Martin and Geupel 1993, BBIRD 1994, 1996). Used together, the methods provide a powerful assessment of an area's bird abundance and productivity.

\section{Objectives}

The study objective was to compare bird abundance/species richness and viability across a range of moderately-fragmented to intact mixed mesophytic forest landscapes.

By making these comparisons, I sought to identify differences in bird abundance and viability at local, across-landscape, and landscape scales. I further sought to identify whether forest fragmentation typical of the MNF was affecting abundance and viability, and if so, at what scale(s). Specific objectives were as follows: 
1. At landscape, plot/transect, and individual nest/point scales, identify and compare effects of fragmentation (landscape metrics) and habitat variables on bird abundance and nest survival.

2. At the landscape scale, test whether abundance and viability can be related to edge density and forest core area. A clear relationship here implies pervasive, landscape-scale effects.

3. At the plot/transect scale, test for a local fragmentation effect by comparing abundance and nest success with distance to edge, type of edge, distance to water, and plot core area. Relationships here would indicate birds were affected by local fragmentation or proximity to streams.

4. At the point/nest scale, compare the influence of local site factors. Factors included vegetation structural diversity, aspect, plant association, canopy height, and tree diameter classes. Relationships here would indicate site productivity and structural diversity were relating to bird habitat suitability and productivity.

\section{Study Areas}

Six mixed mesophytic study areas, each $5 \mathrm{~km} \mathrm{X} 5 \mathrm{~km}\left(25 \mathrm{~km}^{2}\right)$ in area, were randomly selected across a range from $42 \%$ to $81 \%$ forested core area. Core area was defined as forested area minus a presumed 100-m edge effect (McGarigal and Marks 1995). Sugar maple (Acer saccharum) and red oak (Quercus rubra) characterize mixed mesophytic forest on the Monongahela, typically at elevations below 900m (McNab and Avers 1994, McCay 1994) . Soils are typically well-drained and derived from sandstone or shale. The six study areas feature highly dissected landforms generated through erosion over eons. Thus local relief, and associated forest productivity, varies greatly across the landscape. 


\section{Methods}

I quantified forest songbird abundance and productivity across a range of moderately fragmented mixed-mesophytic landscapes. By co-locating nest search plots and point count transects within larger landscapes, I could examine bird abundance and viability at multiple scales: landscape, nest search plots/transects, and individual nests. I hypothesized identification of the scale(s) with the most influence on birds would have clear implications for both forest planning and bird population viability.

\section{Landscape Metrics}

I used LANDSAT satellite imagery to delineate open versus forested areas. A falsecolor image of each $5 \mathrm{~km}$ by $5 \mathrm{~km}$ study area was reclassified as forest vs. open using an unsupervised approach (Lillesand and Kiefer 1994). Clark University (1995) Idrisi software was used to cluster similar pixels; these groupings were then interpreted as forested or open based on field knowledge of the area. Landscape metrics were then calculated using FRAGSTATS (McGarigal and Marks 1995). Based on experience in analyzing other landscapes throughout the Monongahela, I selected forest core area percent and edge density $(\mathrm{m} / 100$ ha or $\mathrm{m} / \mathrm{ha})$ as those metrics most useful in comparing landscapes. Core area and edge effects have also been associated with changes in nesting survival (Wilcove et al. 1986, Temple and Cary 1988, Paton 1995, Faaborg et al. 1995).

Plot metrics were determined by first precisely locating plot boundaries with a global positioning system (GPS) (Trimble 1995). Plot corners, as well as all edges within plots, were recorded. Edge densities and core areas were determined using ArcView buffering and measurement tools (ESRI 1998). 


\section{Experimental Design}

\section{Point Counts}

Four point count transects were randomly located within each study area. Each transect was $2500 \mathrm{~m}$ long, with points located at $250-\mathrm{m}$ intervals. Transects coincided with the centerline of the nest-search plots. Although located randomly, transects were oriented at approximate right angles to contour lines. This approach was designed to capture the maximum environmental variation possible within logistical constraints. To capture riparian zones, one of the four transects was located along a first-order stream.

Point counts were conducted using standard 50-m radius plots (Ralph et al. 1993). Sampling occurred during the breeding season (May 23-June 30) of 1996 and 1997. All birds heard or seen within a 10-min period were tallied. Fly-overs were counted as within plots if they crossed them during the 10-min period. Observers' abilities to identify birds were verified in the field by a local expert. Data were continually verified as they came in from the field. Each point was sampled twice during the breeding season, approximately 15 days apart. In statistical analyses, I used the greater count of two samples; e.g., if two hooded warblers (Wilsonia citrina) were encountered on the first sampling, and one on the second sampling, the count for analysis purposes was two.

\section{Nest Searching}

In 1996, 40-ha nest search plots were co-located on two of the four point count transects within four of the six $5 \mathrm{~km} \mathrm{X} 5 \mathrm{~km}$ study areas (Fig. 4-1). Because nest search plots followed transects, they were long and narrow (200 m wide and $2000 \mathrm{~m}$ long). In 1997, more resources were available, and two nest-search plots were added at an additional study area, for a total of five of six study areas. All nest search plots followed upland transects. 
Nest searching followed the methodology of the national nest monitoring program (BBIRD 1996). Nests were located in the field, and then revisited at 3-4 day intervals throughout the nesting season (May 24-August 1 in 1996 and May 12-August 1 in 1997) until nestlings fledged or the nest was terminated through predation, abandonment, or adverse weather. The numbers of eggs or nestlings were recorded on each visit, as well as notes on parental location and behavior.

Observers avoided attracting predators to nests by keeping visits brief, and by using alternate approach routes on each visit. Nests were relocated by using a compass bearing and distance to a flagged grid location; flagging at nests was avoided whenever possible.

\section{Vegetation Sampling}

Following the nesting period, vegetation and other environmental data were collected both at each point count center and at each nest using the BBIRD protocol and modified methods of James and Shugart (1970). Variables measured included aspect, number of trees by diameter class, shrub counts, distance to edge, distance to water, canopy height, canopy percent cover, canopy cover for each of six canopy layers, a structural diversity measure reflecting all six layers, and plant association.

I established an 11.3-m radius plot centered on each nest and point count center. Diameter at breast height of all trees on the plot was measured with a diameter tape; trees then were tallied into diameter classes of $2.5-7.5 \mathrm{~cm},>7.5-15 \mathrm{~cm},>15 \mathrm{~cm}-23 \mathrm{~cm},>23-38$ $\mathrm{cm}$, and those greater than $38 \mathrm{~cm}$. Shrub stem density included both shrubs and trees less than $2.5 \mathrm{~cm}$ in diameter, and was tallied on a 5-m radius plot centered on each nest/poimt count center. Distance to edge and distance to water were ocularly estimated in the field, or for long distances, measured on a topographic map. Aspect of each nest was measured with 
a compass. Canopy height over the nest was measured using a clinometer. Canopy percent cover above a nest was ocularly estimated as percentage cover of the 11.3-m-radius plot.

Canopy cover was measured on four 11.3-m transects placed at right angles to each other radiating from the nest. At five 2.25-m intervals along each transect, canopy cover present in the crosshairs of a sight tube was recorded in each of six layers: $0.5-3 \mathrm{~m}, 3.1-6 \mathrm{~m}$, 6.1-12m, 12.1-18 m, 18.1-24 m, and greater than $24 \mathrm{~m}$. Canopy cover for each layer was calculated as the total number of hits (maximum of 20). A structural diversity index equal to the sum of all hits in all layers was also calculated.

Observers identified the plant association (habitat type) at each nest, using a list of plant indicators and their abundance in a dichotomous key. Plant associations vary with site productivity and diversity (Daubenmire 1978, Ferguson et al. 1989), and I hypothesized they would be related to bird survival. I used the plant associations defined by DeMeo (unpub.), based on the work of McCay et al. (1997).

\section{Data Analyses}

Analyses were performed with SAS, version 6.12 (SAS Institute 1996). Effects were considered significant at $\mathrm{p}<0.10$.

For both point counts and nest searching, I analyzed: all birds, the Partners in Flight (PIF) group of nine species (Partners in Flight 1998), and habitat, nesting, and foraging guilds. The list of PIF species was developed by a West Virginia Partners in Flight working group, and are sensitive species or species considered valuable indicators of ecosystem function. They include hooded warbler (Wilsonia citrina), red-eyed vireo (Vireo olivaceus), wood thrush (Hylocichla mustelina), worm-eating warbler (Helmitheros vermivorus), cerulean warbler (Dendroica cerulea), Louisiana waterthrush (Seiurus motacilla), scarlet tanager (Piranga olivacea), eastern wood peewee (Contopus virens), and Acadian flycatcher 
(Empidonax virescens). Habitat guilds were determined using Freemark and Collins (1992).

Nesting and foraging guild membership was determined using Ehrlich et al. (1988).

Analysis of variance (Petersen 1985) was used to compare bird abundance and species richness responses by transect, study area, and riparian effects. The error terms were defined as the nested effect of the higher scales in the hierarchy; e.g., for effects at the transect scale, the error term was the nested effect (interaction) of forest type, riparian status, and study area (block). When an effect was significant (alpah=0.05), means comparisons were performed with the Waller-Duncan k-ratio t-test. Regression was used to test the effect of landscape core area and edge density (as independent variables) on bird abundance (the dependent variable).

Nest survival and clutch size data for 1996 and 1997 were combined. Nest survival estimates were calculated using the Mayfield method (Mayfield 1961, 1975, Hensler and Nichols 1981), using an assumed 15-day incubation period and 12-day brooding (nestling) period. I compared survival estimates among study areas and nest search plots using CONTRAST, a program based on chi-square analyses (Hines and Sauer 1989).

To examine edge effects, nest survival was compared by Paton's (1995) classes: 0-25 m from edge, 26-50 m from edge, 51-75 $\mathrm{m}$ from edge, etc. Comparisons were also made between edge types: open-canopy road, partially open-canopy road, regenerating clearcuts, wildlife openings, and natural gaps.

Clutch sizes were compared among study areas and nest plots using analysis of variance, with the Duncan means comparison when effects were significant $(\mathrm{p}<0.05)$. A summary of all analyses appears in Appendix Table A-4.

At the individual nest scale, logistic regression was used to predict nest outcome (success or failure) as the dependent variable, with distance to edge, plot core area, and distance to 
water as independent variables. Logistic regressions were also performed with nest success or failure dependent on nest-site habitat variables (aspect, canopy height, canopy cover for six canopy layers, the structural diversity index, and tree diameter classes, and plant association). I used only the larger tree diameter classes $(23 \mathrm{~cm}-38 \mathrm{~cm}$ and $>38 \mathrm{~cm})$, because the smaller classes reflected the same data as the lower canopy classes (canopy cover classes 1, 2, and 3). Plant association was entered as a categorical variable, with a code for each association.

To evaluate clutch size at the nest scale, stepwise regression was used to fit the best model possible. Clutch size was the dependent variable, with local fragmentation and on-site variables as independent variables.

\section{Results}

\section{Bird Abundance and Species Richness}

In meeting the objective of comparing bird response between landscapes, I found landscape had little or no effect on bird abundance (Table 4-1) or richness (Table 4-2). For bird abundance, landscape was significant for high canopy nesters $(\mathrm{p}=0.06)$, cavity nesters $(\mathrm{p}=0.02)$, foliage gleaners $(\mathrm{p}=0.07)$, and high canopy foragers $(\mathrm{p}=0.02)$, but had no significant effect overall $(\mathrm{p}=0.46)$ or for any other group (Table 4-1). No significant differences were found in bird abundance/species richness for all birds as a group, Neotropical migrants, resident species, edge species, or forest interior species. Of the 9 individual species examined, only hooded warblers showed a significant landscape effect $(\mathrm{p}=0.05)$ (Table 4-1). For species richness, only bark forager richness varied significantly with landscape $(\mathrm{p}=0.03$, Table 4-2).

In attempting to relate fragmentation effects on bird abundance at the landscape scale, another study objective, I found no relationships between core area $(\mathrm{F}=0.478, \mathrm{p}=0.53)$ or 
edge density $(\mathrm{F}=0.458, \mathrm{p}=0.54)$ of landscapes and bird abundance. Although there were landscape differences within nesting and foraging guilds, there was no relationship with core area or edge density. No differences were found in the Partners in Flight indicator species, with the exception of hooded warblers. Again there was no relationship with core area or edge density. Mean abundance and species richness by bird group/species are shown for each landscape (study area) in Appendix Tables A-11 and A-12.

In contrast to the lack of fragmentation effect at the landscape scale, differences between transects were significant for most groups (Tables 4-1 and 4-2). Overall the effect was significant $(\mathrm{p}=0.0001)$, and was also significant for neotropical migrants and low canopy nesters. Thus, bird abundance and species richness varied greatly between transects, and somewhat surprisingly, was greater than the difference between points on individual transects. The variation between transects is displayed for selected bird groups in Appendix Table A-13.

\section{Nest Survival}

As with point count data, no clear relationship between nest survival and forest fragmentation emerged at the landscape scale. Overall bird survival was greatest at Clover Run and Otter Creek (Table 4-3), the study areas at opposite ends of fragmentation. Neotropical migrants were also equally successful at Clover Run and Otter Creek. Nesting and foraging guilds varied widely or had too low a sample size to analyze (Table 4-3). Clover Run had the greatest survival of the nine PIF species, considered as a group. Wood thrush were associated with greater nest survival in the most fragmented landscapes; in intact landscapes, their numbers were too low to analyze (Table 4-3). Interior/edge species showed the greatest survival at Otter Creek, the most intact landscape, while forest interior 
species showed the greatest survival on more fragmented landscapes (Clover Run and Parsons) (Table 4-3). Edge species' sample sizes were too low to make comparisons.

In determining fragmentation effects on survival at the plot scale, regressions with nest survival for selected bird groups as a response to core area and edge density showed a significant response only for interior-edge species, and then only for plot core area $\left(\mathrm{r}^{2}=0.45\right.$, $\mathrm{p}=0.048$, Figure 4-2). No other models were significant (Table 4-4).

Overall clutch size varied significantly $(\mathrm{F}=2.87, \mathrm{p}=0.02)$ with study area (Appendix Table A-14). Ground gleaner and wood thrush clutch size varied significantly with study area. Clover Run showed the lowest clutch size among neotropical migrants, as well as among interior species (Table 4-5). Other bird groups showed no clear differences or had sample sizes too low to present.

At the plot scale, clutch size showed no relationship with plot core area or edge density

$\left(r^{2}=0.02, p=0.70\right.$ for core area and $r^{2}=0.02, p=0.24$ for edge density). When all species were considered, all nest plots except Otter Creek 2 showed statistically equivalent clutch sizes. Guild comparisons either showed no relationship or could not be analyzed due to low sample sizes.

\section{Individual Nests}

\section{Local Fragmentation Effect (Distance From Edge)}

A key study objective was to determine the local fragmentation effect on nest survival. The greatest number of nests were found within $50 \mathrm{~m}$ of an edge (238 nests of 380 total). Distance to edge had a significant effect on nest success or failure for all species combined, with nests closer to edges more likely to fail $\left(\mathrm{X}^{2}=6.38, \mathrm{p}=0.01, \mathrm{n}=379\right.$, Appendix Table A15). This was also true of neotropical migrants $(\mathrm{p}=0.01)$ and marginally significant for forest 
interior species $(\mathrm{p}=0.06)$ and mixed foragers $(\mathrm{p}=0.07)$. No other guilds showed a relationship with distance to edge.

Nest survival increased significantly from the $0-25 \mathrm{~m}$ to the $26-50 \mathrm{~m}$ class $\left(\mathrm{X}^{2}=38.1\right.$, $\mathrm{p}<0.0001$ ). At greater distances no clear relationship with distance to edge was found (Table 4-6).

To investigate effects of edge contrast, I separated nests by edge type: open canopy road, partially-open canopy road, clearcut, wildlife opening, and natural forest gap (Table 4-7). Sample sizes for paved road edges and distances $>50 \mathrm{~m}$ from an edge were too low for comparisons. Both open-canopy $\left(\mathrm{X}^{2}=3.85, \mathrm{p}=0.0497\right)$ and partially open-canopy road edges $\left(\mathrm{X}^{2}=17.3, \mathrm{p}=0.00001\right)$ showed greater survival $26-50 \mathrm{~m}$ from edges than in the $0-25$ $\mathrm{m}$ zone. For open canopy roads, survival increased until at least $500 \mathrm{~m}$ from an edge (Appendix Table A-16). For regenerating clearcuts, nest survival did not differ between the 0-25 and 26-50 $\mathrm{m}$ zone $\left(\mathrm{X}^{2}=0.22, \mathrm{p}=0.64\right)$. In the $0-25 \mathrm{~m}$ distance class, clearcut edges showed significantly greater survival than any other edge type (Table 4-7). No differences in survival between edge types were found in the $26-50 \mathrm{~m}$ zone.

No edge effects were found to affect clutch size at the individual nest scale. Clutch size averaged 2.89 eggs/clutch $(\mathrm{n}=288)$ regardless of edge type.

\section{Site Habitat Variables}

The effect of local site factors on bird viability (through nest survival) was a study objective at the point scale. Several site variables were related to nesting success or failure (Appendix Table A-17). Survival of low canopy nests was positively related to the second canopy layer ( $3 \mathrm{~m}-6 \mathrm{~m}$ height) (Wald's $\mathrm{X}^{2}=2.88, \mathrm{p}=0.09$ ), and to plant association (Wald's $\mathrm{X}^{2}=5.83, \mathrm{p}=0.02$ ). Nest success of shrub nesters was negatively related to the fourth layer $(12-18 \mathrm{~m})(\mathrm{p}=0.05)$, but positively related to plant association. Neotropical migrant nest 
survival was related only to plant association (Wald's $X^{2}=3.7, p=0.05$ ). Ground gleaner nest survival was associated with aspect, canopy height, and the first canopy layer $(0.5-3 \mathrm{~m})$. Nest survival of foliage gleaners was associated with aspect, canopy height, and plant association. Finally, mixed forager nest survival was associated with the first canopy layer.

Interestingly, nest survival of forest interior species was associated with greater structural diversity: three of six canopy layers, plus overall structure (sum of the six layers) ( $\mathrm{p}<0.05$ for all these variables). Additionally, this group was related to aspect (Wald's $\mathrm{X}^{2}=$ 5.51, $\mathrm{p}=0.02$ ) and canopy height (Wald's $\left.\mathrm{X}^{2}=6.70, \mathrm{p}=0.01\right)$. Edge species' nest survival was not correlated with any habitat variables, and interior/edge only with plant association (Wald's $\mathrm{X}^{2}=5.81, \mathrm{p}=0.02$ ).

Bird groups with nest survival affected by aspect were ground gleaners (Wald's $X^{2}=4.72$, $\mathrm{p}=0.03$ ), foliage gleaners (Wald's $\mathrm{X} 2=6.06, \mathrm{p}=0.01$ ), interior species (Wald's $\mathrm{X}^{2}=5.51$, $p=0.02)$, and wood thrushes $(p=0.08)$. Survial of ground foragers (Wald's $X^{2}=6.49^{\prime} p=0.01$ ), foliage gleaners (Wald's $\mathrm{X}^{2}=6.06^{\prime} \mathrm{p}=0.01$ ), and low canopy nesters (Wald's $\mathrm{X}^{2}=2.28$ $\mathrm{p}=0.09)$ was associated with canopy height. Finally, large trees $(>38 \mathrm{~cm}$ diameter $)$ were associated with nest survival of the PIF group of nine species $(\mathrm{p}=0.08)$.

Plant association had effects on the nest survival of neotropical migrants (marginal at $\mathrm{p}=0.0532)$, low canopy nesters $(\mathrm{p}=0.02)$, shrub nesters $(\mathrm{p}=0.04)$, interior/edge species $(\mathrm{p}=0.02)$, and on the nine PIF species as a group (marginal at $\mathrm{p}=0.08)$ (Appendix Table A17).

\section{Clutch Size}

Few site variables were related to clutch size (Appendix Table A-18). Clutch size of bark foragers was strongly related to density of large trees $\left(\mathrm{r}^{2}=0.70, \mathrm{p}=0.04\right)$. Clutch size of forest interior species was related to presence of canopy layers $12-18 \mathrm{~m}$ and $>24 \mathrm{~m}(\mathrm{p}<0.03$, 
$\left.\mathrm{r}^{2}=0.22\right)$. For shrub nesters, clutch size was significantly related to the shrub layer $(0.5-3 \mathrm{~m}$, $\mathrm{p}<0.01)$, but also to the $12-18 \mathrm{~m}$ layer $(\mathrm{p}=0.06)$. Shrub nesters were also significantly related to plant association $(\mathrm{p}=0.02)$.

\section{Discussion}

I found no clear landscape-scale fragmentation or habitat effect on bird abundance or viability. Most of the variation in bird abundance and species richness was generated by differences between transects across the landscape. This suggests great landscape heterogeneity generated by a wide variety of slope positions and site productivities in a highly dissected landscape. This is important; too often in landscape studies we are tempted to believe forest blocks are uniform. Further evidence for this hypothesis is found in the significance of plant association in explaining nest survival. Because certain plant species are indicative of site conditions, plant associations form useful indicators of site productivity. Certain plant associations in the mixed mesophytic, notably those on cove landforms, are among the most productive on the Monongahela landscape. Others feature a striped maple understory, which favors interior-edge species such as wood thrushes. This is probably the reason why low canopy and shrub nest survival was significantly related to plant association.

The lack of landscape-scale effects implies a lack of area-sensitivity. Abundance of all PIF species except hooded warblers (eight of nine species) was not related to forest core area at the landscape scale (Appendix Table A-12). Recent work by Rosenberg et al. (1999) suggests a lack of area-sensitivity for species in large, intact landscapes, in particular for scarlet tanagers. Robbins et al. (1989), working across a range of forest areas in Maryland, found red-eyed vireo and scarlet tanager abundance to increase with forest area. I found no evidence of this on the Monongahela for either red-eyed vireos or scarlet tanagers, probably because all study landscapes were essentially intact forest with some open areas, whereas 
Robbins et al. (1989) worked across a range of forest sizes in an open matrix generated largely by agriculture and development. In my study, survival and clutch size could not be related to forest core area or edge density at either landscape or plot scales.

Edge effect on nest survival in other studies of forested landscapes has varied widely, from none at all (Hanski et al. 1996, Keyser et al. 1998) to pronounced edge effects (Temple and Cary 1988). Paton (1995) reviewed a number of nest studies and found convincing evidence of an edge effect up to $50 \mathrm{~m}$ from edges, but no clear evidence beyond that. Temple and Cary (1988) demarcated three zones with significantly different nest survival rates: $<100 \mathrm{~m}, 100-200 \mathrm{~m}$, and $>200 \mathrm{~m}$.

In my study, fragmentation began to have an effect at the local scale; distance to edge had a clear effect on survival. Because I analyzed by $25-\mathrm{m}$ intervals, and used natural nests, my work further refines understanding of edge effects. Nests 26-50 $\mathrm{m}$ from an edge had significantly greater survival than those $0-25 \mathrm{~m}$ from an edge; this was true overall, and also for two road edge types. Interestingly, clearcut edges did not show this contrast between the 0-25 $\mathrm{m}$ and 26-50 m zones. For partially-open canopy roads, nest survival generally increased up to $500 \mathrm{~m}$ from edges. This result could not be demonstrated overall, however, or for other edge types. Sample sizes, particularly for nests beyond $200 \mathrm{~m}$ from an edge, may have been too low to detect differences.

Clearcuts in the landscapes I studied had at least some regeneration varying from $1 \mathrm{~m}$ to $10 \mathrm{~m}$ in height. This may have provided some concealment for nests that favored their survival. In contrast, road edges were relatively abrupt, more open to predator search, and more facilitative of predator movement. This may have explained lower survival along road edges. 
Local habitat variables had some effect on nest survival. Perhaps most noteworthy is the significant association of a variety of forest structural measures with nest success of forest interior birds. Also noteworthy is the significance of plant association-a measure of site productivity and diversity with nesting success. In these highly heterogeneous landscapes, more productive plant communities may be serving as "hotspots" for birds in providing more diverse structure, more insects for food and more cover from predators. Although no study has yet linked more insects with more productive sites (Schowalter pers. com.); some studies have shown a greater diversity of insects on more productive sites (e.g., Schowalter 1995).

The relationship between insect abundance and site productivity remains an untested hypothesis, but the identification of clear differences between forest types in Chapter 3, as well as the importance of plant associations within the mixed mesophytic in this study, are strong indications of the importance of different habitat types. Studies of forest fragmentation to this point have generally ignored these differences, either considering all intact forest the same, or focused on differences in land uses (e.g., Bayne and Hobson 1997).

\section{Conservation Implications and Recommendations}

As Hagan et al. (1996) have suggested, large tracts of forest may provide diverse, abundant bird populations because of their resiliency to moderate fragmentation. In these landscapes the largely intact nature of the forest offsets relatively minor fragmentation effects associated with edges and isolation. . Other studies in relatively intact landscapes, including Buford and Capen (1999) (Vermont), Thompson et al. (1992) (Missouri), and Welsh and Healy (1993) (New Hampshire) have come to similar conclusions.

This appears to be true in findings here as well, within the range of fragmentation I studied in the mixed mesophytic forest type. This forest type on the MNF appears to be 
providing valuable habitat to maintain populations of species of concern, notably neotropical migrants and forest interior songbirds.

These findings expand on those of Chapter 3 by confirming the value of the mixed mesophytic forest type for forest songbirds. Moderate fragmentation, resulting in the range of 42 percent core area or greater, does not appear to have adverse effects on bird abundance or viability. Lower clutch sizes at Clover Run (the most fragmented study area), however, may be a warning that this is a threshold beyond which increased fragmentation may begin to adversely affect viability.

Fragmentation effects in these landscapes are local, with a definite edge effect within 25 m of edges. This makes sense in the predominantly forested landscapes of this study, without large areas of agriculture and development, and with small and regenerating clearcuts. Regenerating clearcuts had less adverse effects on nest survival than did roads. Dense vegetation in regenerating clearcuts, typical of sites I studied, may provide more concealment for nesting birds. These findings suggest minimizing road networks and closing roads should be beneficial for songbird nest survival. In addition to creating edge effects, roads also serve as movement corridors for predators and nest parasites.

Finally, these findings can be used as a tool to efficiently identify areas most needed for bird conservation on the Monongahela landscape. Bird-habitat associations described here can be coupled with with recently completed GIS coverages of ecological landtypes to generate maps of predicted bird distribution by species. Such maps can quickly identify bird diversity "hot spots" and should prove an effective tool in designing reserve areas. 


\section{Literature Cited}

Anthony, R.G., G.A. Green, E.D. Forsman, and S.K. Nelson. 1996. Avian abundance in riparian zones of three forest types in the Cascade Mountains, Oregon. Wilson Bull. 108(2):280-291.

Bayne, E.M., and K.A. Hobson. 1997. Comparing the effects of landscape fragmentation by forestry and agriculture on predation of artificial nests. Cons. Biol. 11:1418-1429.

BBIRD. 1994. Breeding Biology Research and Monitoring Database (BBIRD) field protocol. Missoula, MT: Univ. of Montana Coop. Wildl. Res. Unit, 27 pp.

BBIRD. 1996. Breeding Biology Research and Monitoring Database (BBIRD) data entry program, version 0.9. Missoula, MT: Univ. of Montana Coop, 29 pp.

Buford, E.W., and D.E. Capen. 1999. Abundance and productivity of forest songbirds in a managed, unfragmented landscape in Vermont. J. Wildl. Manage. 63(1):180-188.

Burns, R.M., and B.H. Honkala, eds. 1990. Silvics of North America. Washington, DC: USDA For. Serv.

Core, E.L. 1966. Vegetation of West Virginia. Parsons, WV: McClain Printing Co., 217 pp.

Darveau, M., Gauthier, G., J.L. DesGranges, and Y. Mauffette. 1993. Nesting success, nest sites, and parental care of the least flycatcher in declining maple forests. Can. J. Zool.

71:1592-1601.

Darveau, M., P. Beauchesne, L. Belanger, J. Huot, and P. Larue. 1995. Riparian forest strips as habitat for breeding birds in boreal forest. J. Wildl. Manage. 59(1):67-78.

Soc. Bull. 26(1):32-37.

DeMeo, T. 1998. Terrestrial ecological classification of the Monongahela National Forest, West Virginia. On file at USDA For. Serv., Elkins, WV.

Dettmers, R., and J. Bart. 1999. A GIS modeling method applied to predicting forest songbird habitat. Ecol. Appl. 9(1):152-163.

Donovan, T.M., R.H. Lamberson, A. Kimber, F.R. Thompson III, and J. Faaborg. 1995a. Modeling the effects of habitat fragmentation on source and sink demography of neotropical migrant birds. Conserv. Biol. 9(6):1396-1407.

Donovan, T.M., F.R. Thompson III, J. Faaborg, and J.R. Probst. 1995b. Reproductive success of migratory birds in habitat sources and sinks. Conserv. Biol 9:1380-1395. 
Duguay, J.P. 1997. Influence of two-age and clearcut timber management practices on songbird abundance, nest success, and invertebrate biomass in West Virginia. Ph.D. dissertation, West Virginia Univ., Morgantown, 162 pp.

Ehrlich, P.R., D.S. Dobkin, and D. Wheye. 1988. The birder's handbook: A field guide to the natural history of North American birds. New York: Simon and Schuster, Inc., 785 pp.

Faaborg, J., M.C. Brittingham, T.M. Donovan, and J.G. Blake. 1995. Habitat fragmentation in the temperate zone. pp. 357-380 in T.E. Martin and D.M. Finch, eds. Ecology and management of migratory birds: a synthesis and review of critical issues. Oxford University Press, Oxford, England.

Freemark, K., and B. Collins. 1992. Landscape ecology of birds breeding in temperate forest fragments. pp. 443-454 in J.M. Hagan III and D.W. Johnston, eds. Ecology and conservation of neotropical migrant landbirds. Washington, DC: Smithsonian Institution Press.

Gates, J.E., and N.R. Giffen. 1991. Neotropical migrant birds and edge effects at a foreststream ecotone. Wilson Bull. 103(2):204-217.

Hagan, J.M., W.M. vander Haefen, and P.S. McKinley. 1996. The early development of forest fragmentation effects on birds. Conserv. Biol 10(1):188-202.

Hanski, I.K., T.J. Fenske, and G.J. Niemi. 1996. Lack of edge effect in nesting success of breeding birds in managed forest landscapes. Auk 113(3):578-585.

Hensler, G.L., and J.D. Nichols. 1981. The Mayfield method of estimating nesting success: a model, estimators and simulation results. Wilson Bull. 93(1):42-53.

Hodges, M.F., Jr., and D.G. Krementz. 1996. Neotropical migratory breeding bird communities in riparian forests ofdifferent widths along the Altamaha River, Georgia. Wilson Bull. 108(3):496-506.

James, F.C., and H.H. Shugart, Jr. 1970. A quantitative method of habitat description. Audubon Field Notes 24(6):727-736. Wildl. Res. Unit, 27 pp.

Keyser, A., G.E. Hill, and E.C. Soehren. 1998. Effects of forest fragment size, nest density, and proximity to edge on the risk of predation to ground-nesting passerine birds. Conserv. Biol. 12(5):986-994.

Lillesand, T.M., and R.W. Kiefer. 1994. Remote sensing and image interpretation. New York: John Wiley and Sons, 750 pp. 
Martin, T.E., and G.R. Geupel. 1993. Nest-monitoring plots: Methods for locating nests and monitoring success. J. Field Ornithol. 64(4):507-519.

Mayfield, H.F. 1961. Nesting success calculated from exposure. Wilson Bull. 73:255-261.

Mayfield, H.F. 1975. Suggestions for calculating nest success. Wilson Bull. 87(4):456-466.

McCay, D.H., M.D.Abrams, and T.E. DeMeo. 1997. Gradient analysis of secondary forests of eastern West Virginia. J. Torrey Bot. Soc. 124(2):160-173.

McGarigal, K., and B.J. Marks. 1995. FRAGSTATS: spatial pattern analysis program for quantifying landscape structure. Gen.Tech. Rep. PNW-GTR-351. Portland, OR: USDA For. Serv., Pacific Northwest Research Station, 122 pp.

Murray, N.L., and D.F. Stauffer. 1995. Nongame bird use of habitat in Central Appalachian riparian forests. J. Wildl. Manage. 59(1):78-88.

Partners in Flight. 1998. Newsletter of the West Virginia Partners in Flight Working Group. Elkins, WV, Spring 1998.

Paton, P.W.C. 1995. The effect of edge on avian nest success: How strong is the evidence? Pp. 104-113 in D. Ehrenfeld, ed., Readings from Conservation Biology: The landscape perspective. London: Blackwell Science.

Petersen, R.G. 1985. Design and analysis of experiments. New York: Marcel Dekker, 429 pp.

Ralph, C.J., G.R. Geupel, P. Pyle, T.E. Martin, and D.E. DeSante. 1993. Handbook of field methods for monitoring landbirds. Gen. Tech. Rep. PSW-GTR-144. Albany, CA: Pacific Southwest Res. Sta., USDA For. Serv.

Robbins, C.S., D.K. Dawson, and B. Dowell. 1989. Habitat area requirements of breeding forest birds of the Middle Atlantic states. Wildl. Monogr. 103, 34 pp.

Robinson, S.K. 1992. Population dynamics of breeding neotropical migrants in a fragmented Illinois landscape. in J.M. Hagan III and D.W. Johnston, eds. Ecology and conservation of neotropical migrant landbirds. Washington, DC: Smithsonian Institution Press.

Robinson, S.K., F.R. Thompson III, T.M. Donovan, D.R. Whitehead, and J. Faaborg. 1995. Regional effects of forest fragmentation on the nesting success of migratory birds. Science 267: 1987-1990. 
Rosenberg, K.V., and J.V. Wells. 1995. Importance of geographic areas to neotropical migrant birds in the Northeast. Hadley, MA: USDI Fish and Wildl. Serv. Report, 120 pp.

Rosenberg, K.V., J.D. Lowe, and A.A. Dhondt. 1999. Effects of forest fragmentation on breeding tanagers: A continental perspective. Cons. Biol. 13(3):568-583.

Saab, V. 1999. Importance of spatial scale to habitat use by breeding bids in riparian forests: A hierarchical analysis. Ecol. Appl. 9(1):135-151.

SAS Institute. 1996. SAS/STAT user's guide. Cary, NC: Sas Institute, 1028 pp.

Schowalter, T.D. 1995. Canopy invertebrate response to disturbance and consequences of herbivory un temperate and tropical forests. Selbyana 16:41-48.

Smith, C.R., D.M. Pence, and R.J. O'Connor. 1992. Status of neotropical birds in the Northeast: A preliminary assessment. in Status and management of neotropical migratory birds. Fort Collins, CO: USDA For. Serv. Gen. Tech. Rep. RM-229, pp. 172-184.

Temple, S.A., and J.R. Cary. 1988. Modeling dynamics of habitat-interior bird populations in fragmented landscapes. Conserv. Biol. 2(4):340-347.

Thompson, F.R., III, W.D. Dijak, T.G. Kulowiec, and D.A. Hamilton. 1992. Breeding bird populations in Missouri Ozark Forests with and without clearcutting. J. Wildl. Manage. 56:23-30.

Trimble. 1995. Trimble Explorer user's guide. Trimble Corp., Sunnyvale, CA.

Welsh, C.J.E., and W.M. Healy. 1993. Effect of even-aged timber management on bird species diversity and composition in northern hardwoods of New Hampshire. Wildl. Soc. Bull. 21:143-154.

Wilcove, D.S., C.H. McLellan, and A.P. Dobson. 1986. Habitat fragmentation in the temperate zone. pp. 237-256 in M.E. Soule, ed. Conservation biology. Sunderland, MA: Sinauer Assoc. 
Table 4-1. Results of significance tests at multiple scales, Monongahela National Forest bird abundance, 1996-1997.

\begin{tabular}{|c|c|c|}
\hline \multirow[t]{3}{*}{ Bird Group } & \multicolumn{2}{|c|}{$\begin{array}{l}\text { Test for Significant Effect on } \\
\text { Bird Abundance }\end{array}$} \\
\hline & $\begin{array}{l}\text { Landscape } \\
\text { Effect }\end{array}$ & $\begin{array}{l}\text { Transect } \\
\text { Effect }\end{array}$ \\
\hline & F value/df/ $p$ & F value/df/p \\
\hline All Birds & $1.11 / 5 / 0.46$ & $5.23 / 12 / \mathbf{0 . 0 0 0 1}$ \\
\hline \multicolumn{3}{|l|}{ Nesting Guilds } \\
\hline Ground & $1.39 / 5 / 0.36$ & $2.24 / 12 / \mathbf{0 . 0 1}$ \\
\hline High Canopy & $4.53 / 5 / \mathbf{0 . 0 6}$ & $2.10 / 12 / \mathbf{0 . 0 2}$ \\
\hline Cavity & $7.89 / 5 / \mathbf{0 . 0 2}$ & $2.81 / 12 / \mathbf{0 . 0 0 1}$ \\
\hline Low Canopy & $0.76 / 5 / 0.61$ & $2.80 / 12 / \mathbf{0 . 0 0 1}$ \\
\hline Shrub Layer & $2.45 / 5 / 0.17$ & $1.75 / 12 / \mathbf{0 . 0 6}$ \\
\hline \multicolumn{3}{|l|}{ "Migratory Guilds } \\
\hline Neotropical & $1.70 / 5 / 0.29$ & $5.07 / 12 / \mathbf{0 . 0 0 0 1}$ \\
\hline Residents & $0.97 / 5 / 0.51$ & $1.83 / 12 / \mathbf{0 . 0 4 7}$ \\
\hline Short-Distance & $0.42 / 5 / 0.82$ & $1.29 / 12 / 0.23$ \\
\hline \multicolumn{3}{|l|}{ Foraging Guilds } \\
\hline Ground gleaners & $1.39 / 5 / 0.36$ & $2.24 / 12 / \mathbf{0 . 0 1}$ \\
\hline Foliage gleaners & $6.71 / 5 / \mathbf{0 . 0 7}$ & $0.53 / 12 / 0.89$ \\
\hline High canopy & $7.89 / 5 / \mathbf{0 . 0 2}$ & $2.81 / 12 / \mathbf{0 . 0 0 1}$ \\
\hline Bark & $2.25 / 5 / 0.20$ & $1.42 / 12 / 0.17$ \\
\hline Mixed & $0.56 / 5 / 0.73$ & $2.24 / 12 / \mathbf{0 . 0 1}$ \\
\hline \multicolumn{3}{|l|}{ Habitat Guilds } \\
\hline Edge & $0.31 / 5 / 0.89$ & $1.45 / 12 / 0.15$ \\
\hline Interior-Edge & $1.49 / 5 / 0.34$ & $4.56 / 12 / \mathbf{0 . 0 0 0 1}$ \\
\hline Forest Interior & $3.14 / 5 / 0.12$ & $3.74 / 12 / \mathbf{0 . 0 0 0 1}$ \\
\hline \multicolumn{3}{|l|}{ PIF Species } \\
\hline Acadian flycatcher & $1.19 / 5 / 0.43$ & $0.64 / 12 / 0.80$ \\
\hline Cerulean warbler & $0.85 / 5 / 0.57$ & $3.02 / 12 / \mathbf{0 . 0 0 0 6}$ \\
\hline E. wood peewee & $0.55 / 5 / 0.74$ & $1.50 / 12 / 0.12$ \\
\hline Hooded warbler & $5.10 / 5 / 0.049$ & $2.57 / 12 / \mathbf{0 . 0 0 3}$ \\
\hline $\begin{array}{l}\text { Louisiana } \\
\text { waterthrush }\end{array}$ & $0.49 / 5 / 0.77$ & $1.53 / 12 / 0.11$ \\
\hline Red-eyed vireo & $0.62 / 5 / 0.69$ & $2.20 / 12 / \mathbf{0 . 0 1}$ \\
\hline Scarlet tanager & $0.42 / 5 / 0.82$ & $2.39 / 12 / \mathbf{0 . 0 0 6}$ \\
\hline Wood thrush & $0.33 / 5 / 0.88$ & $4.07 / 12 / \mathbf{0 . 0 0 0 1}$ \\
\hline $\begin{array}{c}\text { Worm-eating } \\
\text { warbler }\end{array}$ & $1.02 / 5 / 0.49$ & $1.38 / 12 / 0.18$ \\
\hline
\end{tabular}


Table 4-2. Results of significance tests at multiple scales, Monongahela National Forest bird species richness, 1996-1997.

\begin{tabular}{|c|c|c|}
\hline \multirow{3}{*}{ Bird Group } & \multicolumn{2}{|c|}{$\begin{array}{l}\text { Test for Significant Effect on } \\
\text { Bird Species Richness }\end{array}$} \\
\hline & $\begin{array}{l}\text { Landscape } \\
\text { Effect }\end{array}$ & $\begin{array}{l}\text { Transect } \\
\text { Effect }\end{array}$ \\
\hline & $\begin{array}{l}\text { F value/df/p } \\
\text { value }\end{array}$ & $\begin{array}{l}\text { F value/df/p } \\
\text { value }\end{array}$ \\
\hline All Birds & $0.75 / 5 / 0.62$ & $\begin{array}{l}5.75 / \mathbf{0 . 0 0 0 1} \\
\end{array}$ \\
\hline \multicolumn{3}{|l|}{ Nesting Guilds } \\
\hline Ground nesters & $2.33 / 5 / 0.19$ & $1.65 / 12 / 0.08$ \\
\hline High Canopy & $3.44 / 5 / 0.10$ & $1.30 / 12 / 0.22$ \\
\hline Cavity Nesters & $1.27 / 5 / 0.40$ & $1.54 / 12 / 0.12$ \\
\hline Low Canopy & $0.85 / 5 / 0.57$ & $3.28 / 12 / \mathbf{0 . 0 0 0 2}$ \\
\hline Shrub Layer & $1.49 / 5 / 0.34$ & $1.80 / 12 / \mathbf{0 . 0 5}$ \\
\hline \multicolumn{3}{|l|}{ Migratory Guilds } \\
\hline Neotropical & $1.28 / 5 / 0.40$ & $5.19 / 12 / \mathbf{0 . 0 0 0 1}$ \\
\hline Residents & $0.56 / 5 / 0.73$ & $1.72 / 12 / \mathbf{0 . 0 7}$ \\
\hline Short-Distance & $0.53 / 5 / 0.75$ & $0.80 / 12 / 0.65$ \\
\hline \multicolumn{3}{|l|}{ Foraging Guilds } \\
\hline Ground gleaners & $0.87 / 5 / 0.56$ & $2.13 / 12 / \mathbf{0 . 0 2}$ \\
\hline Foliage gleaners & $0.32 / 5 / 0.88$ & $0.53 / 12 / 0.89$ \\
\hline High canopy & $3.46 / 5 / 0.0998$ & $2.32 / 12 / \mathbf{0 . 0 0 8}$ \\
\hline Bark & $6.36 / 5 / \mathbf{0 . 0 3}$ & $1.84 / 12 / \mathbf{0 . 0 4 8}$ \\
\hline Mixed & $0.59 / 5 / 0.71$ & $3.17 / 12 / \mathbf{0 . 0 0 0 3}$ \\
\hline \multicolumn{3}{|l|}{ Habitat Guilds } \\
\hline Edge & $0.25 / 5 / 0.92$ & $0.94 / 12 / 0.51$ \\
\hline Interior-Edge & $1.20 / 5 / 0.42$ & $3.74 / 12 / \mathbf{0 . 0 0 0 1}$ \\
\hline Forest Interior & $2.53 / 5 / 0.17$ & $3.36 / 12 / \mathbf{0 . 0 0 0 1}$ \\
\hline
\end{tabular}


Table 4-3. Survival estimates for the study areas, combined 1996-1997 data, Monongahela National Forest, WV. Study areas are listed in order of decreasing fragmentation (increasing intactness). Values followed by the same letter are not significantly different at $\mathbf{p}=0.05$. Comparisons were not made (asterisks) when nest sample size was $<10$.

\begin{tabular}{|c|c|c|c|c|c|c|c|c|c|c|c|c|c|c|}
\hline \multirow[b]{2}{*}{ Study Area } & \multicolumn{14}{|c|}{ Nest Survival by Group } \\
\hline & $\begin{array}{l}\text { All } \\
\text { birds }\end{array}$ & $\begin{array}{l}\text { No. } \\
\text { Nests }\end{array}$ & $\begin{array}{l}\text { Neotropical } \\
\text { Migrants }\end{array}$ & $\begin{array}{l}\text { No. } \\
\text { Nests }\end{array}$ & $\begin{array}{l}\text { Short- } \\
\text { Distance }\end{array}$ & $\begin{array}{c}\text { No. } \\
\text { Nests }\end{array}$ & $\begin{array}{l}\text { Low Canopy } \\
\text { Nesters }\end{array}$ & $\begin{array}{c}\text { No. } \\
\text { Nests }\end{array}$ & $\begin{array}{l}\text { Ground } \\
\text { Foragers }\end{array}$ & $\begin{array}{l}\text { No. } \\
\text { Nests }\end{array}$ & Hawking & $\begin{array}{l}\text { No. } \\
\text { Nests }\end{array}$ & $\begin{array}{l}\text { Core } \\
\text { Area } \\
(\%) \\
\end{array}$ & $\begin{array}{l}\text { Edge } \\
\text { Density } \\
\text { (m/100ha) }\end{array}$ \\
\hline Clover Run & $0.39 \mathrm{~A}$ & 101 & $0.41 \mathrm{~A}$ & 74 & $0.40 \mathrm{~A}$ & 22 & $0.43 \mathrm{~A}$ & 62 & $0.33 \mathrm{~A}$ & 41 & $0.36 \mathrm{~A}$ & 12 & 42 & 58 \\
\hline Parsons & $0.27 \mathrm{~B}$ & 78 & $0.27 \mathrm{~B}$ & 74 & $*$ & 2 & $0.26 \mathrm{~B}$ & 52 & $0.14 \mathrm{~B}$ & 34 & $0.46 \mathrm{~B}$ & 15 & 54 & 42 \\
\hline Location & $0.23 \mathrm{~B}$ & 64 & $0.22 \mathrm{~B}$ & 52 & $*$ & 3 & $0.17 \mathrm{C}$ & 30 & $0.18 \mathrm{~B}$ & 12 & $0.47 \mathrm{~B}$ & 17 & 61 & 34 \\
\hline Chestnut Ridge & $0.24 \mathrm{~B}$ & 52 & $0.26 \mathrm{~B}$ & 41 & $0.41 \mathrm{~A}$ & 10 & $0.35 \mathrm{D}$ & 28 & $0.37 \mathrm{~A}$ & 18 & $0.19 \mathrm{C}$ & 17 & 73 & 21 \\
\hline Otter Creek & $0.39 \mathrm{~A}$ & 84 & $0.39 \mathrm{~A}$ & 75 & $*$ & 3 & $0.54 \mathrm{E}$ & 43 & $0.33 \mathrm{~A}$ & 18 & $0.50 \mathrm{~B}$ & 19 & 85 & 8 \\
\hline
\end{tabular}

\begin{tabular}{|c|c|c|c|c|c|c|c|c|c|c|c|c|c|c|}
\hline & \multicolumn{14}{|c|}{ Nest Survival by Group } \\
\hline Study Area & $\begin{array}{l}\text { Mixed } \\
\text { Foragers }\end{array}$ & $\begin{array}{l}\text { No. } \\
\text { Nests }\end{array}$ & $\begin{array}{l}\text { Nine } \\
\text { Species }\end{array}$ & $\begin{array}{l}\text { No. } \\
\text { Nests }\end{array}$ & $\begin{array}{l}\text { Red-eyed } \\
\text { Vireo }\end{array}$ & $\begin{array}{r}\text { No. } \\
\text { Nests }\end{array}$ & $\begin{array}{l}\text { Wood } \\
\text { thrush }\end{array}$ & $\begin{array}{r}\text { No. } \\
\text { Nests }\end{array}$ & $\begin{array}{l}\text { Forest } \\
\text { Interior }\end{array}$ & $\begin{array}{l}\text { No. } \\
\text { Nests }\end{array}$ & $\begin{array}{l}\text { Interior - } \\
\text { Edge }\end{array}$ & $\begin{array}{l}\text { No. } \\
\text { Nests }\end{array}$ & $\begin{array}{l}\text { Core } \\
\text { Area } \\
(\%)\end{array}$ & $\begin{array}{l}\text { Edge } \\
\text { Density } \\
\text { (m/100ha) }\end{array}$ \\
\hline Clover Run & $0.47 \mathrm{~B}$ & 39 & $0.43 \mathrm{~A}$ & 47 & $0.47 \mathrm{~A}$ & 16 & $0.36 \mathrm{~A}$ & 18 & $0.43 \mathrm{~A}$ & 32 & $0.40 \mathrm{~B}$ & 50 & 42 & 58 \\
\hline Parsons & $0.32 \mathrm{~A}$ & 25 & $0.25 \mathrm{~B}$ & 59 & * & 7 & $0.13 \mathrm{~B}$ & 29 & $0.41 \mathrm{AC}$ & 30 & $0.21 \mathrm{C}$ & 41 & 54 & 42 \\
\hline Location & $0.17 \mathrm{C}$ & 25 & $0.19 \mathrm{C}$ & 33 & $*$ & 7 & $*$ & 7 & $0.35 \mathrm{BC}$ & 30 & $0.12 \mathrm{D}$ & 19 & 61 & 34 \\
\hline Chestnut Ridge & $0.29 \mathrm{~A}$ & 16 & $0.30 \mathrm{~B}$ & 16 & $*$ & 4 & $*$ & 8 & $0.17 \mathrm{D}$ & 14 & $0.36 \mathrm{~B}$ & 34 & 73 & 21 \\
\hline Otter Creek & $0.37 \mathrm{~A}$ & 39 & $0.35 \mathrm{~B}$ & 28 & $0.60 \mathrm{~A}$ & 11 & $*$ & 7 & $0.29 \mathrm{~B}$ & 32 & $0.50 \mathrm{~A}$ & 38 & 85 & 8 \\
\hline
\end{tabular}


Table 4-4 . The relationship of total nest survival to core area and edge density at the plot scale, 1996-1997 seasons, Monongahela National

Forest. The only significant relationship among the models is that of interior-edge species survival with increasing core area $(r 2=0.45$, $\mathbf{p}=\mathbf{0 . 0 4 8})$.

\begin{tabular}{|l|l|l|l|l|}
\hline \hline & \multicolumn{2}{|l|}{ Core Area } & Edge Density \\
\hline Bird Group & $\mathbf{r}^{2}$ & $\mathbf{p}$ & $\mathbf{r}^{2}$ & $\mathrm{p}$ \\
\hline \hline All Birds & 0.10 & 0.41 & 0.02 & 0.75 \\
\hline $\begin{array}{l}\text { Neotropical } \\
\text { migrants }\end{array}$ & 0.24 & 0.18 & 0.12 & 0.37 \\
\hline Forest interior & 0.20 & 0.27 & 0.11 & 0.42 \\
\hline Interior-edge & $\mathbf{0 . 4 5}$ & $\mathbf{0 . 0 4 8}$ & 0.34 & 0.11 \\
\hline \hline
\end{tabular}


Table 4-5. Mean clutch size comparison of reference areas, combined 1996-1997 data on Monongahela National Forest study areas.

\begin{tabular}{|c|c|c|c|c|c|c|c|}
\hline & \multicolumn{7}{|c|}{ Clutch Size by Group } \\
\hline Reference Area & All birds & $\begin{array}{l}\text { No. } \\
\text { Nests }\end{array}$ & $\begin{array}{l}\text { Neotropical } \\
\text { Migrants }\end{array}$ & $\begin{array}{l}\text { No. } \\
\text { Nests }\end{array}$ & $\begin{array}{l}\text { Short Dis. } \\
\text { Residents }\end{array}$ & $\begin{array}{r}\text { No. } \\
\text { Nests }\end{array}$ & $\begin{array}{l}\text { Increasing } \\
\text { Fragmentation }\end{array}$ \\
\hline Clover Run & $\begin{array}{ll}2.60 & \mathrm{~B} \\
\end{array}$ & $\overline{c 75}$ & $2.61 \mathrm{C}$ & $4 \quad 46$ & 2.42 & $\begin{array}{l}36 \\
\end{array}$ & \\
\hline Parsons & $3.00 \mathrm{~A}$ & 72 & $3.01 \mathrm{AB}$ & 69 & 3.00 & 6 & \\
\hline Location & $2.88 \mathrm{AB}$ & 52 & $2.98 \mathrm{AB}$ & 45 & 1.67 & 9 & \\
\hline Chestnut Ridge & $2.92 \mathrm{AB}$ & 39 & $2.90 \mathrm{~B}$ & 30 & 2.60 & 15 & \\
\hline Otter Creek & $3.16 \mathrm{~A}$ & 50 & $3.18 \mathrm{~A}$ & 54 & 2.50 & 6 & \\
\hline
\end{tabular}

\begin{tabular}{|c|c|c|c|c|c|c|c|c|c|}
\hline & \multicolumn{9}{|c|}{ Clutch Size by Group } \\
\hline Reference Area & Edge & $\begin{array}{l}\text { No. } \\
\text { Nests }\end{array}$ & $\begin{array}{l}\text { Interior/ } \\
\text { Edge }\end{array}$ & $\begin{array}{l}\text { No. } \\
\text { Nests }\end{array}$ & Interior & $\begin{array}{r}\text { No. } \\
\text { Nests }\end{array}$ & $\begin{array}{l}\text { Wood } \\
\text { thrush }\end{array}$ & $\begin{array}{r}\text { No. } \\
\text { Nests }\end{array}$ & $\begin{array}{l}\text { Increasing } \\
\text { Fragmentation }\end{array}$ \\
\hline Clover Run & $2.75 \mathrm{~B}$ & 12 & $\begin{array}{ll}2.63 & \mathrm{~B} \\
\end{array}$ & 35 & $2.37 \mathrm{~B}$ & 19 & $2.58 \quad \mathrm{~B}$ & 19 & $\mathbf{A}$ \\
\hline Parsons & $3.00 \mathrm{~B}$ & 5 & $3.10 \mathrm{~A}$ & 39 & $2.88 \mathrm{~A}$ & 26 & $3.09 \mathrm{AB}$ & 32 & \\
\hline Location & $3.71 \quad \mathrm{~A}$ & 7 & $2.65 \mathrm{~B}$ & 17 & $2.83 \mathrm{~A}$ & 24 & $2.71 \quad \mathrm{~B}$ & 7 & \\
\hline Chestnut Ridge & $3.33 \mathrm{BA}$ & 3 & $2.75 \mathrm{~B}$ & 20 & $2.92 \mathrm{~A}$ & 12 & $2.29 \mathrm{~B}$ & 7 & \\
\hline Otter Creek & $3.22 \mathrm{BA}$ & 9 & $3.14 \mathrm{~A}$ & 21 & $3.13 \mathrm{~A}$ & 16 & $3.88 \mathrm{~A}$ & 8 & \\
\hline
\end{tabular}


Table 4-6. Nest survival by distance from edge (DTE) class, Monongahela National Forest study areas, 1996-1997. Edge classes follow those of Paton (1995). Values followed by the same letter are not significantly different at $p=0.05$. Asterisk indicates not used in statistical comparisons because of low sample size.

\begin{tabular}{|l|l|l|l|l|l|}
\hline \hline DTE Class & No. Nests & $\begin{array}{l}\text { Incubation } \\
\text { Losses }\end{array}$ & $\begin{array}{l}\text { Brooding } \\
\text { Losses }\end{array}$ & Total Survival & $\begin{array}{l}\text { Variance of } \\
\text { Total Survival }\end{array}$ \\
\hline \hline $0-25 \mathrm{~m}$ & 184 & 56 & 30 & $0.29 \mathrm{~A}$ & 0.0001 \\
\hline $26-50 \mathrm{~m}$ & 54 & 13 & 9 & $0.42 \mathrm{~B}$ & 0.0004 \\
\hline $51-75 \mathrm{~m}$ & 15 & 5 & 5 & $0.22 \mathrm{C}$ & 0.0008 \\
\hline $76-100 \mathrm{~m}$ & 26 & 5 & 4 & $0.42 \mathrm{~B}$ & 0.0008 \\
\hline $101-200 \mathrm{~m}$ & 36 & 10 & 7 & $0.30 \mathrm{~A}$ & 0.0005 \\
\hline $201-300 \mathrm{~m}$ & 15 & 5 & 2 & $0.26 \mathrm{AC}$ & 0.0013 \\
\hline $301-500 \mathrm{~m}$ & 19 & 2 & 4 & $0.45 \mathrm{~B}$ & 0.0012 \\
\hline $501-1000 \mathrm{~m}$ & 18 & 5 & 3 & $0.14 \mathrm{E}$ & 0.0009 \\
\hline $1001-1500 \mathrm{~m}$ & 10 & 0 & 0 & $1.00 \mathrm{~F}$ & 0.0000 \\
\hline$>1500 \mathrm{~m}$ & $1^{*}$ & 0 & 0 & 1.00 & 0.0000 \\
\hline \hline
\end{tabular}


Table 4-7. Comparison of nest survival on forest edges (0-25 m distance from edge) among edge types, Monongahela National Forest study areas, 19961997. Values within a column followed by the same letter are not significantly different at $\mathbf{p}=0.05$.

\begin{tabular}{|l||l|l|l||l|l|l|}
\hline \hline Edge Type & $\begin{array}{l}\text { No. } \\
\text { Nests }\end{array}$ & $\begin{array}{l}\text { Total } \\
\text { Survival }\end{array}$ & Variance & $\begin{array}{l}\text { No. } \\
\text { Nests }\end{array}$ & $\begin{array}{l}\text { Total } \\
\text { Survival }\end{array}$ & Variance \\
\hline \hline & \multicolumn{2}{|l|}{ Distance class 0-25 $\boldsymbol{m}$ from edge } & \multicolumn{2}{|l|}{ Distance class 26-50 $\boldsymbol{m}$ from edge } \\
\hline \hline Open Canopy Road & 43 & $0.29 \mathrm{~B}$ & 0.0004 & 21 & $0.36 \mathrm{~A}$ & 0.0010 \\
\hline $\begin{array}{l}\text { Partially-Open Canopy } \\
\text { Road }\end{array}$ & 53 & 0.21 CD & 0.0003 & 13 & $0.38 \mathrm{~A}$ & 0.0014 \\
\hline \hline Regenerating Clearcut & 49 & $0.41 \mathrm{~A}$ & 0.0004 & 15 & $0.43 \mathrm{~A}$ & 0.0012 \\
\hline \hline Wildlife Opening & 14 & $0.25 \mathrm{BCD}$ & 0.0015 & $2 *$ & & \\
\hline Natural Forest Gap & 11 & $0.18 \quad \mathrm{D}$ & 0.001 & $0^{*}$ & & \\
\hline \hline
\end{tabular}




\section{Sample Study Area -25 km²}

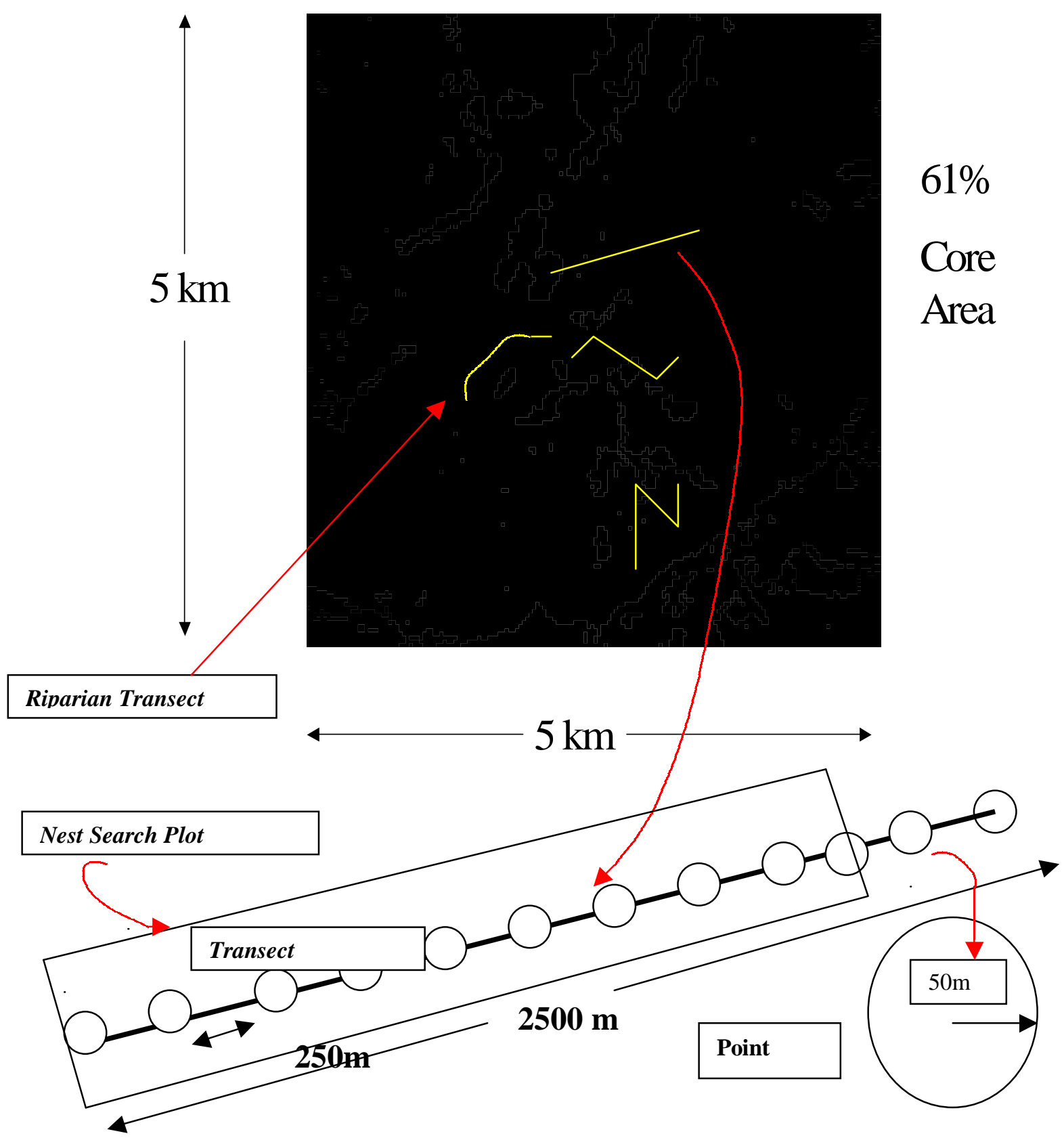

Fig. 4-1. Study design, bird point counts and nest search plots at multiple scales, Monongahela N.F. Nest search plots are $200 \mathrm{~m}$ wide and $2000 \mathrm{~m}$ long. Two nest search plots occur in each study landscape. 


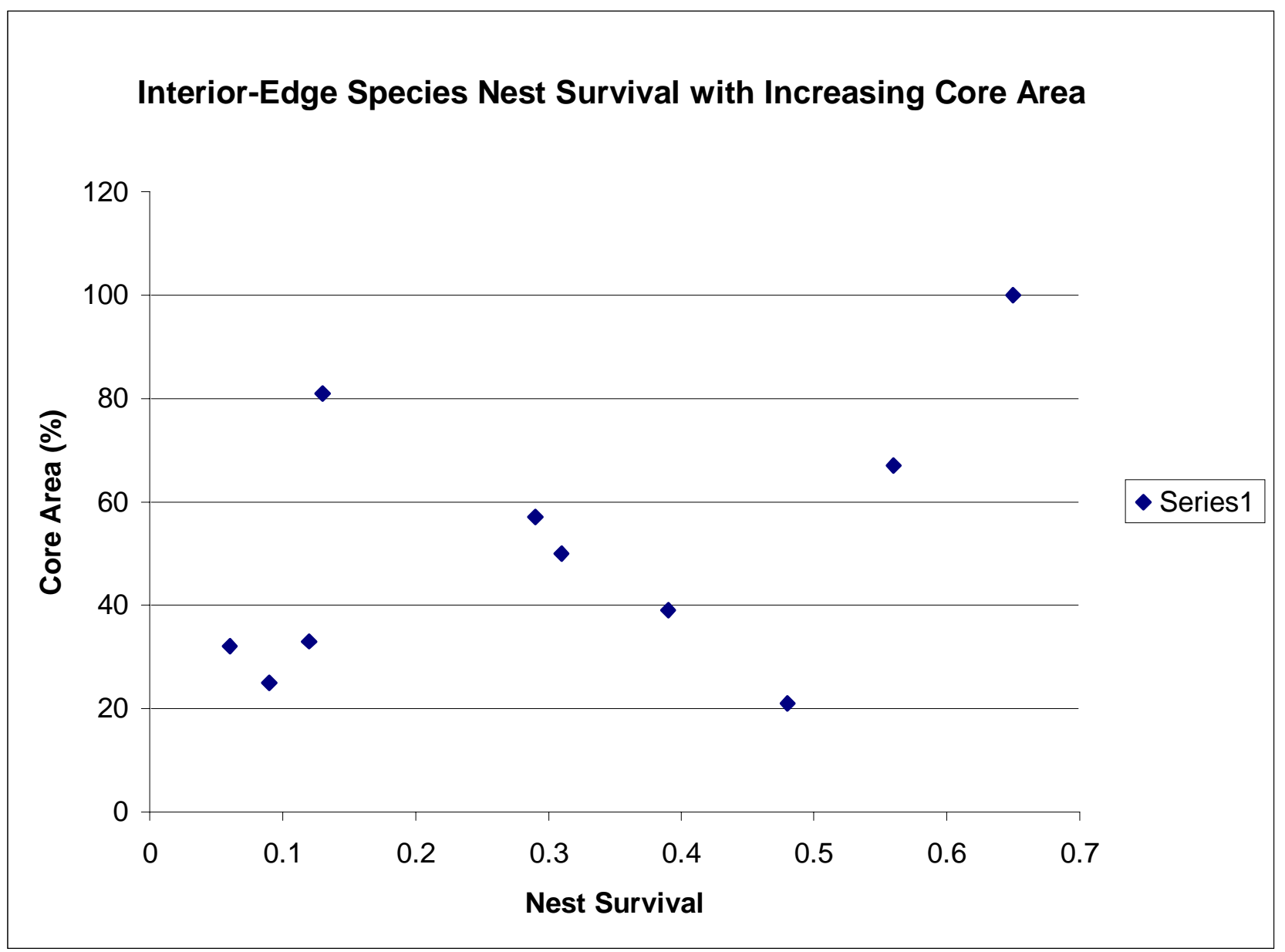

Figure 4-2. The relationship of interior-edge species nest survival to plot core area $(r 2=0.45, p=0.048), n=10$ plots. 


\title{
Chapter 5. Forest Songbird Abundance in Riparian versus Upland Habitat at Multiple Scales on the Monongahela National Forest, West Virginia
}

\begin{abstract}
Riparian zones can have special values as bird habitat. I investigated songbirdriparian habitat relationships at multiple scales in four major forest types of the Monongahela National Forest, West Virginia. Landscape $\left(25 \mathrm{~km}^{2}\right)$, transect $(2500 \mathrm{~m})$, and point (50-m radius point count plot) scales were used in a nested design. Within each landscape bird abundance and species richness were sampled with point counts along randomly-selected first-and second-order mountain streams. I also sampled along randomly-selected upland transects in the same landscapes.

Overall, more birds were found on upland than riparian sites. Further examination revealed this difference was due to greater abundance of mixed foragers and interior-edge species; all other guilds showed no difference in upland versus riparian abundance. Proximity to streams had little effect on explaining abundance of bird groups; in fact, some species' abundance increased with increasing distance from water. Abundance of four species was greater near streams, however: Acadian flycatcher, Louisiana waterthrush, wood thrush, and hooded warbler. While some measures of vegetation and other environmental variables differed between riparian and upland sites, contrasts are not sharp and are inadequate to explain differences in upland versus riparian bird abundances. Results agree with those of similar studies in forested landscapes lacking contrast between streamside zones and adjacent uplands.
\end{abstract}




\section{Introduction}

Riparian zones are often considered to have special value as bird habitat. The relative value of streamside areas for birds appears to depend on the degree of contrast with the surrounding landscape. In agricultural or savanna landscapes with narrow wooded strips along streams, riparian zones often serve as bird "hotspots." In contrast, forested landscapes had no difference in bird diversity between upland and riparian zones (Murray and Stauffer 1995, Darveau et a 1. 1995), or had greater numbers of birds on upland sites (McGarigal and McComb 1992).

Multiple scales must be considered in planning for the viability of wildlife populations (Harris 1984, Noss and Cooperrider 1994, Freemark et al. 1995). Management of species at the local (e.g., forest stand) scale is no longer considered adequate (Kessler et al. 1992, Freemark et al 1995), because ecosystem processes and habitats are linked (Harris 1984, Soule and Simberloff 1986, Simberloff 1988, Noss 1992). An understanding of how riparian zones contribute to overall landscape diversity is sound conservation planning, particularly since these zones are often considered "keystone" components of forested landscapes (Gregory et al. 1991, Noss and Cooperrider 1994). For forest songbirds, all habitats are not of equal quality, since birds tend to select some over others because of better opportunities for feeding, successful reproduction, and dispersal (Freemark et al. 1995).

The Monongahela National Forest (MNF) covers 367,611 ha of east-central West Virginia, in the heart of a region thought to be an important source area for migratory 
songbirds, particularly those associated with forest-interior and interior-edge conditions (Rosenberg and Wells 1995). Because management of streamside zones on the MNF is an important issue, and because the Forest's administration will face a Forest plan revision in the near future, information on the relative value of riparian zones as bird habitat will be useful and timely.

Comparisons of nested point, transect, and landscape scales (Chapter 3) identified significant effects of forest type, transect, and upland versus riparian differences. In this chapter I focus on further exploring the upland versus riparian differences.

\section{Objectives.}

To meet this information need, I compared bird abundance and species richness on riparian and upland transects. Habitat relationships were investigated at three nested scales:

point count locations along transects, in turn located within $25 \mathrm{~km}^{2}$ study areas (landscapes). Study scope encompassed the four major forest zones of the MNF.

The specific study objectives are:

1) At the landscape scale, compare differences between forest types and test for a forest type-riparian interaction; and

2 ) At the transect and point scales, compare the importance of proximity to streams with other habitat factors, such as slope, aspect, elevation, and vegetation cover at different canopy layers. 


\section{Study Areas}

In 1996, three study areas, each $25 \mathrm{~km}^{2}$ in area, were randomly selected for each of the four major forest types on the Monongahela National Forest (mixed mesophytic, northern hardwoods, red spruce, and dry oaks) (Appendix Table A-1). Mixed mesophytic forests are characterized by sugar maple (Acer saccharum) and red oak (Quercus rubra), typically at elevations below $900 \mathrm{~m}$ in the Allegheny Mountains (Core 1966). Northern hardwoods occur at higher elevations (900 to $1150 \mathrm{~m}$ ), are generally less productive, and are characterized by American beech (Fagus grandifolia). Red spruce (Picea rubens) forest occurs at the highest elevations (1150 to $1240 \mathrm{~m}$ ) and is characterized by cold soils and a relatively short growing season. Dry oaks, in contrast to the other three types, predominate in the eastern (Ridge and Valley) portion of the Monongahela, which has a markedly drier climate, thus limiting forest productivity. Vegetation there is characterized by white (Quercus alba) and chestnut oak (Quercus montana), with scarlet (Quercus velutina) and black oaks (Quercus coccinea) on drier sites, and the "dry pines" (table mountain (Pinus pungens), pitch (Pinus rigida), and Virginia pine (Pinus virginiana)) on the poorest sites.

\section{Methods}

\section{Experimental Design}

At the landscape scale, I randomly selected three $5 \mathrm{~km} \mathrm{X} 5 \mathrm{~km}$ study areas (each with a minimum of 60 percent forest core area) in each of the four major forest types (mixed mesophytic, northern hardwoods, red spruce, and dry oaks), for a total of 12 study areas. 
Four transects per study area were sampled, three upland and one riparian. One riparian transect out of four was included as a rough estimate of riparian abundance across the landscape. Because each transect averaged 11 points, each study area contained approximately 33 upland points and 11 riparian points. Although these numbers varied somewhat because of logistical constraints, I maintained the same proportion of upland and riparian points per study area.

At the transect scale, sample points (an average 11 per transect) were nested along transects $2500 \mathrm{~m}$ in length, with a point at the transect start, and subsequent points at $250-\mathrm{m}$ intervals (Appendix Table A-1). To obtain a broad scope of inference, I oriented transects at right angles to contour lines, thus capturing variation due to elevation. Riparian transects were also typically composed of 11 points, but followed first or second order streams. All riparian sampling took place within $50 \mathrm{~m}$ of streams.

At the point scale, I measured bird abundance and richness using standard 50-m radius, 10-minute point counts (Ralph et al. 1993). Sampling occurred during the breeding season (May 23-June 30) of 1996 and 1997.

Because the sound of flowing water can obscure bird songs, and May 1996 had extremely high rainfall, I used a subset of the point count data to compare days with at least $0.25 \mathrm{~cm}$ rainfall versus days with no recorded rainfall. Rainfall data were available from the Elkins, WV airport, so only point counts within the vicinity of Elkins were used. Fifty-one point count stations (34 in 1996 and 13 in 1997) had no rainfall on one count and $>0.25 \mathrm{~cm}$ on the other. Paired-difference t-tests indicated no differences in bird abundance on days with rain 
versus those without rainfall $(\mathrm{t}=2.035, \mathrm{df}=33, \mathrm{p}<0.05$ in $1996 ; \mathrm{t}=2.009, \mathrm{df}=12, \mathrm{p}<0.05$ in 1997).

\section{Site Data}

For each 50-m radius point count plot, two $11.3-\mathrm{m}$ radius vegetation plots were sampled using methods modified from James and Shugart (1970). Variables measured included distance to water, canopy height, canopy percent cover, rhododendron (Rhododendron maximum) percent cover, site aspect, elevation, canopy cover for each of six canopy layers, and percent conifer cover. Canopy cover for each of six canopy layers was also determined using a sighting tube.

Observers identified the plant association (habitat type) at each point, using a list of plant indicators and their abundance in a dichotomous key. Plant associations vary with site productivity and diversity (Daubenmire 1978, Ferguson et al. 1989); I hypothesized they might explain variation in bird abundance and species richness. I used the plant associations defined by DeMeo (1998), based on the work of McCay et al. (1997). Aspect at each point was measured with a compass. Distance to water was ocularly estimated in the field, or for long distances, determined from a topographic map.

\section{Data Analysis}

Analyses were performed with SAS (SAS Institute 1988). Differences were considered significant at $\mathrm{p}<0.05$. For stepwise multiple regressions relating habitat variables to bird abundance response, variables entered models at $\mathrm{p}=0.15$. Response variables were bird 
abundance and species richness per point. compared these using a variety of groupings: 1) all birds sampled; 2) nesting, migratory, foraging, and habitat guilds (Freemark and Collins 1992); and individual species of interest. For species of interest, I used nine species considered monitoring indicators by the West Virginia Partners in Flight (PIF) initiative (Partners in Flight 1998): cerulean warblers, worm-eating warblers, red-eyed vireos, wood thrushes, hooded warblers, Acadian flycatchers, Louisiana waterthrushes, scarlet tanagers, and eastern wood peewees, as well as the 10 most common species detected on point counts (Appendix Table A-3).

\section{Landscape Scale}

I compared upland versus riparian abundance and species richness between forest types using analysis of variance and Duncan-Waller-Bayes means separation procedures.

\section{Transect Scale}

I investigated the importance of proximity to streams versus other habitat variables at the transect scale, using stepwise multiple regression. The average distance of sampling points from the nearest stream per transect was used, and is therefore an indirect measure of stream density (number of streams per unit area) across a landscape. Negative distance to water (DTW) values indicate closer proximities to water. Bird abundance was used as a response variable to independent habitat variables, using the average value of distance to water (DTW) per transect. Cerulean warblers (Dendroica cerulea), hooded warblers (Helmitheros vermivorus), Louisiana waterthrushes (Seiurus motacilla), and yellow-billed cuckoos (Coccyzus americanus) were rarely detected (Appendix Table A-6). For these less common 
species of interest, logistic regression was used, rather than stepwise regression. Logistic regression uses presence/absence as the response variable (in this case, count), and is effective with small sample sizes (Kachigan 1986). Analyses were only performed when data for at least five birds for a species were available for the forest type of interest (Appendix Table A-6).

\section{Site Influences (Point Scale)}

Stepwise multiple regression techniques were also used to compare effects of habitat variables on upland versus riparian bird abundance. For each forest type, I grouped birds as all birds, by migratory guilds, and by habitat guilds. I also used average abundance per transect (average of the point abundances on a transect) for the ten most abundant species in each forest type (Appendix Table A-3). Bird abundance was used as a response variable to independent habitat variables.

These variables included distance to water (DTW), slope (SLOPE), aspect (ASPECTT), elevation above sea level (ELEV), overstory conifer cover (OSCON), understory conifer cover (USCON), combined overstory and understory conifer cover (SUMCON), stand height (STANDHT), and rhododendron cover (RHMA). I also used canopy cover at each of six layers (CAN1, CAN2 ...CAN6). Finally, I included a structural diversity score (SDIALL) reflecting the sum of canopy covers for the six layers. Aspect data were transformed to a scale from 0 to 2 using the formula transformed aspect $=\cos ($ aspect -45$)+1$ (Beers et al. 1966). On this scale values near 1 indicate "northeastness," and hence cool, moist sites. 
Percent cover data were transformed using arcsin(square root of ( percent cover X 0.01)) (Zar 1984).

\section{Results}

\section{Landscape Scale}

Overall, more birds and more species were found on upland rather than riparian habitats (Table 5-1). The riparian-forest type interaction was not significant for either bird abundance $(\mathrm{F}=0.31, \mathrm{p}=0.82)$ or species richness $(\mathrm{F}=0.46, \mathrm{p}=0.71)$.

Within all nesting, migratory, and foraging guilds no differences were found in species richness between upland and riparian sites, except for shrub nesters; this group had greater richness on upland sites (Table 5-1). This was also true for bird abundance, with the exception of mixed foragers, where abundance was greater on upland sites. Forest interior and interior-edge species had greater richness on upland sites than in riparian zones. Edge species showed no difference between upland and riparian sites.

For selected species of interest, Cerulean warblers and scarlet tanagers were more common on upland sites (Table 5-1). Wood thrushes, hooded warblers, Acadian flycatchers, and Louisiana waterthrushes were more common along streams. Red-eyed vireos and eastern wood peewees did not differ between upland and riparian zones.

Birds were more abundant and diverse on upland than on riparian sites in all forest types except dry oaks, where there was no difference in abundance $(\mathrm{p}<0.05$, Table 5-2). More bird 
species were found on upland than on riparian sites in northern hardwoods and red spruce. In mixed mesophytic and dry oaks there was no difference.

\section{Transect Scale}

When abundance of the ten most abundant species in each forest type was related to proximity to water, only four species showed a significant $(\mathrm{p}<0.10)$ relationship: Acadian flycatcher, red-eyed vireo, dark-eyed junco, and eastern wood peewee (Table 5-3). Acadian flycatcher and dark-eyed junco abundance was favored by proximity to water (negative DTW values), while red-eyed vireos and wood peewees were more abundant as distance from water increased. (These relationships were not true in all forest types, however.)

With uncommon species, cerulean warblers and yellow-billed cuckoos avoided water (positive DTW values), and Louisiana waterthrushes and hooded warblers were favored by its proximity (negative DTW values) (Table 5-4).

\section{Point Scale}

When habitat variables such as elevation, slope, canopy covers, etc. are related to upland and riparian sites, few striking differences emerge (Tables 5-5 and 5-6). More birds were found at lower mixed mesophytic locations on both upland and riparian sites. Even in cases where there were strong habitat differences between upland and riparian sites, these differences were generally not related to bird abundance (Table 5-6). None of the habitat variables sampled in red spruce had a significant effect on bird abundance; and only elevation was related to bird abundance in mixed mesophytic and dry oaks. 
Abundance of Acadian flycatchers, Louisiana waterthrushes, dark-eyed juncos, and hooded warblers was significantly greater in riparian zones (Table 5-1). Red-eyed vireos, cerulean warblers, yellow-billed cuckoos, and eastern wood peewees were more abundant on upland sites.

\section{Comparison of Bird Abundance Between Transect and Point Scales.}

Bird abundance responses at both transect and point scales show little influence of proximity to streams (Tables 5-3, 5-4, 5-5). Proximity to water (-DTW) was not significantly related to abundance of any bird group, but was for some species, such as Acadian flycatchers. Some bird groups increased in abundance with greater distance from streams (e.g., all birds on red spruce transects).

\section{Discussion}

Overall, more birds and more species were found on upland than on riparian sites (Table 5-1). This was true at point, transect, and landscape scales. Further examination, however, revealed that this was due to greater abundance of interior-edge and mixed foraging birds on upland sites. All other guilds showed no difference in abundance between upland and riparian sites (Table 5-1).

In the mixed mesophytic, birds may in some cases be avoiding riparian zones because of habitat features, notably rhododendron . Although there were a number of habitat differences between upland and riparian sites (Table 5-6), these differences were generally not reflected in bird abundances. One exception may be elevation, associated with greater abundances at lower elevation in the mixed mesophytic and dry oaks. In at least one other 
riparian study (Finch 1991), elevation was found as an important habitat variable affecting bird abundances.

- Studies showing a strong riparian effect on birds usually are from landscapes where a forested riparian strip occurs in a mostly open landscape (Gates and Giffen 1991, Darveau et al. 1995), or where there is significant contrast between vegetation types (Anthony et al. 1996, Hodges and Krementz 1996, Saab 1999).

In coniferous forest landscapes of the Pacific Northwest, McGarigal and McComb (1992) found more birds in upland habitats than along streams. They attributed this difference to the abundance of cavity-nesters in the more abundant snags found on upland sites. In this study, however, I found no evidence of more abundant cavity nesters on upland versus riparian sites $(\mathrm{F}=0.42, \mathrm{p}=0.52)$

Some individual species' abundance did increase with proximity to water: Acadian flycatchers, Louisiana waterthrushes, wood thrushes, and hooded warblers. Murray and Stauffer (1995), working on dry oak sites in nearby Virginia, also found Acadian flycatchers and Louisiana waterthrushes associated with proximity to water. Dettmers and Bart (1999), working in Ohio, also associated Acadian flycatchers with stream bottoms and ravines.

In general, local (point) scale habitat attributes had little power in explaining bird abundances (Table 5-5). Relatively few variables (one-four depending on forest type) had significant effects on bird abundance, and in no case with a cumulative $\mathrm{r}^{2}$ greater than 0.07 . 


\section{Conservation Implications and Recommendations}

Results are in agreement with those of others who investigated bird-habitat relationships along streams in mostly forested landscapes (McGarigal and McComb 1992, Murray and Stauffer 1995, Darveau et al. 1995). Abundance and species richness on upland sites were equivalent to or greater than riparian ones. This also appears to be true at point, transect, and landscape scales.

In designing conservation strategies for the MNF landscape, therefore, forested stream zones do not appear to have exceptional values for forest songbirds as a group. I add, however, two caveats: 1) My scope was limited to forested, closed-canopy first- and second order-streams, and has no implications for other riparian/wetland types (such as broad alluvial zones, glades, or alder/willow thickets), where bird-habitat relationships are likely quite different; and 2) stream zones I studied still have special value in providing habitat for certain species, notably Acadian flycatcher, Louisiana waterthrush, wood thrush, and hooded warbler. Note all of these species are on the West Virginia Partners in Flight indicator species list. Note also, of course, that riparian zones provide many valuable ecosystem functions in addition to bird habitat. 


\section{Literature Cited}

Anthony, R.G., G.A. Green, E.D. Forsman, and S.K. Nelson. 1996. Avian abundance in riparian zones of three forest types in the Cascade Mountains, Oregon. Wilson Bull. 108(2):280-291.

Askins, R.A., J.F. Lynch, and R. Greenberg. 1990. Population declines in migratory birds in eastern North America. pp. 1-57 in Power, D.M. (ed.) Current ornithology: volume 7 New York: Plenum Press.

Beers, T.W., P.E. Dress, and L.C. Wensel. 1966. Aspect transformation in site productivity research. J.For. 64:691-692.

Brittingham, M. and S. Temple. 1983. Have cowbirds caused forest songbirds to decline? BioScience 33:31-35.

Core, E.L. 1966. Vegetation of West Virginia. Parsons, WV:McClain Printing Co., 217 pp.

Darveau, M., P. Beauchesne, L. Belanger, J. Huot, and P. Larue. 1995. Riparian forest strips as habitat for breeding birds in boreal forest. J. Wildl. Manage. 59(1):67-78.

Dawson, D.K., L.J. Darr, and C.S. Robbins. 1993. Predicting the distribution of breeding forest birds in a fragmented landscape. Trans. 58th N.A. Wildl. \& Natur. Resour. Conf., pp. 35-43.

Daubenmire, R. 1978. Plant geography: With special reference to North America. New York: Academic Press, 338 pp.

DeMeo, T.E. 1998. Terrestrial ecological classification of the Monongahela National Forest, West Virginia. Elkins, WV: USDA For. Serv. Unpub. Report on file.

Dettmers, R., and J. Bart. 1999. A GIS modeling method applied to predicting forest songbird habitat. Ecol. Appl. 9(1):152-163.

Donovan, T.M., R.H. Lamberson, A. Kimber, F.R. Thompson III, and J. Faaborg. 1995a. Modeling the effects of habitat fragmentation on source and sink demography of neotropical migrant birds. Conserv. Biol. 9(6):1396-1407.

Donovan, T.M., F.R. Thompson III, J. Faaborg, and J.R. Probst. 1995b. Reproductive success of migratory birds in habitat sources and sinks. Conserv. Biol 9:1380-1395.

Ferguson, D.E., P. Morgan, and F.D. Johnson, eds. 1989. Proceedings-Land classifications based on vegetation: Applications for resource management. Ogden, UT: USDA For. Serv. Gen. Tech. Rep. INT-257, 315 pp. 
Finch, D.M. 1991. Positive associations among riparian bird species correspond to elevational changes in plant communities. Can. J. Zool. 69:951-963.

Freemark, K., and B. Collins. 1992. Landscape ecology of birds breeding in temperate forest fragments. pp. 443-454 in J.M. Hagan III and D.W. Johnston, eds. Ecology and conservation of neotropical migrant landbirds. Washington, DC: Smithsonian Institution Press.

Freemark, K., J.B. Dunning, S.J. Hejl, and J.R. Probst. 1995. A landscape ecology perspective for research, conservation, and management. pp. 381-427 in T.E. Martin and D.M. Finch, eds. Ecology and management of Neotropical migratory birds. New York: Oxford Univ. Press.

Gates, J.E., and N.R. Giffen. 1991. Neotropical migrant birds and edge effects at a foreststream ecotone. Wilson Bull. 103(2):204-217.

Harris,L.D. 1984. The fragmented forest: Island biogeography theory and the preservation of biotic diversity. Chicago: Univ. of Chicago Press, 211 pp.

James, F.C., and H.H. Shugart, Jr. 1970. A quantitative method of habitat description. Audubon Field Notes 24(6):727-736. Wildl. Res. Unit, 27 pp.

Kachigan, S.K. 1986. Statistical analysis. New York: Radius Press, 589 pp.

Kessler, W.B., H. Salwasser, C.W. Cartwright, Jr., and J.A. Caplan. 1992. New perspectives for sustainable natural resources management. Ecol. Applic. 2:221-225.

Kuchler, A.W. 1964. Map and manual, potential natural vegetation of the coterminous United States. Amer. Geog. Soc. Special Publ. No. 36, 156 pp.

McCay, D.H., M.D.Abrams, and T.E. DeMeo. 1997. Gradient analysis of secondary forests of eastern West Virginia. J. Torrey Bot. Soc. 124(2):160-173.

McGarigal, K., and W.C. McComb. 1992. Streamside versus upslope breeding bird communities in the central Oregon Coast Range. J. Wildl. Manage. 56:10-23.

McGarigal, K. 1993. Relationship between landscape structure and avian abundance configurations in the Oregon Coast Range. Dissertation. Oregon State University, Corvallis.

McGarigal, K., and B.J. Marks. 1995. FRAGSTATS: spatial pattern analysis program for quantifying landscape structure. Gen. Tech. Rep. PNW-GTR-351. Portland, OR: USDA For. Serv., Pacific Northwest Research Station, 122 pp.

Murray, N.L., and D.F. Stauffer. 1995. Nongame bird use of habitat in Central Appalachian riparian forests. J. Wildl. Manage. 59(1):78-88. 
Noss, R.F. 1992. Issues of scale in conservation biology. pp. 239-250 in P.L. Fiedler and S.K. Jains, eds. Conservation biology: The theory and practice of nature conservation, preservation, and management. New York: Chapman and Hall.

Noss, R.F., and A.Y.Cooperrider. 1994. Saving nature's legacy. Washington, DC: Island Press, $416 \mathrm{pp}$.

Partners in Flight. 1998. Newsletter of the West Virginia Partners in Flight Working Group. Elkins, WV, Spring 1998.

Peterjohn, B.G., and J.R. Sauer. 1994. Population trends of woodland birds from the North American breeding bird survey.Wildl. Soc. Bull. 22:155-164.

Petersen, R.G. 1985. Design and analysis of experiments. New York: Marcel Dekker, 429 pp.

Ralph, C.J., G.R. Geupel, P. Pyle, T.E. Martin, and D.E. DeSante. 1993. Handbook of field methods for monitoring landbirds. Gen. Tech. Rep. PSW-GTR-144. Albany,CA: Pacific Southwest Res. Sta., USDA For. Serv.

Riitters, K.H., R.V. O'Neill, C.T. Hunsaker, J.D. Wickham, D.H. Yankee, S.P. Timmins, K.B. Jones, and B.L. Jackson. 1995. A factor analysis of landscape pattern and structure metrics. Landsc. Ecol. 10(1):23-39.

Robinson, S.K. 1992. Population dynamics of breeding neotropical migrants in a fragmented Illinois landscape. in J.M. Hagan III and D.W. Johnston, eds. Ecology and conservation of neotropical migrant landbirds. Washington, DC: Smithsonian Institution Press.

Robinson, S.K., F.R. Thompson III, T.M. Donovan, D.R. Whitehead, and J. Faaborg. 1995a. Regional effects of forest fragmentation on the nesting success of migratory birds. Science 267: 1987-1990.

Rosenberg, K.V., and J.V. Wells. 1995. Importance of geographic areas to neotropical migrant birds in the Northeast. Hadley, MA: USDI Fish and Wildl. Serv. Report, 120 pp.

SAS Institute. 1988. SAS/STAT user's guide. Cary, NC: Sas Institute, 1028 pp.

Simberloff, D. 1988. The contribution of population and community biology to conservation science. Ann. Rev. of Ecol. and Systematics 19:473-511.

Smith, C.R., D.M. Pence, and R.J. O'Connor. 1993. Status of Neotropical birds in the Northeast: A preliminary assessment. in Status and management of neotropical migratory birds. Fort Collins, CO: USDA For. Serv. Gen. Tech. Rep. RM-229, pp. 172-184. 
Soule, M.E., and D. Simberloff. 1986. What do genetics and ecology tell us about the design of nature reserves? Biol. Conserv. 35:19-40.

Temple, S.A., and J.R. Cary. 1988. Modeling dynamics of habitat-interior bird populations in fragmented landscapes. Conserv. Biol. 2(4):340-347.

Trimble. 1995. Trimble Explorer user's guide. Trimble Corp., Sunnyvale, CA.

Zar. 1984. Biostatistical analysis. Englewood Cliffs, NJ: Prentice-Hall. 
Table 5-1. Comparison of upland and riparian mean bird abundance and species richness by bird group, Monongahela National Forest, 1996-1997. Values followed by the same letter are not significantly different at $p=0.05$. $n=$ no. of points $X$ two years.

\begin{tabular}{|c|c|c|c|c|}
\hline \multirow[t]{2}{*}{ Bird Group } & \multicolumn{2}{|c|}{ Abundance } & \multicolumn{2}{|c|}{ Richness } \\
\hline & $\begin{array}{l}\text { Upland } \\
(\mathrm{n}=821)\end{array}$ & $\begin{array}{l}\text { Riparian } \\
(\mathrm{n}=255)\end{array}$ & $\begin{array}{l}\text { Upland } \\
(\mathrm{n}=823)\end{array}$ & $\begin{array}{l}\text { Riparian } \\
(\mathrm{n}=256)\end{array}$ \\
\hline Overall & $7.00 \mathrm{~A}$ & $5.97 \mathrm{~B}$ & $5.73 \mathrm{~A}$ & $5.02 \mathrm{~B}$ \\
\hline \multicolumn{5}{|l|}{ Nesting Guild } \\
\hline Ground & $1.77 \mathrm{~A}$ & $1.60 \mathrm{~A}$ & $1.46 \mathrm{~A}$ & $1.39 \mathrm{~A}$ \\
\hline High Canopy & $2.08 \mathrm{~A}$ & $1.85 \mathrm{~A}$ & $1.74 \mathrm{~A}$ & $1.59 \mathrm{~A}$ \\
\hline Low Canopy & $2.62 \mathrm{~A}$ & $2.57 \mathrm{~A}$ & $2.00 \mathrm{~A}$ & $2.05 \mathrm{~A}$ \\
\hline Shrub & $1.82 \mathrm{~A}$ & $1.61 \mathrm{~A}$ & $1.52 \mathrm{~A}$ & $1.35 \mathrm{~B}$ \\
\hline Cavity & $1.46 \mathrm{~A}$ & $1.52 \mathrm{~A}$ & $1.27 \mathrm{~A}$ & $1.33 \mathrm{~A}$ \\
\hline \multicolumn{5}{|l|}{ Migratory Guild } \\
\hline Short & $1.61 \mathrm{~A}$ & $1.39 \mathrm{~A}$ & $1.37 \mathrm{~A}$ & $1.25 \mathrm{~A}$ \\
\hline Neotropical & $5.42 \mathrm{~A}$ & $4.81 \mathrm{~A}$ & $4.35 \mathrm{~A}$ & $3.98 \mathrm{~A}$ \\
\hline Resident & $1.54 \mathrm{~A}$ & $1.74 \mathrm{~A}$ & $1.35 \mathrm{~A}$ & $1.48 \mathrm{~A}$ \\
\hline \multicolumn{5}{|l|}{ Foraging Guild } \\
\hline Ground & $2.01 \mathrm{~A}$ & $1.93 \mathrm{~A}$ & $1.68 \mathrm{~A}$ & $1.65 \mathrm{~A}$ \\
\hline Foliage & $1.27 \mathrm{~A}$ & $1.13 \mathrm{~A}$ & $1.05 \mathrm{~A}$ & $1.00 \mathrm{~A}$ \\
\hline Bark & $1.32 \mathrm{~A}$ & $1.31 \mathrm{~A}$ & $1.15 \mathrm{~A}$ & $1.13 \mathrm{~A}$ \\
\hline Mix & $3.13 \mathrm{~A}$ & $2.69 \mathrm{~B}$ & $2.45 \mathrm{~A}$ & $2.22 \mathrm{~A}$ \\
\hline \multicolumn{5}{|l|}{ Habitat Guild } \\
\hline Edge & $1.70 \mathrm{~A}$ & $1.44 \mathrm{~A}$ & $1.34 \mathrm{~A}$ & $1.20 \mathrm{~A}$ \\
\hline Interior/Edge & $2.56 \mathrm{~A}$ & $2.18 \mathrm{~B}$ & $1.98 \mathrm{~A}$ & 1.74B \\
\hline Forest Interior & $4.17 \mathrm{~A}$ & $3.95 \mathrm{~A}$ & $3.50 \mathrm{~A}$ & $3.39 \mathrm{~B}$ \\
\hline \multicolumn{3}{|l|}{ Species of Interest } & \multicolumn{2}{|c|}{ (Does not apply.) } \\
\hline Cerulean warbler & $0.07 \mathrm{~A}$ & $0.02 \mathrm{~B}$ & & \\
\hline $\begin{array}{c}\text { Worm-eating } \\
\text { warbler }\end{array}$ & $0.15 \mathrm{~A}$ & $0.15 \mathrm{~A}$ & & \\
\hline Red-eyed vireo & $0.86 \mathrm{~A}$ & $0.72 \mathrm{~A}$ & & \\
\hline Wood thrush & $0.13 \mathrm{~B}$ & $0.24 \mathrm{~A}$ & & \\
\hline Hooded warbler & $0.13 \mathrm{~B}$ & $0.24 \mathrm{~A}$ & & \\
\hline Acadian flycatcher & $0.15 \mathrm{~B}$ & $0.43 \mathrm{~A}$ & & \\
\hline $\begin{array}{l}\text { Louisiana } \\
\text { waterthrush }\end{array}$ & $0.02 \mathrm{~B}$ & $0.07 \mathrm{~A}$ & & \\
\hline Scarlet tanager & $0.28 \mathrm{~A}$ & $0.18 \mathrm{~B}$ & & \\
\hline $\begin{array}{l}\text { Eastern wood } \\
\text { peewee }\end{array}$ & $0.09 \mathrm{~A}$ & $0.07 \mathrm{~A}$ & & \\
\hline
\end{tabular}


Table 5-2. Comparison of upland and riparian mean bird abundance and species richness by forest type, Monongahela National Forest, 1996-1997. Values followed by the same letter are not significantly different at $p=0.05$. $n=$ no. of points $X$ two years.

\begin{tabular}{|l|l|l|l|l|}
\hline \multirow{2}{*}{ Forest Type } & \multicolumn{3}{|l|}{ Abundance } & Richness \\
\cline { 2 - 5 } & $\begin{array}{l}\text { Upland } \\
(\mathrm{n}=212)\end{array}$ & $\begin{array}{l}\text { Riparian } \\
(\mathrm{n}=60)\end{array}$ & $\begin{array}{l}\text { Upland } \\
(\mathrm{n}=212)\end{array}$ & $\begin{array}{l}\text { Riparian } \\
(\mathrm{n}=60)\end{array}$ \\
\hline Mixed Mesophytic & $8.99 \mathrm{~A}$ & $8.00 \mathrm{~B}$ & $7.00 \mathrm{~A}$ & $6.52 \mathrm{~A}$ \\
\hline Northern Hardwoods & $5.75 \mathrm{~A}$ & $4.51 \mathrm{~B}$ & $4.81 \mathrm{~A}$ & $3.69 \mathrm{~B}$ \\
\hline Red Spruce & $7.00 \mathrm{~A}$ & $5.69 \mathrm{~B}$ & $5.83 \mathrm{~A}$ & $4.89 \mathrm{~B}$ \\
\hline Dry Oaks & $6.17 \mathrm{~A}$ & $5.73 \mathrm{~A}$ & $5.23 \mathrm{~A}$ & $5.00 \mathrm{~A}$ \\
\hline \hline
\end{tabular}


Table 5-3. Significant distance distance to water (DTW) effects, transect scale, for the top ten species in each forest type. Only instances where $p=0.15$ are shown for site response variables. Negative DTW indicates the species were more abundant near water than farther away.

\begin{tabular}{|c|c|c|c|c|c|}
\hline Forest Type & Species & Variable & $\mathrm{p}$ & $\begin{array}{l}\text { Partial } \\
\mathrm{r} 2 \\
\end{array}$ & $\begin{array}{l}\text { Cum. } \\
\text { r2 }\end{array}$ \\
\hline \multirow{2}{*}{$\begin{array}{l}\text { Mixed } \\
\text { Mesophytic }\end{array}$} & Acadian flycatcher & -DTW & 0.03 & 0.04 & 0.04 \\
\hline & Red-eyed vireo & DTW & 0.07 & 0.02 & 0.02 \\
\hline Red Spruce & Dark-eyed junco & -DTW & 0.01 & 0.04 & 0.04 \\
\hline \multirow[t]{2}{*}{ Dry Oaks } & Eastern wood peewee & DTW & 0.08 & 0.08 & 0.08 \\
\hline & Red-eyed vireo & DTW & 0.07 & 0.03 & 0.03 \\
\hline $\begin{array}{l}\text { Northern } \\
\text { Hardwoods }\end{array}$ & (None) & & & & \\
\hline
\end{tabular}

Table 5-4. Significant distance to water effects, transect scale, for selected uncommon species abundance in each forest type. Analyses were performed using logistic regression. p values shown are the probability that the parameter estimate for the variable shown is greater than Wald's chisquare. Only instances where $\mathbf{p}=\mathbf{0 . 1 5}$ are shown for the response variables distance to water $(\mathrm{m})$ (=DTW). Negative DTW indicates the species were more abundant near water than farther away.

\begin{tabular}{|l|l|l|l|}
\hline \hline Forest Type & Species & Variable & $\mathrm{p}$ \\
\hline \hline $\begin{array}{l}\text { Mixed } \\
\text { Mesophytic }\end{array}$ & Cerulean warbler & DTW & 0.01 \\
\hline & Louisiana waterthrush & -DTW & 0.03 \\
\hline \hline Red Snruce & (None) & & \\
\hline \hline Dry Oaks & Cerulean warbler & DTW & 0.00 \\
\hline & Hooded warbler & -DTW & 0.02 \\
\hline \hline $\begin{array}{l}\text { Northern } \\
\text { Hardwoods }\end{array}$ & Yellow-billed cuckoo & DTW & 0.01 \\
\hline \hline
\end{tabular}


Table 5-5. Habitat variables significantly $(\mathbf{p}<0.05)$ associated with overall bird abundance, comparison of upland and riparian zones, by forest type. Monongahela National Forest, 1996-1997 seasons. A negative sign indicates negative association with the variable; e.g., "._" for elevation means more birds were found at lower elevation.

\begin{tabular}{|c|c|c|c|c|}
\hline \multirow[t]{2}{*}{ Habitat Variable } & \multicolumn{2}{|c|}{ Upland Model } & \multicolumn{2}{|c|}{ Riparian Model } \\
\hline & $\mathrm{p}$ & Partial r2 & $\mathrm{p}$ & Partial r2 \\
\hline \multicolumn{5}{|l|}{ Mixed Mesophytic } \\
\hline Elevation & 0.0001 & -0.02 & 0.03 & -0.02 \\
\hline Rhododendron Cover & 0.0001 & -0.01 & & \\
\hline Canopy Layer 1 & & & 0.03 & -0.01 \\
\hline \multicolumn{5}{|c|}{ Northern Hardwoods } \\
\hline Sum of Conifer Cover & 0.01 & -0.01 & & \\
\hline Stand Height & 0.02 & +0.01 & & \\
\hline Canopy Layer 2 & & & 0.02 & -0.06 \\
\hline Canopy Layer 6 & & & 0.01 & -0.01 \\
\hline \multicolumn{5}{|l|}{ Red Spruce } \\
\hline Slope & 0.02 & -0.01 & & \\
\hline \multirow[t]{2}{*}{ Canopy Layer 4} & 0.02 & +0.01 & & \\
\hline & & & (None) & \\
\hline \multicolumn{5}{|l|}{ Dry Oaks } \\
\hline \multirow[t]{2}{*}{ Elevation } & 0.01 & -0.01 & & \\
\hline & & & (None) & \\
\hline
\end{tabular}


Table 5-6. Habitat variables differing significantly between upland and riparian sites by forest type, Monongahela National Forest, 1996-1997. Variables in bold are those significantly related to overall bird abundance. Note few variables are related to bird abundance.

\begin{tabular}{|l|l|l|l|l|l|}
\hline Variable & Upland Mean & $\mathrm{n}$ & Riparian Mean & $\mathrm{n}$ & $\mathrm{p}$ \\
\hline Overall & & & & & \\
\hline Slope (\%) & 27.5 & 413 & 20.4 & 130 & 0.002 \\
\hline Elevation (m) & 984 & 410 & 905 & 130 & 0.0004 \\
\hline CAN5 (\%) & 46.5 & 413 & 57.5 & 130 & 0.0002 \\
\hline Mixed Mesophytic & & & & & \\
\hline Slope (\%) & 33.6 & 108 & 26.1 & 30 & 0.04 \\
\hline Elevation (m) & 820 & 108 & 711 & 30 & 0.0000 \\
\hline OSCON (\%) & 0.7 & 108 & 4.0 & 30 & 0.03 \\
\hline SUMCON (\%) & 4.0 & 108 & 12.1 & 30 & 0.02 \\
\hline SDIALL & 56.2 & 108 & 64.5 & 30 & 0.003 \\
\hline CAN2 (\%) & 40.5 & 108 & 52.0 & 30 & 0.01 \\
\hline CAN3 (\%) & 50.0 & 108 & 61.5 & 30 & 0.007 \\
\hline CAN4 (\%) & 53.0 & 108 & 66.0 & 30 & 0.006 \\
\hline Northern Hardwoods & & & & & \\
\hline CAN1 (\%) & 8.2 & 103 & 5.7 & 29 & 0.007 \\
\hline CAN2 (\%) & 9.1 & 103 & 4.3 & 28 & 0.0000 \\
\hline CAN3 (\%) & 9.9 & 103 & 7.1 & 29 & 0.004 \\
\hline RHMA (\%) & 3.6 & 103 & 22.8 & 29 & 0.0000 \\
\hline CAN6(\%) & 31.0 & 103 & 50.0 & 29 & 0.01 \\
\hline Red Spruce & & & & & \\
\hline Elevation (m) & 1259 & 103 & 1149 & 38 & 0.0000 \\
\hline Standht (m) & 20.7 & 103 & 22.9 & 37 & 0.047 \\
\hline SDIALL & 46.3 & 102 & 55.8 & 38 & 0.0003 \\
\hline CAN5 (\%) & 35.5 & 102 & 61.5 & 38 & 0.0000 \\
\hline CAN6 (\%) & 11.0 & 102 & 28.0 & 38 & 0.001 \\
\hline Dry Oaks & & & & & \\
\hline Slope (\%) & 41.0 & 99 & 17.9 & 33 & 0.0000 \\
\hline Elevation (m) & 779 & 100 & 718 & 33 & 0.02 \\
\hline CAN3 (\%) & 52.3 & 100 & 44.0 & 33 & 0.04 \\
\hline OSCON (\%) & 9.6 & 100 & 22.6 & 33 & 0.004 \\
\hline SUMCON (\%) & 19.2 & 100 & 35.6 & 33 & 0.006 \\
\hline \hline
\end{tabular}


Table A-1. List of bird study areas, Monongahela National Forest, West Virginia, 1996-1997. Each study area encompasses a $5 \mathrm{~km} \mathrm{X} 5 \mathrm{~km}$ square and includes four transects. Typically each transect has 11 point count stations, each $250 \mathrm{~m}$ from the next, although the number of stations varies. Of each set of four transects in a study area, one is riparian (along a first- or second-order stream), and three are upland.

\begin{tabular}{|c|c|c|c|}
\hline Forest Type & Study Area & Transect & Points (Total No. Points ) \\
\hline \multirow[t]{4}{*}{ Mixed Mesophytic } & Location & 1 & $0-9(10)$ \\
\hline & & 2 & $0-17(18)$ \\
\hline & & 3 & $0-8(9)$ \\
\hline & & 4 & $0-7(8)$ \\
\hline \multirow[t]{4}{*}{ Mixed Mesophytic } & Otter Creek & $\overline{5}$ & $0-13(14)$ \\
\hline & & 6 & $0-10(11)$ \\
\hline & & 7 & $0-9(10)$ \\
\hline & & 8 & $0-10(11)$ \\
\hline \multirow[t]{4}{*}{ Northern Hardwoods } & Whitmer & 17 & $0-6(7)$ \\
\hline & & 18 & $0-14(15)$ \\
\hline & & 19 & $0-10(11)$ \\
\hline & & 20 & $0-10(11)$ \\
\hline \multirow[t]{4}{*}{ Northern Hardwoods } & Cranberry & 21 & $0-10(11)$ \\
\hline & & 22 & $0-10(11)$ \\
\hline & & 23 & $0-10(11)$ \\
\hline & & 24 & $0-10(11)$ \\
\hline \multirow[t]{4}{*}{ Red Spruce } & Tea Creek & 29 & (0-15 (16) \\
\hline & & 30 & $0-8(9)$ \\
\hline & & 31 & $0-11(12)$ \\
\hline & & 32 & $0-11(12)$ \\
\hline \multirow[t]{4}{*}{ Dry Oaks } & North Fork Mountain & 33 & $0-9(10)$ \\
\hline & & 34 & $0-10$ \\
\hline & & 35 & $0-10(11)$ \\
\hline & & 36 & $0-10(11)$ \\
\hline \multirow[t]{4}{*}{ Red Spruce } & Cheat Bridge & 37 & $0-10(11)$ \\
\hline & & 38 & $0-10(11)$ \\
\hline & & 39 & $0-10(11)$ \\
\hline & & 40 & $0-10(11)$ \\
\hline \multirow[t]{4}{*}{ Mixed Mesophytic } & Chestnut Ridge & 41 & $0-10(11)$ \\
\hline & & 42 & $0-3,5-11(11)$ \\
\hline & & 43 & $0-10(11)$ \\
\hline & & 44 & $0-8(9)$ \\
\hline \multirow[t]{4}{*}{ Dry Oaks } & Middle Mountain South & 45 & $0-10(11)$ \\
\hline & & 46 & $0-10(11)$ \\
\hline & & 47 & $0-10(11)$ \\
\hline & & 48 & $0-10(11)$ \\
\hline \multirow[t]{4}{*}{ Dry Oaks } & Minnehaha Springs & 49 & $0-10(11)$ \\
\hline & & 50 & $0-10(11)$ \\
\hline & & 51 & $0-10(11)$ \\
\hline & & 52 & $0-10(11)$ \\
\hline \multirow[t]{4}{*}{ Northern Hardwoods } & Falls of Hills Creek & 53 & $0-10(11)$ \\
\hline & & 54 & $0-10(11)$ \\
\hline & & 55 & $0-10(11)$ \\
\hline & & 56 & $0-10(11)$ \\
\hline \multirow[t]{3}{*}{ Red Spruce } & Gauley Mountain & $\begin{array}{l}57 \\
58\end{array}$ & $\begin{array}{l}0-10(11) \\
0-13(14)\end{array}$ \\
\hline & & 59 & $0-10(11)$ \\
\hline & & 60 & $0-10(11)$ \\
\hline
\end{tabular}


Table A-2, Class variables used in the analyses of variance, point count data set, Monongahela National Forest bird study, 1996-1997. Block refers to the $25 \mathbf{k m}^{2}$ study areas, with three study areas per forest type. Years sampled were 1996 and 1997. Points were typically numbered 0 to 11, but a few (6 of 48) varied from this amont, with one transect as low as seven points, and one as great as 18. Transects were always numbered 1-4 per study area (block), with three upland and one riparian. Riparian status is 1 for upland and 2 for riparian. Total number of observations $=1079$ (=No. transects $(4) \mathrm{X}$ no. points/transect $(11+/-) \mathrm{X}$ no. of blocks (3) $\mathrm{X}$ no. of forest types (4) X 2 years sampling). For forest types, MMES=Mixed Mesophytic, NHWDS=Northern Hardwoods, SPRUCE=Red Spruce, and XOAKS= Dry (xeric) oaks.

\begin{tabular}{|l|c|l|}
\hline \hline Class & Levels & Values \\
\hline \hline BLOCK & 3 & 123 \\
\hline YEAR & 2 & 19961997 \\
\hline POINT & 18 & 01234567891011121314151617 \\
\hline TRANSECT & 12 & 123456789101112 \\
\hline RIPARIAN & 2 & $12 \quad(1=$ Upland 2 = Riparian $)$ \\
\hline $\begin{array}{l}\text { FOREST } \\
\text { TYPE }\end{array}$ & 4 & MMES NHWDS SPRUCE XOAKS \\
\hline \hline
\end{tabular}


Table A-3. Ten most abundant species for each forest type. Count is the sum of point abundances for the 1996 and 1997 seasons.

\begin{tabular}{|l|c||l|c|}
\hline \multicolumn{2}{|l||}{ Mixed Mesophytic } & Northern Hardwoods \\
\hline \hline Species & Count & Species & Count \\
\hline Red-eyed vireo & 386 & Red-eyed vireo & 223 \\
\hline Black-throated green warbler & 159 & Black-throated green warbler & 175 \\
\hline American redstart & 147 & Dark-eyed junco & 113 \\
\hline Acadian flycatcher & 136 & Black-throated blue warbler & 91 \\
\hline Scarlet tanager & 133 & Solitary vireo & 81 \\
\hline Black and white warbler & 105 & Blackburnian warbler & 77 \\
\hline Wood thrush & 103 & Magnolia warbler & 72 \\
\hline Rose-breasted grosbeak & 89 & Veery & 64 \\
\hline Solitary vireo & 82 & Winter wren & 62 \\
\hline Veery & 79 & Black-capped chickadee & 47 \\
\hline \hline Dry Oaks & & Red Spruce & Count \\
\hline \hline Species & Count & Species & 212 \\
\hline Red-eyed vireo & 170 & Black-throated green warbler & 201 \\
\hline Ovenbird & 146 & Dark-eyed junco & 171 \\
\hline Worm-eating warbler & 134 & Solitary vireo & 153 \\
\hline Black and white warbler & 101 & Magnolia warbler & 120 \\
\hline Scarlet tanager & 100 & Golden-crowned kinglet & 113 \\
\hline Acadian flycatcher & 86 & Red-eyed vireo & 105 \\
\hline Black-throated green warbler & 63 & Winter wren & 94 \\
\hline Eastern wood peewee & 47 & Blackburnian warbler & \\
\hline Solitary vireo & 32 & Black-throated blue warbler & \\
\hline $\begin{array}{l}\text { Blue-gray gnatcatcher } \\
\text { White-breasted nuthatch }\end{array}$ & 25 & Black-capped chickadee & \\
\hline \hline & & & \\
\hline
\end{tabular}


Table A-4. Analysis methods and variables analyzed at the three study scales on the Monongahela National Forest, West Virginia, 1996-1997. See text for further discussion.

\begin{tabular}{|l|l|l|l|l|l|}
\hline \hline Scale & $\begin{array}{l}\text { Abundance and } \\
\text { Species } \\
\text { Richness } \\
\text { Method }\end{array}$ & $\begin{array}{l}\text { Survival } \\
\text { Analysis } \\
\text { Method }\end{array}$ & $\begin{array}{l}\text { Clutch Size Response } \\
\text { Analysis Method }\end{array}$ & $\begin{array}{l}\text { Local Habitat } \\
\text { Variables }\end{array}$ & $\begin{array}{l}\text { Landscape } \\
\text { Variables }\end{array}$ \\
\hline $\begin{array}{l}\text { Study Area } \\
(5 \mathrm{~km} \text { X } 5 \mathrm{~km})\end{array}$ & $\begin{array}{l}\text { Analysis of } \\
\text { variance and } \\
\text { means } \\
\text { comparisons }\end{array}$ & $\begin{array}{l}\text { CONTRAST } \\
\text { program }\end{array}$ & Analysis of Variance & N/A & Core area, edge density \\
\hline $\begin{array}{l}\text { Nest Search Plot } \\
(200 \mathrm{~m} \text { X 2000 m, } \\
\text { two per study area })\end{array}$ & $\begin{array}{l}\text { Analysis of } \\
\text { variance and } \\
\text { means } \\
\text { comparisons }\end{array}$ & $\begin{array}{l}\text { CONTRAST } \\
\text { program }\end{array}$ & Analysis of Variance & N/A & Core area, edge density \\
\hline $\begin{array}{l}\text { Nest Search Plot } \\
(200 \mathrm{~m} \text { X 2000 m, } \\
\text { two per study area })\end{array}$ & \begin{tabular}{l} 
(Same) \\
\hline $\begin{array}{l}\text { Individual Nest } \\
\text { (Many per nest } \\
\text { search plot })\end{array}$
\end{tabular} & $\begin{array}{l}\text { Logistic } \\
\text { Negression }\end{array}$ & Stepwise regression & N/A & $\begin{array}{l}\text { Core area, edge density, distance to } \\
\text { edge, distance to water }\end{array}$ \\
\hline \hline
\end{tabular}


Table A-5. Weights used for the edge types encountered on the Monongahela National Forest bird study, 1996-1997. Lower weights mean the distance to edge is decreased in statistical analyses. Weights were developed using nest survival data from a companion study (Chapter 3). Nest survival from 0-25 $\mathrm{m}$ from edges was used because survival rates at greater distances was statistically equivalent (26-50 $\mathrm{m}$ ) or ambiguous (beyond $50 \mathrm{~m}$ ).

\begin{tabular}{|l|c|c|c|}
\hline Edge Type & Weight & $\begin{array}{c}\text { Nest Survival, 0-25 m } \\
\text { From Edge }\end{array}$ & No. Nests \\
\hline \hline Paved Road & 0.7 & Insuf. Data & \\
\hline Open Canopy Road & 0.7 & 0.29 & 43 \\
\hline Partially Open Canopy Road & 0.5 & 0.21 & 53 \\
\hline Agricultural Field & 0.5 & Insuf. Data & \\
\hline Development (Houses, etc.) & 0.5 & Insuf. Data & \\
\hline Regenerating Clearcut & 1.00 & 0.41 & 49 \\
\hline Wildlife Opening & 0.5 & 0.25 & 14 \\
\hline Natural Forest Gap & 0.5 & 0.18 & 11 \\
\hline \hline
\end{tabular}


Appendix Table A-6. Comparison of forest types, environmental and forest structural data, Monongahela National Forest bird study, 1996-1997. Variables in bold show significant $(\mathbf{p}<0.05)$ differences between the forest types.

\begin{tabular}{|c|c|c|c|c|}
\hline Variable & Mixed Mesophytic & $\begin{array}{l}\text { Northern } \\
\text { Hardwoods }\end{array}$ & Red Spruce & Dry Oaks \\
\hline & Mean/SE/n & Mean/SE/n & Mean/SE/n & Mean/SE/n \\
\hline Slope (\%) & 32.0/1.52/138 & 18.1/1.11/132 & 18.0/1.26/141 & 35.2/1.89/132 \\
\hline Aspect (Transformed) & $0.92 / 0.06 / 138$ & $1.01 / 0.06 / 119$ & $1.01 / 0.06 / 141$ & $1.01 / 0.06 / 133$ \\
\hline Elevation (ft) & 2612/36.6/138 & $\mathbf{3 5 0 0 / 3 0 . 8 / 1 2 8}$ & 4030/24.3/141 & 2503/37.9/133 \\
\hline Distance to Water (m) & $329 / 39 / 138$ & $388 / 48 / 132$ & $443 / 46 / 141$ & $449 / 52 / 133$ \\
\hline $\begin{array}{l}\text { Sum of Conifer } \\
\text { Cover }(\%)\end{array}$ & $\mathbf{5 . 8 / 1 . 5 / 1 3 8}$ & 19.4/2.3/132 & 38.7/3.1/141 & 23.3/2.6/133 \\
\hline $\begin{array}{l}\text { Overstory Conifer Cover } \\
(\%)\end{array}$ & $1.4 / 0.6 / 138$ & 6.6/1.4/131 & $\mathbf{1 8 . 3 / 2 . 0 / 1 4 1}$ & 12.8/2.0/133 \\
\hline $\begin{array}{l}\text { Understory Conifer Cover } \\
(\%)\end{array}$ & 4.4/1.1/138 & 12.8/1.5/132 & 20.4/1.9/141 & $10.9 / 1.4 / 133$ \\
\hline $\begin{array}{l}\text { Rhododendron } \\
\text { Cover }(\%)\end{array}$ & 3.50/1.25/138 & 7.82/1.69/132 & 3.69/1.33/141 & 2.21/0.82/124 \\
\hline Stand Height $(\mathrm{m})$ & 26.7/0.5/138 & 22.8/0.5/132 & 21.3/0.5/140 & 21.6/0.5/133 \\
\hline $\begin{array}{l}\text { Structural Diversity Index } \\
\text { (SDIALL) }\end{array}$ & 58.0/1.18/138 & 53.4/1.28/132 & 48.9/1.18/140 & 48.1/1.09/133 \\
\hline $\begin{array}{l}\text { Canopy Layer 1, } \\
0.5 \text { m-3 m (\%) }\end{array}$ & 6.62/0.38/138 & 7.64/0.39/132 & 6.89/0.35/140 & $\mathbf{5 . 6 1 / 0 . 3 1 / 1 3 3}$ \\
\hline $\begin{array}{l}\text { Canopy Layer } 2 \text {, } \\
3 \text { m-6 m (\%) }\end{array}$ & $8.62 / 0.38 / 138$ & $8.05 / 0.40 / 131$ & $8.09 / 0.40 / 140$ & $8.17 / 0.34 / 133$ \\
\hline $\begin{array}{l}\text { Canopy Layer } 3 \text {, } \\
6 \mathrm{~m}-12 \mathrm{~m}(\%)\end{array}$ & $10.5 / 0.35 / 138$ & $9.33 / 0.41 / 132$ & $10.5 / 0.38 / 140$ & $10.1 / 0.34 / 133$ \\
\hline $\begin{array}{l}\text { Canopy Layer } 4, \\
12 \mathrm{~m}-18 \mathrm{~m}(\%)\end{array}$ & $11.2 / 0.39 / 138$ & $10.7 / 0.44 / 132$ & $11.7 / 0.44 / 140$ & $10.1 / 0.42 / 133$ \\
\hline $\begin{array}{l}\text { Canopy Layer 5, } \\
18 \text { m-24 m (\%) }\end{array}$ & 11.5/0.44/138 & 10.7/0.53/132 & 8.51/0.52/140 & 8.76/0.52/133 \\
\hline $\begin{array}{l}\text { Canopy Layer 6, } \\
>24 \mathrm{~m}(\%)\end{array}$ & $\mathbf{9 . 5 7 / 0 . 5 9 / 1 3 8}$ & $7.03 / 0.62 / 132$ & 3.15/0.46/140 & $\mathbf{5 . 4 0 / 0 . 5 6 / 1 3 3}$ \\
\hline
\end{tabular}


Table A-7. Bird species and counts used in logistic regression analyses. Count represents the sum of point abundances for the 1996 and 1997 seasons, at 132 points per forest type per year.

\begin{tabular}{|l|l|c|}
\hline Forest Tvpe & Species & Count \\
\hline \hline Mixed Mesophytic & Cerulean warbler & 30 \\
\hline & Brown-headed cowbird & 19 \\
\hline & Louisiana waterthrush & 18 \\
\hline Northern Hardwoods & Hooded warbler & 14 \\
\hline & Brown-headed cowbird & 6 \\
\hline \hline Dry Oaks & Louisiana waterthrush & 6 \\
\hline & Brown-headed cowbird & 22 \\
\hline & Hooded warbler & 11 \\
\hline & Cerulean warbler & 10 \\
\hline & Louisiana waterthrush & 8 \\
\hline Red Spruce & Yellow-billed cuckoo & 5 \\
\hline & Hooded warbler & 6 \\
\hline
\end{tabular}


Table A-8. Principal component factor loadings with eigenvalues greater than 1.00 by habitat variable, transect scale. Values are presented by transect for the four major forest types, Monongahela National Forest, 1996-1997. Components were rotated to clarify differences between variables. Values in bold indicate variables used in subsequent multiple regressions. Final communalities are the percentage of variation in the original variable retained by the rotated factor loading (Jackson 1993).

\begin{tabular}{|c|c|c|c|c|c|}
\hline Variable & PC I & PC II & PC III & PC IV & \\
\hline \multicolumn{6}{|c|}{ Mixed Mesophytic Transects } \\
\hline Eigenvalue & 4.04 & 2.87 & 1.81 & 1.47 & \multirow{3}{*}{$\begin{array}{l}\text { Final } \\
\text { Communalities }\end{array}$} \\
\hline Percent & 33.7 & 23.9 & 15.0 & 12.2 & \\
\hline Cum Percent & 33.7 & 57.6 & 72.7 & 84.9 & \\
\hline Slope & 0.021 & 0.243 & -0.828 & -0.351 & 0.87 \\
\hline AspectT & 0.023 & 0.319 & 0.890 & -0.170 & 0.92 \\
\hline Elev & 0.115 & -0.108 & -0.003 & $\mathbf{0 . 8 8 4}$ & 0.81 \\
\hline Oscon & -0.241 & 0.670 & -0.086 & -0.523 & 0.79 \\
\hline Sumcon & -0.167 & 0.742 & -0.430 & -0.407 & 0.93 \\
\hline Standht & 0.764 & -0.251 & 0.021 & 0.390 & 0.80 \\
\hline Distwatr & -0.126 & -0.834 & -0.123 & 0.065 & 0.73 \\
\hline RHMA & 0.054 & 0.225 & -0.806 & 0.135 & 0.72 \\
\hline SDIALL & -0.319 & 0.818 & -0.220 & 0.303 & 0.91 \\
\hline CAN1 & -0.903 & -0.131 & -0.028 & -0.155 & 0.86 \\
\hline CAN2 & -0.908 & 0.331 & 0.038 & 0.131 & 0.95 \\
\hline CAN6 & 0.587 & 0.290 & -0.338 & 0.599 & 0.90 \\
\hline \multicolumn{6}{|c|}{ Northern Hardwood Transects } \\
\hline Eigenvalue & 3.98 & 2.73 & 2.42 & 1.55 & \multirow{3}{*}{$\begin{array}{l}\text { Final } \\
\text { Communalities }\end{array}$} \\
\hline Percent & 30.6 & 21.0 & 18.6 & 12.0 & \\
\hline Cum Percent & 30.6 & 51.6 & 70.3 & 82.2 & \\
\hline Slope & -0.165 & 0.446 & 0.009 & 0.694 & 0.71 \\
\hline AspectT & 0.066 & 0.728 & 0.194 & 0.319 & 0.67 \\
\hline Elev & 0.015 & -0.678 & 0.603 & -0.015 & 0.82 \\
\hline Sumcon & 0.208 & -0.910 & 0.148 & -0.062 & 0.90 \\
\hline Standht & 0.215 & -0.134 & -0.890 & 0.057 & 0.86 \\
\hline Distwatr & 0.009 & -0.443 & 0.038 & 0.791 & 0.82 \\
\hline RHMA & 0.065 & -0.240 & 0.061 & -0.799 & 0.70 \\
\hline SDIALL & -0.740 & -0.432 & -0.416 & 0.021 & 0.91 \\
\hline CAN1 & -0.386 & -0.808 & -0.067 & -0.018 & 0.81 \\
\hline CAN2 & -0.525 & -0.55 & 0.439 & 0.177 & 0.81 \\
\hline CAN3 & -0.818 & -0.109 & 0.501 & 0.152 & 0.95 \\
\hline CAN4 & -0.901 & 0.182 & -0.040 & 0.040 & 0.85 \\
\hline CAN5 & -0.157 & 0.090 & -0.916 & -0.010 & 0.87 \\
\hline
\end{tabular}


Table A-8 (Continued). Principal component factor loadings with eigenvalues greater than 1.00 by habitat variable, transect scale. Values are presented by transect for the four major forest types, Monongahela National Forest, 1996-1997. Components were rotated to clarify differences between variables. Values in bold indicate variables used in subsequent multiple regressions. Final communalities are the percentage of variation in the original variable retained by the rotated factor loading (Jackson 1993).

\begin{tabular}{|c|c|c|c|c|c|}
\hline Variable & PC I & $\overline{\mathrm{PC} \text { II }}$ & PC III & PC IV & \\
\hline \multicolumn{6}{|c|}{ Red Spruce Transects } \\
\hline Eigenvalue & 3.77 & 3.38 & 1.91 & 1.56 & \multirow{3}{*}{$\begin{array}{l}\text { Final } \\
\text { Communalities }\end{array}$} \\
\hline Percent & 29.0 & 26.0 & 14.7 & 12.0 & \\
\hline Cum Percent & 29.0 & 55.1 & 69.8 & 81.7 & \\
\hline Slope & 0.661 & 0.154 & -0.131 & -0.232 & 0.53 \\
\hline AspectT & -0.307 & -0.048 & 0.690 & 0.133 & 0.59 \\
\hline Elev & -0.670 & -0.449 & -0.404 & -0.167 & 0.84 \\
\hline Sumcon & -0.80 & 0.289 & 0.134 & -0.405 & 0.91 \\
\hline Standht & -0.065 & 0.639 & 0.418 & -0.527 & 0.96 \\
\hline Distwatr & -0.135 & -0.741 & 0.404 & 0.258 & 0.78 \\
\hline RHMA & 0.280 & 0.007 & -0.873 & 0.079 & 0.79 \\
\hline SDIALL & 0.133 & 0.883 & -0.042 & 0.287 & 0.94 \\
\hline CAN1 & -0.409 & -0.155 & 0.117 & 0.863 & 0.80 \\
\hline CAN2 & 0.342 & -0.00 & -0.217 & 0.846 & 0.93 \\
\hline CAN3 & 0.342 & -.050 & -0.736 & 0.463 & 0.87 \\
\hline CAN4 & 0.705 & 0.334 & -0.315 & -0.108 & 0.72 \\
\hline CAN5 & 0.123 & 0.910 & 0.148 & -0.312 & 0.96 \\
\hline \multicolumn{6}{|c|}{ Dry Oak Transects } \\
\hline Eigenvalue & 3.35 & 2.78 & 2.10 & $(<1.00)$ & \multirow{3}{*}{$\begin{array}{l}\text { Final } \\
\text { Communalities }\end{array}$} \\
\hline Percent & 30.4 & 25.2 & 19.1 & & \\
\hline Cum Percent & 30.4 & 55.7 & 74.7 & & \\
\hline Slope & 0.583 & 0.400 & -0.565 & & 0.82 \\
\hline AspectT & 0.704 & -0.268 & 0.042 & & 0.57 \\
\hline Elev & 0.800 & 0.141 & 0.277 & & 0.73 \\
\hline Uscon & 0.434 & -0.075 & 0.800 & & 0.83 \\
\hline Sumcon & 0.070 & -0.382 & 0.888 & & 0.94 \\
\hline Standht & -0.091 & 0.950 & -0.099 & & 0.92 \\
\hline Distwatr & 0.073 & -0.512 & -0.738 & & 0.81 \\
\hline RHMA & 0.522 & 0.511 & -0.150 & & 0.56 \\
\hline SDIALL & 0.183 & -0.858 & 0.048 & & 0.77 \\
\hline CAN1 & -0.819 & 0.248 & 0.093 & & 0.74 \\
\hline CAN2 & -0.710 & 0.027 & -0.154 & & 0.53 \\
\hline
\end{tabular}


Table A-9. Principal component factor loadings with eigenvalues greater than 1.00 by habitat variable, point scale. Values are presented for the four major forest types, Monongahela National Forest, 1996-1997. Values in bold indicate variables used in subsequent multiple regressions.

\begin{tabular}{|c|c|c|c|c|}
\hline Variable & PC I & PC II & PC III & PC IV \\
\hline \multicolumn{5}{|c|}{ Mixed Mesophytic Points } \\
\hline Eigenvalue & 3.330 & 2.667 & 1.98 & 1.67 \\
\hline Percent & 17.5 & 14.0 & 10.4 & 8.78 \\
\hline Cum Percent & 17.5 & 31.5 & 41.9 & 50.7 \\
\hline Slope & 0.24 & -0.05 & 0.06 & -0.25 \\
\hline Aspect & 0.07 & -0.01 & -0.19 & 0.04 \\
\hline Elevation & -0.18 & 0.16 & 0.25 & 0.02 \\
\hline US Conifer & 0.38 & -0.15 & -0.22 & -0.02 \\
\hline OS Conifer & 0.33 & -0.05 & -0.24 & -0.24 \\
\hline Sum Conifer & 0.43 & -0.13 & -0.27 & -0.13 \\
\hline WDTE & 0.17 & 0.06 & 0.12 & -0.03 \\
\hline Height & -0.02 & $\mathbf{0 . 4 3}$ & -0.08 & 0.29 \\
\hline Dist to Water & -0.18 & 0.07 & 0.32 & -0.32 \\
\hline Rhododendron & -0.14 & -0.10 & -0.14 & 0.34 \\
\hline SDIAll & $\mathbf{0 . 3 8}$ & 0.19 & 0.31 & 0.32 \\
\hline CAN1 & 0.05 & -0.37 & 0.20 & 0.37 \\
\hline CAN2 & 0.19 & -0.30 & 0.26 & 0.36 \\
\hline CAN3 & 0.21 & -0.17 & 0.37 & 0.02 \\
\hline CAN4 & 0.27 & 0.17 & 0.21 & -0.13 \\
\hline CAN5 & 0.26 & 0.43 & -0.02 & -0.02 \\
\hline CAN6 & 0.12 & 0.47 & -0.005 & 0.22 \\
\hline \multicolumn{5}{|c|}{ Northern Hardwood Points } \\
\hline Eigenvalue & 3.36 & 2.94 & 2.17 & 1.53 \\
\hline Percent & 18.7 & 16.3 & 12.03 & 8.49 \\
\hline Cum Percent & 18.7 & 35.0 & 47.0 & 55.5 \\
\hline Slope & -0.01 & 0.05 & -0.18 & 0.31 \\
\hline Aspect & -0.18 & -0.09 & -0.27 & -0.14 \\
\hline Elevation & 0.27 & 0.05 & 0.03 & 0.15 \\
\hline US Conifer & 0.31 & 0.16 & 0.37 & 0.10 \\
\hline OS Conifer & 0.31 & -0.05 & $\mathbf{0 . 3 0}$ & 0.21 \\
\hline Sum Conifer & 0.39 & 0.08 & 0.42 & -0.12 \\
\hline WDTE & -0.13 & 0.21 & 0.24 & -0.19 \\
\hline Height & -0.28 & 0.36 & 0.19 & -0.43 \\
\hline Dist to Water & 0.22 & -0.13 & -0.14 & -0.13 \\
\hline Rhododendron & 0.07 & 0.16 & 0.16 & 0.13 \\
\hline SDIALL & 0.07 & 0.52 & -0.15 & 0.10 \\
\hline CAN1 & 0.19 & 0.20 & -0.03 & 0.50 \\
\hline CAN2 & 0.30 & 0.01 & -0.15 & 0.47 \\
\hline CAN3 & 0.29 & 0.12 & -0.33 & -0.19 \\
\hline CAN4 & 0.11 & 0.34 & -0.23 & -0.43 \\
\hline CAN5 & -0.15 & 0.47 & -0.06 & -0.13 \\
\hline CAN6 & -0.30 & 0.26 & 0.24 & 0.13 \\
\hline
\end{tabular}


Table A-9 (Continued). Factor loadings by habitat variable for principal components axes, point scale. Values are presented for the four major forest types, Monongahela National Forest bird point counts, 1996-1997. Values in bold indicate variables used in subsequent multiple regressions.

\begin{tabular}{|c|c|c|c|c|}
\hline Variable & PC I & PC II & PC III & PC IV \\
\hline \multicolumn{5}{|c|}{ Red Spruce Points } \\
\hline Eigenvalue & 3.43 & 3.30 & 2.16 & 1.35 \\
\hline Percent & 20.2 & 19.4 & 12.7 & 7.95 \\
\hline Cum Percent & 20.2 & 39.6 & 52.3 & 60.2 \\
\hline Slope & -0.13 & 0.18 & -0.13 & 0.19 \\
\hline Aspect & 0.03 & -0.03 & -0.005 & 0.57 \\
\hline Elevation & 0.25 & -0.25 & 0.09 & -0.16 \\
\hline US Conifer & 0.28 & 0.17 & 0.32 & 0.36 \\
\hline OS Conifer & 0.42 & -0.04 & 0.09 & -0.04 \\
\hline Sum Conifer & 0.44 & 0.07 & 0.25 & 0.19 \\
\hline WDTE & 0.09 & 0.09 & -0.08 & -0.43 \\
\hline Height & 0.17 & $\mathbf{0 . 4 3}$ & 0.15 & -0.06 \\
\hline Dist to Water & 0.07 & -0.26 & -0.01 & 0.02 \\
\hline Rhododendron & -0.05 & -0.19 & 0.29 & -0.35 \\
\hline SDIALL & -0.33 & 0.34 & 0.25 & -0.001 \\
\hline CAN1 & -0.28 & -0.07 & 0.42 & -0.12 \\
\hline CAN2 & -0.25 & -0.08 & 0.51 & 0.08 \\
\hline CAN3 & -0.35 & -0.14 & 0.14 & 0.23 \\
\hline CAN4 & -0.18 & 0.18 & -0.34 & 0.14 \\
\hline CAN5 & -0.08 & 0.47 & -0.10 & -0.15 \\
\hline CAN6 & 0.11 & 0.42 & 0.21 & -0.13 \\
\hline \multicolumn{5}{|l|}{ Dry Oak Points } \\
\hline Eigenvalue & 3.16 & 2.34 & 2.13 & 1.51 \\
\hline Percent & 18.6 & 13.8 & 12.5 & 8.88 \\
\hline Cum Percent & 18.6 & 32.4 & 44.9 & 53.8 \\
\hline Slope & $\begin{array}{l}-0.02 \\
\end{array}$ & 0.26 & $\begin{array}{c}-0.13 \\
\end{array}$ & 0.35 \\
\hline Aspect & 0.01 & -0.10 & 0.004 & 0.30 \\
\hline Elevation & 0.05 & -0.01 & -0.03 & 0.69 \\
\hline US Conifer & 0.22 & -0.30 & 0.27 & 0.21 \\
\hline OS Conifer & 0.24 & -0.28 & 0.34 & -0.19 \\
\hline Sum Conifer & 0.30 & -0.37 & 0.40 & -0.03 \\
\hline Dist to Water & -0.02 & -0.03 & 0.08 & 0.38 \\
\hline Height & 0.39 & 0.23 & -0.09 & -0.06 \\
\hline Rhododendron & 0.06 & 0.09 & 0.12 & -0.06 \\
\hline SDIALL & 0.20 & 0.51 & 0.31 & -0.01 \\
\hline CAN1 & -0.24 & 0.20 & 0.25 & -0.14 \\
\hline CAN2 & -0.37 & 0.19 & 0.31 & 0.003 \\
\hline CAN3 & -0.24 & 0.23 & 0.43 & 0.08 \\
\hline CAN4 & 0.22 & 0.19 & 0.34 & 0.15 \\
\hline CAN5 & 0.42 & 0.24 & -0.03 & -0.04 \\
\hline CAN6 & 0.34 & 0.26 & -0.22 & -0.07 \\
\hline
\end{tabular}


Table A-10. Significance of site variable effect on bird abundance for selected uncommon species. $p$ values shown are the probability that the parameter tested is greater than Wald's chi-square., and are included for all $p<0.15$. Plus/minus signs indicate whether the association of the variable is positive or negative, e.g., "-Elev" neans the species is associated with lower elevations.

\begin{tabular}{|c|c|c|c|c|}
\hline Species & $\begin{array}{l}\text { PC } \\
\text { Axis }\end{array}$ & Variable(s) & $p$ & $\mathbf{n}$ \\
\hline \multicolumn{5}{|l|}{ Mixed Mesophytic } \\
\hline \multirow[t]{2}{*}{ Brown-headed cowbird } & II & + SUMCON & 0.02 & 19 \\
\hline & III & + SUMCON & 0.02 & 19 \\
\hline \multirow{11}{*}{ Cerulean warbler } & III & +STANDHT & 0.09 & 24 \\
\hline & & -CAN6 & 0.02 & 24 \\
\hline & III & $\begin{array}{l}\text { +DTW } \\
\text { +CAN1 }\end{array}$ & $\begin{array}{l}\mathbf{0 . 0 2} \\
0.11\end{array}$ & $\begin{array}{l}24 \\
24\end{array}$ \\
\hline & $\begin{array}{l}\text { IV } \\
\text { V }\end{array}$ & $\begin{array}{l}\text { +DTW } \\
\text { +DTW }\end{array}$ & $\begin{array}{l}0.01 \\
0.01\end{array}$ & $\begin{array}{l}24 \\
24\end{array}$ \\
\hline & & -CAN6 & 0.11 & 24 \\
\hline & VI & $+\mathrm{PA}$ & 0.10 & 16 \\
\hline & & -ASPECTT & 0.10 & 16 \\
\hline & & +CAN4 & 0.04 & 16 \\
\hline & VII & $+\mathbf{P A}$ & $\mathbf{0 . 0 3}$ & 14 \\
\hline & & -ASPECTT & 0.045 & 14 \\
\hline & & +CAN4 & 0.01 & 14 \\
\hline \multirow[t]{7}{*}{ Louisiana waterthrush } & I & +SDIALL & 0.046 & 16 \\
\hline & & -CAN4 & 0.10 & 16 \\
\hline & II & $\begin{array}{l}\text { +CAN2 } \\
+ \text { CAN5 } \\
\end{array}$ & $\begin{array}{l}0.05 \\
0.03 \\
\end{array}$ & $\begin{array}{l}16 \\
16 \\
\end{array}$ \\
\hline & III & $\begin{array}{l}\text {-DTW } \\
\text {-SDIALL } \\
\text {-CAN4 }\end{array}$ & $\begin{array}{l}0.07 \\
0.07 \\
0.12\end{array}$ & $\begin{array}{l}16 \\
16 \\
16\end{array}$ \\
\hline & IV & $\begin{array}{l}\text { +STANDHT } \\
\text {-DTW }\end{array}$ & $\begin{array}{c}0.08 \\
\mathbf{0 . 0 4 6}\end{array}$ & $\begin{array}{l}16 \\
16\end{array}$ \\
\hline & $\mathrm{V}$ & $\begin{array}{l}\text {-DTW } \\
+ \text { +CAN6 }\end{array}$ & $\begin{array}{l}\mathbf{0 . 0 3} \\
0.11\end{array}$ & $\begin{array}{l}16 \\
16\end{array}$ \\
\hline & $\begin{array}{l}\text { VI } \\
\text { VII }\end{array}$ & $\begin{array}{l}- \text {-DTW } \\
+ \text { CAN2 }\end{array}$ & $\begin{array}{l}0.06 \\
0.09\end{array}$ & $\begin{array}{l}14 \\
14\end{array}$ \\
\hline
\end{tabular}


Table A-10 (Continued) Significance of site variable effect on bird abundance for selected uncommon species. $p$ values shown are the probability that the parameter tested is greater than Wald's chi-square., and are included for all $p<0.15$. Plus/minus signs indicate whether the nature of the association; e.g., "-Elev" indicates the species is more common at lower elevations.

\begin{tabular}{|c|c|c|c|c|}
\hline Species & $\begin{array}{l}\text { PC } \\
\text { Axis } \\
\end{array}$ & Variable(s) & $\mathbf{p}$ & $\mathbf{n}$ \\
\hline \multicolumn{5}{|l|}{ Northern Hardwoods } \\
\hline \multirow[t]{11}{*}{ Hooded warbler } & I & +STANDHT & 0.10 & 12 \\
\hline & & -CAN6 & 0.03 & 12 \\
\hline & II & -WDTE & 0.08 & 12 \\
\hline & & +CAN4 & 0.13 & 12 \\
\hline & III & -OSCON & 0.13 & 9 \\
\hline & & +SUMCON & 0.11 & 9 \\
\hline & & -WDTE & 0.08 & 9 \\
\hline & IV & + CAN4 & 0.04 & 12 \\
\hline & $\mathrm{V}$ & -WDTE & 0.146 & 12 \\
\hline & & +RHMA & 0.03 & 12 \\
\hline & VI & -CAN6 & 0.06 & 9 \\
\hline \multirow[t]{10}{*}{ Brown-headed cowbird } & I & +STANDHT & 0.14 & 6 \\
\hline & & -CAN6 & 0.07 & 6 \\
\hline & II & +STANDHT & 0.13 & 6 \\
\hline & III & -CAN6 & 0.14 & 6 \\
\hline & IV & +SLOPE & 0.04 & 6 \\
\hline & $\mathrm{V}$ & -SDIALL & 0.10 & 6 \\
\hline & VI & +SLOPE & 0.05 & 6 \\
\hline & & +STANDHT & 0.03 & 6 \\
\hline & & -CAN1 & 0.12 & 6 \\
\hline & & -CAN6 & 0.04 & 6 \\
\hline \multirow{5}{*}{ Louisiana waterthrush } & I & -ELEV & 0.06 & 5 \\
\hline & III & $+\mathrm{OSCON}$ & 0.09 & 5 \\
\hline & IV & -SUMCON & 0.13 & 5 \\
\hline & V & -CAN1 & 0.05 & 5 \\
\hline & VI & -ELEV & 0.07 & 5 \\
\hline \multicolumn{5}{|l|}{ Red Spruce } \\
\hline \multirow[t]{9}{*}{ Hooded warbler } & I & + ELEV & 0.13 & \\
\hline & & -SDIALL & 0.09 & \\
\hline & & + CAN & 0.14 & \\
\hline & II & +ELEV & 0.05 & \\
\hline & & -STANDHT & 0.45 & \\
\hline & & +DTW & 0.01 & \\
\hline & VI & -SLOPE & 0.14 & \\
\hline & & + +ELEV & 0.03 & \\
\hline & & +DTW & 0.004 & \\
\hline
\end{tabular}


Table A-10 (Continued) Significance of site variable effect on bird abundance for selected uncommon species. $p$ values shown are the probability that the parameter tested is greater than Wald's chi-square., and are included for all $\mathbf{p}<\mathbf{0 . 1 5}$. Plus/minus signs indicate whether the nature of the association; e.g., "-Elev" indicates the species is more common at lower elevations.

\begin{tabular}{|c|c|c|c|c|}
\hline Species & $\begin{array}{l}\text { PC } \\
\text { Axis }\end{array}$ & Variable(s) & $\mathbf{p}$ & $\mathbf{n}$ \\
\hline \multicolumn{5}{|l|}{ Dry Oaks } \\
\hline \multirow[t]{5}{*}{ Brown-headed cowbird } & I & -CAN2 & 0.09 & 22 \\
\hline & II & -SLOPE & 0.02 & 22 \\
\hline & III & $\begin{array}{l}\text { +STANDHT } \\
\text {-SDIALL }\end{array}$ & $\begin{array}{l}0.06 \\
0.09\end{array}$ & $\begin{array}{l}22 \\
22\end{array}$ \\
\hline & IV & $\begin{array}{l}\text {-CAN2 } \\
\text {-SLOPE }\end{array}$ & $\begin{array}{l}\mathbf{0 . 0 2} \\
0.10\end{array}$ & $\begin{array}{l}22 \\
22 \\
\end{array}$ \\
\hline & $\mathrm{V}$ & $\begin{array}{l}\text { +WDTE } \\
\text {-SLOPE }\end{array}$ & $\begin{array}{l}0.11 \\
\mathbf{0 . 0 2}\end{array}$ & $\begin{array}{l}22 \\
20 \\
\end{array}$ \\
\hline \multirow[t]{5}{*}{ Hooded warbler } & III & +CAN1 & 0.14 & 11 \\
\hline & IV & + ELEV & 0.05 & 11 \\
\hline & & + USCON & 0.11 & 11 \\
\hline & $\mathrm{V}$ & +CAN3 & $\mathbf{0 . 0 3}$ & 11 \\
\hline & VI & +CAN1 & 0.07 & 11 \\
\hline \multirow[t]{3}{*}{ Cerulean warbler } & I & +CAN5 & 0.11 & 10 \\
\hline & II & + SLOPE & 0.056 & 10 \\
\hline & $\begin{array}{l}\text { V } \\
\text { VI }\end{array}$ & $\begin{array}{l}\text { +SLOPE } \\
\text {-ASPECTT } \\
\text {-ELEV } \\
\text {-ASPECTT } \\
\text { +SLOPE }\end{array}$ & $\begin{array}{l}\mathbf{0 . 0 0 7} \\
0.13 \\
0.10 \\
0.09 \\
\mathbf{0 . 0 5}\end{array}$ & $\begin{array}{l}10 \\
10 \\
10 \\
10 \\
10\end{array}$ \\
\hline Louisiana waterthrush & IV & $\begin{array}{l}\text { +WDTE } \\
\text { +SLOPE } \\
\text {-ELEV } \\
\text {-ASPECTT } \\
\text { +USCON } \\
\text {-ASPECTT }\end{array}$ & $\begin{array}{l}0.11 \\
\mathbf{0 . 0 4} \\
\mathbf{0 . 0 4} \\
\mathbf{0 . 0 4} \\
0.07 \\
0.08 \\
\end{array}$ & $\begin{array}{l}8 \\
8 \\
8 \\
8 \\
8 \\
8 \\
\end{array}$ \\
\hline \multirow[t]{4}{*}{ Yellow-billed cuckoo } & II & +SDIALL & 0.10 & 5 \\
\hline & & + CAN3 & 0.12 & 5 \\
\hline & III & $+\mathrm{CAN} 2$ & 0.12 & 5 \\
\hline & & + CAN4 & 0.13 & 5 \\
\hline
\end{tabular}


Table A-11. Comparison of mean abundance per sample point by bird group for each of the six mixed mesophytic study areas (landscapes), Monongahela National Forest, 1996-1997. Study areas are listed in order of increasing forest intactness (decreasing fragmentation). Means followed by the same letter are not significantly different at $\mathbf{p}=\mathbf{0 . 0 5}$. PIF species are those of special concern, designated by West Virginia Partners in Flight.

\begin{tabular}{|c|c|c|c|c|c|c|}
\hline & Clover Run & Parsons & Valley Head & Location & $\begin{array}{l}\text { Chestnut } \\
\text { Ridge }\end{array}$ & Otter Creek \\
\hline Forested Core Area & $42 \%$ & $54 \%$ & $58 \%$ & $61 \%$ & $73 \%$ & $85 \%$ \\
\hline $\begin{array}{l}\text { Edge Density } \\
(\mathrm{m} / 100 \mathrm{ha})\end{array}$ & 58 & 42 & 39 & 34 & 21 & 8 \\
\hline Bird Abundance & Mean/MSE/n & Mean/MSE/n & Mean/MSE/n & Mean/MSE/n & Mean/MSE/n & Mean/MSE/n \\
\hline All birds & 9.5A/38.3/94 & 9.2A/38.3/88 & 7.9A/38.3/94 & 9.4A/38.3/90 & 7.7A/38.3/88 & 9.1A/38.3/94 \\
\hline \multicolumn{7}{|l|}{ Nesting guilds } \\
\hline Ground nesters & 2.7A/1.7/69 & 2.2AB/1.7/63 & $\mathbf{2 . 0 B} / 1.7 / 57$ & $\mathbf{2 . 0 B} / 1.7 / 57$ & $\mathbf{1 . 8 B} / 1.7 / 57$ & 2.4AB/1.7/63 \\
\hline High canopy & 2.2AB/1.2/68 & 1.7B/1.2/71 & 2.1AB/1.2/76 & 2.0AB/1.2/72 & $\mathbf{1 . 7 B} / 1.2 / 73$ & 2.3A/1.2/84 \\
\hline Cavity nesters & 2.5AB/1.3/88 & $\mathbf{2 . 4 B} / 1.3 / 81$ & 2.2AB/1.3/78 & 2.5AB/1.3/82 & 2.1B/1.3/76 & 3.0A/1.3/92 \\
\hline Low canopy & 4.5A/11.2/94 & 3.9A/11.2/87 & 3.5A/11.2/85 & 3.9A/11.2/90 & 3.6A/11.2/85 & 3.6A/11.2/90 \\
\hline Shrub layer & 2.6A/1.4/45 & 2.2AB/1.4/62 & 1.8B/1.4/41 & 2.5A/1.4/45 & 1.9B/1.4/44 & 2.4AB/1.4/74 \\
\hline \multicolumn{7}{|l|}{ Migratory guilds } \\
\hline Neotropical & 7.8A/26.4/94 & 7.6A/26.4/88 & 6.2A/26.4/93 & 7.9A/26.4/90 & 6.5A/26.4/88 & 7.9A/26.4/94 \\
\hline Residents & 1.7A/1.1/46 & 1.6A/1.1/42 & 1.8A/1.1/39 & 1.6A/1.1/42 & $\mathbf{1 . 4 A} / 1.1 / 40$ & $1.7 \mathrm{~A} / 1.1 / 32$ \\
\hline Short-Distance & $1.7 \mathrm{~A} / 0.4 / 43$ & $1.4 \mathrm{AB} / 0.4 / 32$ & 1.3AB/0.4/25 & $1.7 \mathrm{~A} / 0.4 / 27$ & $1.2 \mathrm{~B} / 0.4 / 29$ & 1.4AB/0.4/31 \\
\hline \multicolumn{7}{|l|}{ Foraging Guilds } \\
\hline Ground gleaners & 2.7A/1.7/69 & $2.2 \mathrm{AB} / 1.7 / 62$ & $2.0 \mathrm{~B} / 1.7 / 57$ & 2.0B/1.7/57 & $\mathbf{1 . 8 B} / 1.7 / 57$ & 2.4AB/1.7/63 \\
\hline Foliage gleaners & 1.1CD/0.04/21 & 1.4AB/0.04/33 & $1.0 \mathrm{D} / 0.04 / 12$ & 1.2BCD $/ 0.04 / 2$ & $1.4 \mathrm{~A} / 0.04 / 23$ & 1.3ABC/0.04/ \\
\hline High canopy & 2.5B/1.2/88 & 2.4B/1.2/81 & 2.2B/1.2/78 & 2.5B/1.2/82 & 2.1B/1.2/76 & 3.0A/1.2/92 \\
\hline Bark & $1.4 \mathrm{AB} / 0.06 / 26$ & 1.3BC $/ 0.06 / 35$ & $\mathbf{1 . 5 A} / 0.06 / 32$ & 1.4B/0.06/31 & $1.2 \mathrm{C} / 0.06 / 33$ & 1.3BC/0.06/27 \\
\hline Mixed & 4.4A/12.9/88 & 4.2A/12.9/86 & 3.8A/12.9/90 & 5.0A/12.9/88 & 3.9A/12.9/84 & 3.9A/12.9/92 \\
\hline \multicolumn{7}{|l|}{ Habitat Guilds } \\
\hline Edge & $2.2 \mathrm{~A} / 2.0 / 50$ & $1.7 \mathrm{~A} / 2.0 / 33$ & $1.7 \mathrm{~A} / 2.0 / 30$ & $2.1 \mathrm{~A} / 2.0 / 35$ & 1.8A/2.0/35 & $2.2 \mathrm{~A} / 2.0 / 22$ \\
\hline Interior-Edge & $\mathbf{3 . 8 A} / 5.1 / 89$ & 3.2AB/5.1/89 & 2.9AB/5.1/91 & 3.4AB/5.1/85 & $\mathbf{2 . 8 B} / 5.1 / 84$ & 3.2AB/5.1/90 \\
\hline Forest Interior & 4.6A/8.9/94 & 5.2A/8.9/87 & 4.3A/8.9/86 & 5.1A/8.9/89 & 4.2A/8.9/87 & 5.4A/8.9/93 \\
\hline \multicolumn{7}{|l|}{ PIF Species } \\
\hline Acadian flycatcher & 0.7A $/ 0.9 / 94$ & $\mathbf{0 . 6 A} / 0.9 / 88$ & 0.7A $/ 0.9 / 94$ & 0.6A/0.9/90 & $\mathbf{0 . 5 A} / 0.9 / 88$ & 0.4A/0.9/94 \\
\hline Cerulean warbler & 0.2A/0.1/94 & 0.1A $/ 0.1 / 88$ & 0.2A $/ 0.1 / 94$ & 0.1A $/ 0.1 / 90$ & 0.2A $/ 0.1 / 88$ & 0.1A/0.2/94 \\
\hline E. wood peewee & 0.3A/0.4/94 & 0.1A/0.4/94 & 0.2A/0.4/94 & $\mathbf{0 . 2 A} / 0.4 / 90$ & 0.2A $/ 0.4 / 88$ & $\mathbf{0 . 1 A} / 0.4 / 94$ \\
\hline Hooded warbler & 0.3BC/0.5/94 & 0.5AB/ $/ 0.5 / 88$ & $\mathbf{0 . 1 C} / 0.5 / 94$ & $\mathbf{0 . 6 A} / 0.5 / 90$ & $\mathbf{0 . 2 C} / 0.5 / 94$ & $\mathbf{0 . 1 C} / 0.5 / 94$ \\
\hline Louisiana waterthrush & 0.06A/0.4/94 & 0.11A/ $/ 0.4 / 88$ & 0.08A/0.4/94 & 0.08A $/ 0.4 / 90$ & $\mathbf{0 . 0 5} \mathbf{A} / 0.4 / 88$ & 0.07A/0.4/94 \\
\hline Red-eyed vireo & $\mathbf{1 . 5 \mathrm { A }} / 2.3 / 94$ & $\mathbf{1 . 3 A} / 2.3 / 88$ & 1.4A/2.3/94 & $\mathbf{1 . 7 A} / 2.3 / 90$ & $1.2 \mathrm{~A} / 2.3 / 88$ & $\mathbf{1 . 4 A} / 2.3 / 94$ \\
\hline Scarlet tanager & $\mathbf{0 . 5 A} / 0.8 / 94$ & $\mathbf{0 . 5 A} / 0.8 / 88$ & 0.6A/0.8/94 & 0.6A $/ 0.8 / 90$ & $\mathbf{0 . 5 A} / 0.8 / 88$ & $\mathbf{0 . 4 A} / 0.8 / 94$ \\
\hline Wood thrush & 0.5A/2.6/94 & 0.5A/2.6/88 & 0.4A/2.6/94 & $\mathbf{0 . 3 A} / 2.6 / 90$ & 0.4A/2.6/94 & 0.4A/2.6/94 \\
\hline Worm-eating warbler & 0.13A/0.3/94 & 0.07A/0.3/88 & 0.02A/0.3/94 & 0.09A/0.3/90 & $\mathbf{0 . 1 3 A} / 0.3 / 88$ & 0.01A/0.3/94 \\
\hline
\end{tabular}


Table A-12. Comparison of mean species richness per sample point by bird group for each of the six mixed mesophytic study areas (landscapes), Monongahela National Forest, West Virginia, 1996-1997. Study areas are listed in order of increasing forest intactness (decreasing fragmentation). Means followed by the same letter are not significantly different at $\mathrm{p}=0.05$.

\begin{tabular}{|c|c|c|c|c|c|c|}
\hline & Clover Run & Parsons & Valley Head & Location & $\begin{array}{l}\text { Chestnut } \\
\text { Ridge }\end{array}$ & Otter Creek \\
\hline Forested Core Area & $42 \%$ & $54 \%$ & $58 \%$ & $61 \%$ & $73 \%$ & $85 \%$ \\
\hline $\begin{array}{l}\text { Edge Density } \\
(\mathrm{m} / 100 \mathrm{ha})\end{array}$ & 58 & 42 & 39 & 34 & 21 & 8 \\
\hline Bird Species Richness & Mean/MSE/n & Mean/MSE/n & Mean/MSE/n & Mean/MSE/n & Mean/MSE/n & Mean/MSE/n \\
\hline All birds & 7.4A/23.0/94 & 7.7A/23.0/88 & 6.2A $/ 23.0 / 88$ & $7.2 \mathrm{~A} / 23.0 / 90$ & 6.5A/23.0/88 & 7.0A/23.0/94 \\
\hline \multicolumn{7}{|l|}{ Nesting guilds } \\
\hline Ground nesters & 1.3AB $/ 0.2 / 70$ & 1.5A/0.2/69 & 1.2B/0.2/47 & 1.4AB/0.2/71 & $1.4 \mathrm{AB} / 0.2 / 50$ & 1.3B/0.2/48 \\
\hline High canopy & 1.8AB/0.6/68 & 1.6AB/0.6/71 & 1.7AB $/ 0.6 / 76$ & 1.7AB/0.6/72 & 1.5B/0.6/73 & 1.9A/0.6/84 \\
\hline Cavity nesters & 1.5AB/0.2/43 & 1.4AB $/ 0.2 / 38$ & 1.6AB/0.2/39 & 1.5A/0.2/36 & 1.2B/0.2/43 & 1.3AB $/ 0.2 / 48$ \\
\hline Low canopy & 3.2A/5.5/94 & 3.0A/5.5/87 & 2.5A/5.5/92 & $2.6 \mathrm{~A} / 5.5 / 90$ & 2.8A/5.5/85 & $2.5 \mathrm{~A} / 5.5 / 90$ \\
\hline Shrub layer & 2.0A/0.5/45 & 1.9AB $/ 0.5 / 62$ & $1.6 B / 0.5 / 41$ & 2.0A/0.5/56 & 1.7AB/0.5/44 & 1.8AB $/ 0.5 / 74$ \\
\hline \multicolumn{7}{|l|}{ Migratory guilds } \\
\hline Neotropical & 5.9A/14.9/94 & 6.2A/14.9/88 & 4.8A/14.9/93 & 5.8A/14.9/90 & $\mathbf{5 . 3 A} / 14.9 / 88$ & 5.9A/14.9/94 \\
\hline Residents & 1.5A/1.0/46 & 1.5A/1.0/42 & 1.5A/1.0/39 & 1.5A/1.0/42 & 1.3A/1.0/40 & 1.4A/1.0/32 \\
\hline Short-Distance & $\mathbf{1 . 2 A} / 0.2 / 43$ & $\mathbf{1 . 3 A} / 0.2 / 32$ & $1.2 \mathrm{~A} / 0.2 / 25$ & $\mathbf{1 . 4 A} / 0.2 / 27$ & 1.1A/0.2/29 & 1.2A/0.2/31 \\
\hline \multicolumn{7}{|l|}{ Foraging Guilds } \\
\hline Ground gleaners & 2.2A/1.2/69 & 1.9AB/1.2/62 & 1.6B/1.2/57 & 1.7AB/1.2/57 & 1.6B/1.2/57 & 1.9AB/1.2/63 \\
\hline Foliage gleaners & 1.0B/0.01/21 & 1.0AB/0.0/33 & 1.0B/0.01/12 & 1.0AB $/ 0.01 / 23$ & 1.1A/0.01/23 & 1.0B/0.01/13 \\
\hline High canopy & 2.0AB/1.4/88 & 2.0AB/1.4/81 & 1.8B/1.4/78 & 2.0AB/1.4/82 & $\mathbf{1 . 8 B} / 1.4 / 76$ & 2.3A/1.4/92 \\
\hline Bark & $\mathbf{1 . 3 A} / 0.03 / 26$ & $1.2 B C / 0.0 / 35$ & 1.3AB/0.03/32 & $1.3 \mathrm{AB} / 0.03 / 32$ & $1.1 \mathrm{D} / 0.03 / 33$ & $1.2 \mathrm{CD} / 0.0 / 27$ \\
\hline Mixed & 3.2A/4.5/93 & 3.4A/4.5/86 & 2.8A/4.5/90 & 3.5A/4.5/88 & 3.1A/4.5/84 & 2.9A/4.5/92 \\
\hline \multicolumn{7}{|l|}{ Habitat Guilds } \\
\hline Edge & 1.7A/0.5/50 & $\mathbf{1 . 5 A} / 0.5 / 33$ & $1.4 \mathrm{~A} / 0.5 / 30$ & 1.6A/0.5/35 & $\mathbf{1 . 5 A} / 0.5 / 35$ & 1.6A/0.5/22 \\
\hline Interior-Edge & 2.8A/2.4/89 & 2.5AB/2.4/85 & 2.1B/2.4/91 & 2.4AB/2.4/85 & 2.1B/2.4/84 & 2.2AB/2.4/90 \\
\hline Forest Interior & 3.7A/7.0/94 & 4.5A/7.0/87 & 3.6A/7.0/86 & $4.1 \mathrm{~A} / 7.0 / 89$ & 3.7A/7.0/87 & 4.3A/7.0/93 \\
\hline
\end{tabular}


Table A-13. Comparison of least-squares mean abundance and species richness per transect by selected bird groups, Monongahela National Forest., West Virginia, 1996-1997. n=number of sample points in the transect.

\begin{tabular}{|c|c|c|c|c|c|c|}
\hline \multirow{3}{*}{ Transect } & \multicolumn{3}{|c|}{ Bird Abundance } & \multicolumn{3}{|c|}{ Bird Species Richness } \\
\hline & All Birds & $\begin{array}{l}\text { Neotropical } \\
\text { Migrants } \\
\end{array}$ & $\begin{array}{l}\text { Low Canopy } \\
\text { Nesters }\end{array}$ & All Birds & $\begin{array}{l}\text { Neotropical } \\
\text { Migrants } \\
\end{array}$ & $\begin{array}{l}\text { Low Canopy } \\
\text { Nesters }\end{array}$ \\
\hline & "LSMean/MSE/n & "LSMean/MSE/n & "LSMean/MSE/n & "LSMean/MSE/n & "LSMean/MSE/n & LSMean/MSE/n \\
\hline Clover Run 13 & $9.2 / 13.4 / 11$ & $7.3 / 8.6 / 11$ & $4.1 / 3.3 / 11$ & $6.9 / 8.0 / 11$ & $5.3 / 4.7 / 11$ & $2.8 / 1.6 / 11$ \\
\hline Clover Run 14 & $8.4 / 13.4 / 11$ & $6.8 / 8.6 / 11$ & $4.0 / 3.3 / 11$ & $6.8 / 8.0 / 11$ & $5.7 / 4.7 / 11$ & $2.9 / 1.6 / 11$ \\
\hline Clover Run 15 & $12.6 / 13.4 / 12$ & $10.5 / 8.6 / 12$ & $6.0 / 3.3 / 12$ & $9.7 / 8.0 / 12$ & $7.7 / 4.7 / 12$ & $4.2 / 1.6 / 12$ \\
\hline Clover Run 16 & $7.2 / 13.4 / 12$ & $6.2 / 8.6 / 12$ & $3.8 / 3.3 / 12$ & $5.9 / 8.0 / 12$ & $4.9 / 4.7 / 12$ & $2.8 / 1.6 / 12$ \\
\hline Parsons 9 & $11.6 / 13.4 / 11$ & $9.1 / 8.6 / 11$ & $4.6 / 3.3 / 11$ & $10.1 / 8.0 / 11$ & $7.8 / 4.7 / 11$ & $3.7 / 1.6 / 11$ \\
\hline Parsons 10 & $7.3 / 13.4 / 11$ & $6.2 / 8.6 / 11$ & $3.1 / 3.3 / 11$ & $6.2 / 8.0 / 11$ & $5.2 / 4.7 / 11$ & $2.5 / 1.6 / 11$ \\
\hline Parsons 11 & $9.4 / 13.4 / 11$ & $8.1 / 8.6 / 11$ & $3.9 / 3.3 / 11$ & $8.1 / 8.0 / 11$ & $6.8 / 4.7 / 11$ & $3.3 / 1.6 / 11$ \\
\hline Parsons 12 & $8.3 / 13.4 / 11$ & $7.0 / 8.6 / 11$ & $4.0 / 3.3 / 11$ & $6.4 / 8.0 / 11$ & $5.1 / 4.7 / 11$ & $2.6 / 1.6 / 11$ \\
\hline Valley Head 25 & $8.7 / 13.4 / 11$ & $6.4 / 8.6 / 11$ & $3.1 / 3.3 / 11$ & $7.0 / 8.0 / 11$ & $5.1 / 4.7 / 11$ & $2.5 / 1.6 / 11$ \\
\hline Valley Head 26 & $8.9 / 13.4 / 14$ & $6.8 / 8.6 / 14$ & $4.3 / 3.3 / 14$ & $6.5 / 8.0 / 14$ & $4.8 / 4.7 / 14$ & $2.6 / 1.6 / 14$ \\
\hline Valley Head 27 & $6.3 / 13.4 / 11$ & $5.5 / 8.6 / 11$ & $3.0 / 3.3 / 11$ & $5.2 / 8.0 / 11$ & $4.5 / 4.7 / 11$ & $2.3 / 1.6 / 11$ \\
\hline Valley Head 28 & $7.3 / 13.4 / 11$ & $6.0 / 8.6 / 11$ & $3.1 / 3.3 / 11$ & $6.0 / 8.0 / 11$ & $4.8 / 4.7 / 11$ & $2.3 / 1.6 / 11$ \\
\hline Location 1 & $210.9 / 13.4 / 10$ & 9.0/8.6/10 & 4.4/3.3/10 & $8.6 / 8.0 / 10$ & $6.8 / 4.7 / 10$ & $3.1 / 1.6 / 10$ \\
\hline Location 2 & $8.5 / 13.4 / 18$ & $7.2 / 8.6 / 18$ & $3.6 / 3.3 / 18$ & $6.3 / 8.0 / 18$ & $5.3 / 4.7 / 18$ & $2.3 / 1.6 / 18$ \\
\hline Location 3 & $6.9 / 13.4 / 9$ & $5.9 / 8.6 / 9$ & $3.5 / 3.3 / 9$ & $9.2 / 8.0 / 9$ & $4.6 / 4.7 / 9$ & $2.5 / 1.6 / 9$ \\
\hline Location 4 & $12.6 / 13.4 / 8$ & $10.3 / 8.6 / 8$ & $4.6 / 3.3 / 8$ & $5.6 / 8.0 / 8$ & $7.4 / 4.7 / 8$ & $2.8 / 1.6 / 8$ \\
\hline Chestnut Ridge 41 & $8.7 / 13.4 / 11$ & $6.8 / 8.6 / 11$ & $3.6 / 3.3 / 11$ & $7.5 / 8.0 / 11$ & 5.5/4.7/11 & $2.9 / 1.6 / 11$ \\
\hline Chestnut Ridge 42 & 7.2/13.4/11 & $6.1 / 8.6 / 11$ & $3.3 / 3.3 / 11$ & $5.9 / 8.0 / 11$ & $4.9 / 4.7 / 11$ & $2.4 / 1.6 / 11$ \\
\hline Chestnut Ridge 43 & $7.8 / 13.4 / 11$ & $6.6 / 8.6 / 11$ & $3.3 / 3.3 / 11$ & $6.4 / 8.0 / 11$ & $5.4 / 4.7 / 11$ & $2.6 / 1.6 / 11$ \\
\hline Chestnut Ridge 44 & $6.9 / 13.4 / 11$ & $6.0 / 8.6 / 11$ & $4.1 / 3.3 / 11$ & $6.0 / 8.0 / 11$ & $5.1 / 4.7 / 11$ & $3.2 / 1.6 / 11$ \\
\hline Otter Creek 5 & $7.2 / 13.4 / 14$ & $5.8 / 8.6 / 14$ & $3.1 / 3.3 / 14$ & $5.4 / 8.0 / 14$ & $4.5 / 4.7 / 14$ & $1.9 / 1.6 / 11$ \\
\hline Otter Creek 6 & $10.5 / 13.4 / 11$ & $9.1 / 8.6 / 11$ & $3.9 / 3.3 / 11$ & $8.1 / 8.0 / 11$ & $6.8 / 4.7 / 11$ & $2.8 / 1.6 / 11$ \\
\hline Otter Creek 7 & $9.6 / 13.4 / 10$ & $8.4 / 8.6 / 10$ & $4.4 / 3.3 / 10$ & $7.6 / 8.0 / 10$ & $6.5 / 4.7 / 10$ & $3.1 / 1.6 / 11$ \\
\hline Otter Creek 8 & $9.6 / 13.4 / 11$ & $8.6 / 8.6 / 11$ & $3.3 / 3.3 / 11$ & $7.2 / 8.0 / 11$ & $6.2 / 4.7 / 11$ & $2.3 / 1.6 / 11$ \\
\hline
\end{tabular}


Table A-14. Results of significance tests for differences in clutch size, Monongahela National Forest nest search study areas (landscapes)/plots, 1996-1997. Asterisks indicate sample size too small for comparison.

\begin{tabular}{|c|c|c|}
\hline \multirow{3}{*}{ Bird Group } & \multicolumn{2}{|c|}{ Test for Significant Differences in Clutch Size } \\
\hline & Landscape Effect & Plot Effect \\
\hline & F value/df/p value & F value/df/p value \\
\hline All Birds & $2.87 / 4 / \mathbf{0 . 0 2}$ & $1.23 / 5 / 0.29$ \\
\hline \multicolumn{3}{|l|}{ Nesting Guilds } \\
\hline Ground nesters & $1.79 / 2 / 0.28$ & $4.14 / 3 / 0.14$ \\
\hline High Canopy & $1.61 / 4 / 0.25$ & $1.37 / 7 / 0.34$ \\
\hline Cavity Nesters & $0.18 / 2 / 0.84$ & $*(\mathrm{n}=9)$ \\
\hline Low Canopy & $1.41 / 4 / 0.23$ & $1.27 / 9 / 0.26$ \\
\hline Shrub Layer & $0.44 / 4 / 0.78$ & $1.19 / 8 / 0.32$ \\
\hline \multicolumn{3}{|c|}{ "Migratory Guilds } \\
\hline Neotropical & $1.89 / 4 / 0.11$ & $1.23 / 9 / 0.28$ \\
\hline Residents & $2.92 / 4 / 0.14$ & $*(\mathrm{n}=10)$ \\
\hline Short-Distance & $0.57 / 3 / 0.65$ & $0.93 / 4 / 0.49$ \\
\hline \multicolumn{3}{|c|}{ Foraging Guilds } \\
\hline Ground gleaners & $2.84 / 4 / \mathbf{0 . 0 3}$ & $1.64 / 5 / 0.16$ \\
\hline Foliage gleaners & $*(\mathrm{n}=3)$ & $*(\mathrm{n}=3)$ \\
\hline High canopy & $0.78 / 4 / 0.54$ & $2.72 / 5 / \mathbf{0 . 0 3}$ \\
\hline Bark & $*(\mathrm{n}=4)$ & $*(n=4)$ \\
\hline Mixed & $1.11 / 4 / 0.36$ & $0.62 / 5 / 0.68$ \\
\hline \multicolumn{3}{|l|}{ Habitat Guilds } \\
\hline Edge & $1.28 / 4 / 0.30$ & $1.33 / 4 / 0.28$ \\
\hline Interior-Edge & $1.62 / 4 / 0.17$ & $1.03 / 5 / 0.40$ \\
\hline Forest Interior & $1.54 / 4 / 0.20$ & $0.98 / 5 / 0.43$ \\
\hline \multicolumn{3}{|l|}{ PIF Species } \\
\hline Red-eyed vireo & $0.58 / 4 / 0.68$ & $0.85 / 7 / 0.56$ \\
\hline Wood thrush & $3.87 / 4 / \mathbf{0 . 0 0 7}$ & $1.80 / 5 / 0.13$ \\
\hline
\end{tabular}


Table A-15. Results of significance tests for nest survival related to distance from edge, Monongahela National Forest, West Virginia, 1996-1997 . Asterisks indicate sample size too small for comparison.

\begin{tabular}{|c|c|}
\hline \multirow{2}{*}{ Bird Group } & $\begin{array}{l}\text { Test for Significant Effect of } \\
\text { Distance to Edge on Nest Survival }\end{array}$ \\
\hline & Wald's chi-square/p/no. of nests \\
\hline All Birds & $6.38 / \mathbf{0 . 0 1} / 379$ \\
\hline \multicolumn{2}{|l|}{ Nesting Guilds } \\
\hline Ground nesters & $2.59 / 0.11 / 17$ \\
\hline High Canopy & $0.48 / 0.49 / 35$ \\
\hline Cavity Nesters & $*(\mathrm{n}=3)$ \\
\hline Low Canopy & $1.52 / 0.22 / 221$ \\
\hline Shrub Layer & $2.32 / 0.13 / 83$ \\
\hline \multicolumn{2}{|c|}{ "Migratory Guilds } \\
\hline Neotropical & $5.99 / \mathbf{0 . 0 1} / 325$ \\
\hline Residents & $0.74 / 0.39 / 20$ \\
\hline Short-Distance & $0.27 / 0.60 / 31$ \\
\hline \multicolumn{2}{|c|}{ Foraging Guilds } \\
\hline Ground gleaners & $0.05 / 0.82 / 127$ \\
\hline Foliage gleaners & $*(\mathrm{n}=6)$ \\
\hline High canopy & $1.84 / 0.17 / 87$ \\
\hline Bark & $*(\mathrm{n}=10)$ \\
\hline Mixed & $3.24 / \mathbf{0 . 0 7 / 1 4 1}$ \\
\hline \multicolumn{2}{|l|}{ Habitat Guilds } \\
\hline Edge & $0.65 / 0.42 / 39$ \\
\hline Interior-Edge & $2.17 / 0.14 / 194$ \\
\hline Forest Interior & $3.45 / \mathbf{0 . 0 6} / 143$ \\
\hline \multicolumn{2}{|l|}{ PIF Species } \\
\hline Red-eyed vireo & $0.33 / 0.57 / 45$ \\
\hline Wood thrush & $0.18 / 0.67 / 72$ \\
\hline
\end{tabular}


Table A-16. Nest survival by distance from edge (DTE) class and edge type, Monongahela National Forest study areas, 1996-1997. Edge classes follow those of Paton (1995). Values followed by the same letter (within an edge type) are not significantly different at $p=0.05$. Asterisk indicates not used in statistical comparisons because of low sample size.

\begin{tabular}{|c|c|c|c|c|c|}
\hline DTE Class & No. Nests & $\begin{array}{l}\text { Incubation } \\
\text { Losses }\end{array}$ & $\begin{array}{l}\text { Brooding } \\
\text { Losses } \\
\end{array}$ & Total Survival & $\begin{array}{l}\text { Variance of } \\
\text { Total Survival } \\
\end{array}$ \\
\hline \multicolumn{6}{|c|}{ Open Canopy Road } \\
\hline $0-25 \mathrm{~m}$ & 43 & 14 & 10 & $0.29 \mathrm{~A}$ & 0.0004 \\
\hline $26-50 \mathrm{~m}$ & 21 & 4 & 5 & $0.36 \mathrm{~B}$ & 0.0010 \\
\hline $51-75 \mathrm{~m}$ & $7 *$ & 3 & 3 & $*$ & $*$ \\
\hline $76-100 \mathrm{~m}$ & 12 & 2 & 2 & $0.36 \mathrm{~B} \mathrm{C}$ & 0.0021 \\
\hline $101-200 \mathrm{~m}$ & 14 & 2 & 3 & $0.44 \mathrm{C}$ & 0.0015 \\
\hline $201-300 \mathrm{~m}$ & $6^{*}$ & 2 & 1 & $*$ & $*$ \\
\hline $301-500 \mathrm{~m}$ & 13 & 1 & 3 & $0.55 \mathrm{D}$ & 0.0015 \\
\hline $501-1000 \mathrm{~m}$ & $7 *$ & 3 & 0 & & \\
\hline $1001-1500 \mathrm{~m}$ & $9 *$ & 0 & 0 & & \\
\hline$>1500 \mathrm{~m}$ & $1 *$ & 0 & 0 & & \\
\hline \multicolumn{6}{|c|}{ Partially-Open Canopy Road } \\
\hline $0-25 \mathrm{~m}$ & 53 & 23 & 7 & $0.21 \mathrm{~A}$ & 0.0003 \\
\hline $26-50 \mathrm{~m}$ & 13 & 4 & 2 & $0.38 \mathrm{~B}$ & 0.0014 \\
\hline $51-75 \mathrm{~m}$ & $1 *$ & 0 & 1 & & \\
\hline $76-100 \mathrm{~m}$ & $2 *$ & 0 & 1 & & \\
\hline $101-200 \mathrm{~m}$ & $4^{*}$ & 2 & 0 & & \\
\hline $201-300 \mathrm{~m}$ & $2 *$ & 0 & 0 & & \\
\hline $301-500 \mathrm{~m}$ & 3* & 0 & 0 & & \\
\hline $501-1000 \mathrm{~m}$ & $5^{*}$ & 1 & 1 & & \\
\hline $1001-1500 \mathrm{~m}$ & $1 *$ & 0 & 0 & & \\
\hline$>1500 \mathrm{~m}$ & $0 *$ & 0 & 0 & & \\
\hline \multicolumn{6}{|l|}{ Clearcut } \\
\hline $0-25 \mathrm{~m}$ & 49 & 11 & 9 & $0.41 \mathrm{~A}$ & 0.0004 \\
\hline $26-50 \mathrm{~m}$ & 15 & 4 & 2 & $0.43 \mathrm{~A}$ & 0.0012 \\
\hline $51-75 \mathrm{~m}$ & $4 *$ & 2 & 1 & & \\
\hline $76-100 \mathrm{~m}$ & $6^{*}$ & 1 & 1 & & \\
\hline $101-200 \mathrm{~m}$ & $9 *$ & 3 & 3 & & \\
\hline \multicolumn{6}{|c|}{ No data beyond $200 \mathrm{~m}$} \\
\hline \multicolumn{6}{|c|}{ Wildlife Opening } \\
\hline $0-25 \mathrm{~m}$ & 14 & 4 & 1 & 0.25 & 0.0015 \\
\hline $26-50 \mathrm{~m}$ & $2 *$ & 0 & 0 & & \\
\hline $51-75 \mathrm{~m}$ & $1 *$ & 0 & 0 & & \\
\hline $76-100 \mathrm{~m}$ & $2 *$ & 0 & 0 & & \\
\hline $101-200 \mathrm{~m}$ & $4 *$ & 1 & 0 & & \\
\hline $201-300 \mathrm{~m}$ & $1 *$ & 1 & 0 & & \\
\hline $301-500 \mathrm{~m}$ & $6^{*}$ & 1 & 2 & & \\
\hline \multicolumn{6}{|c|}{ No data beyond $500 \mathrm{~m}$} \\
\hline \multicolumn{6}{|c|}{ Natural Forest Gap } \\
\hline $0-25 \mathrm{~m}$ & 11 & 4 & 3 & 0.18 & 0.001 \\
\hline $26-50 \mathrm{~m}$ & $0^{*}$ & 0 & 0 & & \\
\hline $51-75 \mathrm{~m}$ & $0^{*}$ & 0 & 0 & & \\
\hline $76-100 \mathrm{~m}$ & $1 *$ & 0 & 0 & & \\
\hline
\end{tabular}


Table A-17. Results of significance tests at multiple scales, effect of site habitat variables on nest survival, Monongahela National Forest study areas, 1996-1997. WCS=Wald's chi-square test statistic. $p$ values $<0.10$ are in bold.

\begin{tabular}{|c|c|c|c|c|c|c|c|c|c|c|c|c|c|}
\hline & \multicolumn{13}{|c|}{ Site Habitat Variable } \\
\hline & $\mathbf{n}$ & $\begin{array}{l}\text { No. Trees } \\
23-38 \mathrm{~cm}\end{array}$ & $\begin{array}{l}\text { No. Trees } \\
>38 \mathrm{~cm} \\
\text { dbh }\end{array}$ & Aspect & Canopy Ht & CAN1 & CAN2 & CAN3 & CAN4 & CAN5 & CAN6 & SDIALL & $\begin{array}{l}\text { Plant } \\
\text { Associatio } \\
\text { n }\end{array}$ \\
\hline & & WCS/p & WCS/p & WCS/p & WCS/p & WCS/p & WCS/p & WCS/p & WCS/p & WCS/p & WCS/p & WCS/p & WCS/p \\
\hline All Birds & 254 & $0.9 / 0.53$ & $0.25 / 0.61$ & $0.6 / 0.44$ & $0.4 / 0.52$ & $0.02 / 0.9$ & $0.1 / 0.75$ & $0.8 / 0.38$ & $0.9 / 0.40$ & $0.71 / 0.4$ & Insuf. data & $0.03 / 0.86$ & $2.54 / 0.11$ \\
\hline \multicolumn{14}{|l|}{ Nesting Guilds } \\
\hline High Canopy & 20 & $2.4 / 0.12$ & $2.41 / 0.12$ & $2.32 / 0.1$ & $2.38 / 0.12$ & $2.37 / 0.12$ & $<0.01 / 0.9$ & $2.40 / 0.12$ & $2.44 / 0.12$ & $2.39 / 0.12$ & Insuf. data & $0.63 / 0.43$ & $0.57 / 0.45$ \\
\hline Low Canopy & 154 & $0.04 / 0.84$ & $2.27 / 0.13$ & $2.14 / 0.14$ & $2.88 / 0.09$ & $1.09 / 0.3$ & $2.88 / 0.09$ & $0.22 / 0.64$ & $<0.01 / 0.9$ & $0.22 / 0.64$ & Insuf. data & $0.46 / 0.50$ & $5.83 / \mathbf{0 . 0 2}$ \\
\hline Shrub Layer & 47 & $0.01 / 0.91$ & $1.36 / 0.24$ & $1.67 / 0.2$ & $0.2 / 0.65$ & $0.68 / 0.41$ & $0.68 / 0.41$ & $1.08 / 0.30$ & $4.00 / \mathbf{0 . 0 4}$ & $1.08 / 0.30$ & Insuf. data & $0.03 / 0.87$ & $4.18 / \mathbf{0 . 0 4}$ \\
\hline \multicolumn{14}{|l|}{$\begin{array}{l}\text { Migratory } \\
\text { Guilds }\end{array}$} \\
\hline Neotropical & 217 & $0.15 / 0.70$ & $0.28 / 0.60$ & $0.91 / 0.34$ & $2.88 / 0.09$ & $0.13 / 0.72$ & $0.03 / 0.86$ & $1.81 / 0.18$ & $0.12 / 0.73$ & $0.96 / 0.33$ & Insuf. data & $0.39 / 0.53$ & $3.7 / \mathbf{0 . 0 5 3}$ \\
\hline Residents & 17 & $0.00 / 0.99$ & $0.00 / 0.99$ & $0.002 / 0.9$ & $<0.01 / 0.9$ & $<0.01 / 0.9$ & $0.00 / 0.99$ & $<0.01 / 0.9$ & $<0.01 / 0.9$ & $0.92 / 0.92$ & Insuf. data & $0.01 / 0.9$ & $0.004 / 0.9$ \\
\hline \multicolumn{14}{|l|}{ Foraging Guilds } \\
\hline $\begin{array}{l}\text { Ground } \\
\text { gleaners }\end{array}$ & 87 & $0.18 / 0.67$ & $0.07 / 0.79$ & $4.72 / \mathbf{0 . 0 3}$ & $6.49 / \mathbf{0 . 0 1}$ & $3.13 / \mathbf{0 . 0 8}$ & $1.64 / 0.20$ & $1.66 / 0.20$ & $<0.01 / 0.9$ & $<0.01 / 0.9$ & Insuf. data & $2.24 / 0.14$ & $0.03 / 0.86$ \\
\hline $\begin{array}{l}\text { Foliage } \\
\text { gleaners }\end{array}$ & 51 & $0.2 / 0.66$ & $0.20 / 0.65$ & $6.06 / \mathbf{0 . 0 1}$ & $6.17 / \mathbf{0 . 0 1}$ & $<0.01 / 0.9$ & $1.33 / 0.27$ & $1.60 / 0.21$ & $0.03 / 0.87$ & $0.11 / 0.74$ & Insuf. data & $0.07 / 0.79$ & $2.9 / 0.09$ \\
\hline Bark & 13 & $<0.01 / 0.9$ & $<0.01 / 0.9$ & $<0.01 / 0.9$ & $<0.01 / 0.9$ & $<0.01 / 0.9$ & $<0.01 / 0.9$ & $<0.01 / 0.9$ & $<0.01 / 0.9$ & $<0.01 / 0.9$ & Insuf. data & $<0.01 / 0.9$ & $<0.01 / 0.9$ \\
\hline Mixed & 98 & $0.10 / 0.75$ & $0.30 / 0.59$ & $1.54 / 0.22$ & $1.03 / 0.32$ & $5.56 / \mathbf{0 . 0 2}$ & $0.49 / 0.48$ & $2.17 / 0.14$ & $0.64 / 0.42$ & $1.83 / 0.18$ & Insuf. data & $1.54 / 0.21$ & $1.48 / 0.22$ \\
\hline \multicolumn{14}{|l|}{ Habitat Guilds } \\
\hline Edge & 21 & $1.13 / 0.29$ & $1.24 / 0.27$ & $0.73 / 0.39$ & $0.07 / 0.79$ & $1.09 / 0.30$ & $1.08 / 0.30$ & $0.77 / 0.38$ & $1.41 / 0.24$ & $0.95 / 0.33$ & Insuf. data & $0.20 / 0.66$ & $1.10 / 0.30$ \\
\hline Interior-Edge & 134 & $0.97 / 0.33$ & $0.01 / 0.90$ & $0.01 / 0.91$ & $3.37 / \mathbf{0 . 0 7}$ & $1.62 / 0.20$ & $0.10 / 0.76$ & $0.72 / 0.39$ & $0.19 / 0.66$ & $0.35 / 0.55$ & Insuf. data & $0.04 / 0.85$ & $5.81 / \mathbf{0 . 0 2}$ \\
\hline Interior & 97 & $1.12 / 0.29$ & $0.21 / 0.65$ & $5.51 / 0.02$ & $6.70 / \mathbf{0 . 0 1}$ & $6.54 / 0.01$ & $0.14 / 0.70$ & $5.04 / 0.02$ & $0.08 / 0.77$ & $4.78 / \mathbf{0 . 0 3}$ & Insuf. data & $4.89 / \mathbf{0 . 0 3}$ & $0.24 / 0.62$ \\
\hline
\end{tabular}


Table A-18. Site habitat effects on clutch size by bird group. Table includes only variables significant at $\mathbf{p}<0.10$ and models with $\mathbf{r} 2$ at least 0.20 .

\begin{tabular}{|l|l|l|l|}
\hline \hline Bird group & Variable & $\begin{array}{l}\text { Sig. } \\
\text { Level }\end{array}$ & Model $\mathrm{r}^{2}$ \\
\hline $\begin{array}{l}\text { Bark } \\
\text { foragers }\end{array}$ & Trees $>38 \mathrm{~cm}$ & 0.04 & 0.70 \\
\hline $\begin{array}{l}\text { Forest } \\
\text { interior }\end{array}$ & Canopy $>24 \mathrm{~m}$ & 0.0004 & 0.22 \\
\hline & Canopy 12-18m & 0.03 & \\
\hline \hline $\begin{array}{l}\text { Shrub } \\
\text { nesters }\end{array}$ & Layer 0.5-3m & 0.0055 & 0.23 \\
\hline & Layer 12-18 m & 0.06 & \\
\hline & Plant association & 0.02 & \\
\hline \hline
\end{tabular}




\section{Vita}

Thomas Eugene DeMeo

Positions Held:

1999-Present Pacific Northwest Regional Ecologist, USDA Forest Service

1998-1999 Wildlife Biologist, Resources Technical Support Team, NRIS Terra, USDA Forest Service

1993-1998 Ecologist, Monongahela National Forest, USDA Forest Service

1987-1993 Ecologist, Ketchikan Area, Tongass National Forest, USDA Forest Service

1982-1984 U.S. Peace Corps Volunteer, Botswana, Southern Africa

1980-1982 U.S. Peace Corps Volunteer, Ghana, West Africa

Degrees Earned:

1980 B.S. Forest Science, Pennsylvania State University, Silviculture Emphasis

1987 M.S. Forest Science, Oregon State University, Minor in Integrated Agriculture

1999 Ph.D. Forest Resources Science, West Virginia University, Wildlife Emphasis

Date of Birth: March 26, 1958

Married to Julie A. Concannon since 1984, with two chldren: Patrick (age 10) and Grace (age 5). 